INTERNATIONAL MONETARY FUND
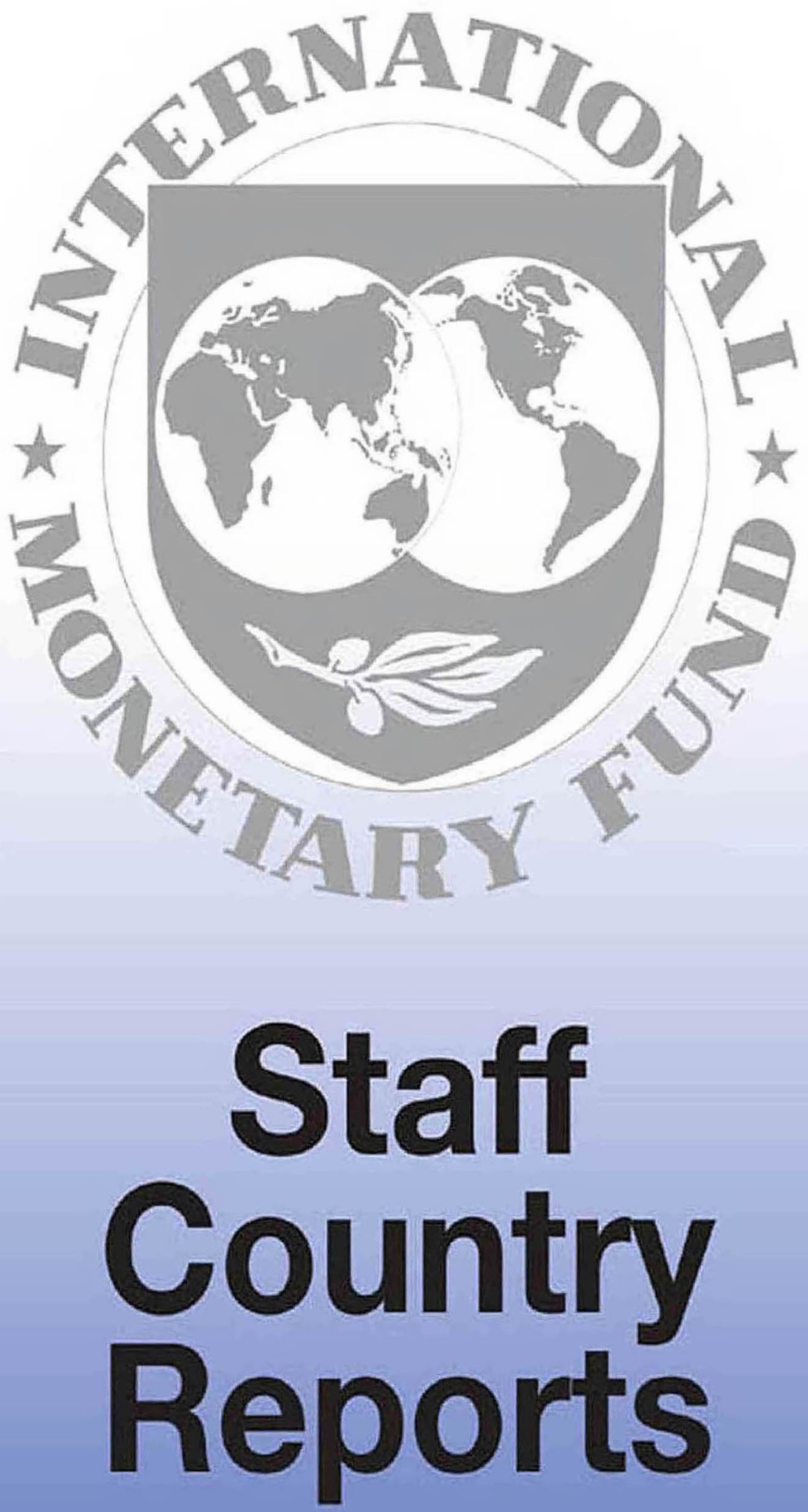


\section{Nigeria: Publication of Financial Sector Assessment Program Documentation- Detailed Assessment of Observance of Insurance Core Principles}

This Detailed Assessment of Observance of Insurance Core Principles for Nigeria was prepared by a staff team of the International Monetary Fund as background documentation for the periodic consultation with the member country. It is based on the information available at the time it was completed in May, 2013. The views expressed in this document are those of the staff team and do not necessarily reflect the views of the government of Nigeria or the Executive Board of the IMF.

The policy of publication of staff reports and other documents by the IMF allows for the deletion of market-sensitive information.

Copies of this report are available to the public from

International Monetary Fund • Publication Services

$70019^{\text {th }}$ Street, N.W. $\bullet$ Washington, D.C. 20431

Telephone: (202) 623-7430 • Telefax: (202) 623-7201

E-mail: publications@imf.org Internet: http://www.imf.org

\section{International Monetary Fund \\ Washington, D.C.}


Financial Sector Assessment Program Update

\section{NiGERIA}

INSURANCE CORE PRINCIPLES

\section{DETAILED ASSESSMENT OF OBSERVANCE}

MAY 2013

INTERNATIONAL MONETARY FUND

MONETARY AND CAPITAL MARKETS DEPARTMENT
THE WORLD BANK FinANCIAL SECTOR Vice PRESIDENCY Africa REgION Vice PRESIDENCY 
Glossary

Executive Summary

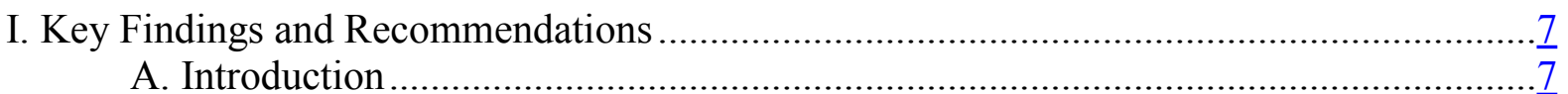

B. Information and Methodology Used for Assessment.......................................... $\frac{7}{7}$

C. Overview_-Institutional and Market Structure .................................................... $\frac{8}{7}$

D. Preconditions for Effective Insurance Supervision........................................17

E. Main Findings............................................................................... 19

F. Recommendations and the Authorities' Responses........................................ $\underline{23}$

II. Detailed Assessment .....................................................................................

Tables

1. Total Assets of Insurance Firms, 2006-2011 .........................................................

2. Gross Written Premium, 2007-2011 .................................................................... $\frac{10}{12}$

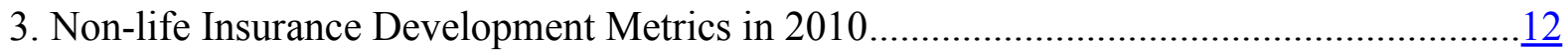

4. Foreign Ownership of Insurers in 2010 ...............................................................

5. Market Share of the Top Five and Ten Non-life Insurers, 2006-2010 ........................... $\frac{14}{14}$

6. Market Share of the Top Ten Non-life Insurers, 2010 ................................................14

7. Market Share of the Top Five and Ten Life Insurers, 2006-2010...................................

8. Market Share of the Top Ten Life Insurers, 2010 ................................................

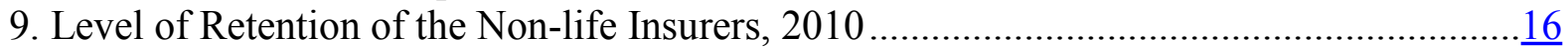

10. Level of Retention of the Life Insurers, 2006-2010 .................................................

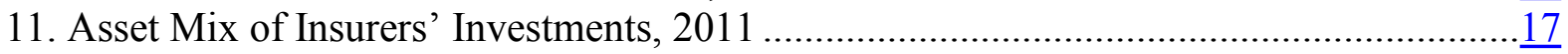

12. Market Capitalization of Listed Insurers, July 2012 .................................................

13. Summary of Observance of the Insurance Core Principles ..........................................22

14. Recommendations to Improve Observance of ICPs ............................................... $\frac{23}{30}$

15. Detailed Assessment of Observance of the Insurance Core Principles .......................... $\underline{30}$

Figures

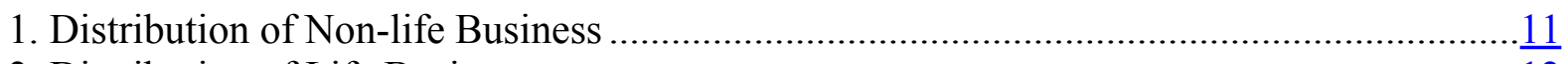

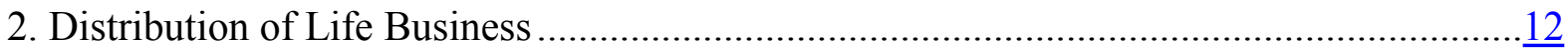




\section{GLOSSARY}

AML

ANAN

CBN

CFI

CFT

CGCG

CIIN

FATF

FRC

FSAP

IA

IAIS

ICAN

ICP

IFRS

IMF

KYC

MAVICS

$\mathrm{MoU}$

NA

NAICOM

NFIU

N

OPEC

$\mathrm{RM}$

ROSC
Anti-Money Laundering

Association of National Accounts of Nigeria

Central Bank of Nigeria

Commissioner for Insurance

Combating the Financing of Terrorism

Code of Good Corporate Governance

Chartered Insurance Institute of Nigeria

Financial Action Task Force

Financial Reporting Council

Financial Sector Assessment Program

Insurance Act of 2003

International Association of Insurance Supervisors

Institute of Chartered Accountants of Nigeria

Insurance Core Principles

International Financial Reporting Standards

International Monetary Fund

Know-your-clients

Motor Accident Victims Insurance Compensation Scheme

Memorandum of Understanding

National Insurance Commission Act of 1997

National Insurance Commission (Nigeria)

Nigerian Financial Intelligence Unit

Nigeria Nairas

Oil Producing and Exporting Countries

Risk Management

Report on the Observance of Standards and Codes 


\section{EXECUTIVE SUMMARY}

1. Insurance activity in Nigeria is regulated by two Acts and supervised by the National Insurance Commission. The Insurance Act, No. 1 of 2003 governs the licensing and the operation of insurers, reinsurers, intermediaries, and other providers of related services. The National Insurance Commission Decree, No. 1 of 1997 established the National Insurance Commission (NAICOM) as the supervisory institution with the power of inspection, remedial and enforcement actions, and composition of fines. NAICOM is funded by industry levy and government grants, 50 percent of which is for operational purposes, 30 percent for upgrading industry capacity and 20 percent for industry development and compensation. Insurers must be established as limited liability companies under the Companies and Allied Matters Act, 1990.

\section{The insurance sector is an underdeveloped part of the Nigerian financial sector} with assets less than 2 percent of GDP. Assets of the life business are about half of the assets of the non-life sector, reflecting the low level of activity in savings and investment insurance products. In terms of gross written premium, the insurance sector grew at an average rate of 23 percent from 2001 to 2010 but remains very small. The total premium income was $\$ 201$ billion in $2010^{1}$, representing 0.7 percent of GDP or only just above a tenth of the average penetration of the OECD countries. The gross written premium is estimated to be 232 billion in 2011 .

\section{The substantial increase in the minimum capital requirements in 2007 led to a} reduction from 104 to 60 insurers in 2008 . Further market consolidation, albeit at a lower scale, is expected in the coming months as a result of the banking regulation that requires banks to divest their non-banking activities, including insurance, by April 2012. ${ }^{2}$ Non-life insurance is more developed than life insurance. All non-life lines of business are offered, and their market share is balanced between motor, marine and aviation and property. Traditional life insurance is offered, of which around 70 percent corresponds to group life. However, modern life products, such as critical illness or inflation indexed benefits, are not readily available.

\section{NAICOM has made a lot of effort over the past five years to improve the} regulatory environment. Following the recapitalization of insurers and reinsurers in 2007 aimed at eliminating unprofitable and insolvent companies, NAICOM has upgraded its regulatory requirements, including a voluntary code on corporate governance, operational guidelines, risk management framework, KYC and AML/CFT requirements, and the adoption of IFRS. When fully implemented, these initiatives will significantly improve the

\footnotetext{
${ }^{1} 1 \mathrm{USD} \$=157.5 \mathrm{~N}$ as august 25, 2012.

${ }^{2}$ At the date of the assessment, the divesture was largely completed, except one or two banks that require additional time to restructure. However, new statistics are not yet available post-divesture.
} 
regulatory environment for the industry. A critical success factor is to provide NAICOM officers with the necessary technical knowledge and supervisory skills suitable for the new regime.

\section{The legal status of the guidelines issued by NAICOM should also be clarified.}

NAICOM has the power under the law to make regulations and issue guidelines. The issuance of regulations is subject to the minister's approval while the issuance of guidelines is not. NAICOM has issued a number of significant prudential requirements in the form of guidelines, such as minimum capital, technical provisions, investment limits and risk management. It is important to have legal certainty on the level of enforceability of the guidelines.

\section{The solvency regime, valuation and the reserve requirements need to be} upgraded to capture the nature of risk inherent in each insurer. Current technical provisions and solvency margins are factor-based without regard to the nature of risks. The basis of estimating liabilities is left to the insurers or actuaries in the case of life business. The regime is in urgent need of revamping to become commensurate with the intended move toward a risk-based supervision framework.

7. Poor accounting and auditing practices results in supervisors spending too much time in verifying the accuracy of financial data. Supervisors spend more time verifying data than analyzing them. This not only hinders effective supervision, but also timely disclosure of information to policyholders and the market in general. NAICOM should collaborate with the FRC to improve the reliability of the audited financial statements, so that supervisors are able to focus more on both quantitative analysis and qualitative aspects of supervision. To promote proper governance, NAICOM should take insurers and directors to task for submitting inaccurate information.

\section{Given the existing premium volume, the high capital requirements present a} challenge to the attractiveness of the sector. Minimum capital requirements are high compared to other developing countries. For instance, countries under a Solvency I regime usually require for insurers a minimum capital of between US\$ 4 and 10 million. Current Nigerian minimum capital requirements are three to six times higher. Except for the largest insurers, the return on equity is low as a result of low premium volume and high capital base. While the high capital is sensible to ensure professionalism in the industry, there is a need to study the appropriateness of the capital requirement to balance risk, return and market development. The minimum paid-up capital should be evaluated when introducing risk-based capital so that capital adequacy will reflect the risks that the insurer takes on.

9. Several insurers are in urgent need of evaluating their business viability. Some insurers need capital injection to comply with solvency requirements. Few insurers have made profits for 2011 according to the unofficial numbers available to NAICOM as of September 2012. The drop in stock prices of over 60 percent since 2007 has affected 
investments in the insurance sector resulting in several publicly traded insurers losing all share premia and are currently trading at nominal value or the minimal share value required for listing.

\section{Government is actively pursuing policy to address the need for the sector to} grow; however, enforcement of compulsory insurance is suboptimal. There are six classes of compulsory insurance but enforcement is weak. More effective enforcement will provide a substantial stable premium income for the industry. NAICOM recognizes this and has been working with other relevant authorities to strengthen enforcement. Under this initiative, a motor insurance database will be launched in the coming months, aiming to stamp out rampant fake motor insurance certificates, by providing a quick and easy way for the enforcement agency and customers to verify the authenticity of insurance certificates.

\section{Sufficient investment instruments exist to cover current short term insurance} liabilities, but, as the annuities and long term insurance markets develop, there will be a need for longer term investment instruments. Both life and non-life companies have similar investment portfolios. The asset composition of insurers consists of short-term money market and bank deposits (30 percent), stock and private debentures (another 30 percent) and real estate, loans and government paper ( 40 percent). The need for liquid assets reflects the short duration of the existing liabilities in both non-life and life. As the occupational pension system matures, an increase in annuities is expected that will require long term investment instruments that currently are not readily available.

\section{Reinsurance is influenced by market development considerations, at the cost of} possible loss of knowledge transfer. Direct insurers are required to retain at least 5 percent of the risks to discourage fronting of business. Reinsurance with foreign reinsurers requires NAICOM approval, subject to the insurer demonstrating that it has exhausted local reinsurance capacity. Insurers must satisfy the mandatory cession to Africa Re before they may seek coverage with other reinsurers. Mandatory cessions, preferential tax treatment and supervisory exemption create an unlevel playing field and hinder competition. As local insurers could benefit from the transfer of technical know-how from foreign reinsurers, the exclusive use of local reinsurers for certain types of business should be reconsidered.

\section{Consumer protection needs to be treated with high priority. As the compulsory} insurance is enforced, the cost of intermediation of compulsory insurance and the purchase of retirement annuities need to be addressed to improve efficiency of the market. NAICOM should improve the disclosure standards, requiring intermediaries to disclose their capacity to act (whether as agent or broker), their financial interest in the policy, and any conflict of interest that might affect their recommendation of products. For annuities, electronic bidding models like the one existing in Chile would benefit the annuitants by enhanced cost transparency and reducing intermediation costs. 


\section{KEY FINDINGS AND RECOMMENDATIONS}

\section{A. Introduction}

\section{This assessment provides an update on the significant regulatory and} supervisory development in the Nigerian insurance sector since 2001. Nigeria undertook an initial Financial Sector Assessment Program (FSAP) in December 2001, which included a review of the structure of Nigeria's insurance market and the supervisory framework and approach. Nigeria has also undertaken reviews of its observance of international accounting and auditing standards (2004 and 2011), and corporate governance (2008).

\section{The Nigerian authorities have taken steps to address a number of weaknesses} identified in the 2001 FSAP. The insurance industry has gone through a significant consolidation, resulting in a decline of number of insurers and reinsurers from 118 in 2001 to 61 in 2012. Further market restructuring is expected as a result of a November 2010 banking regulation requiring all banks to divest non-banking business, including insurance and insurance broking, by April 2012. A new Insurance Act came into effect in 2003, supplemented by recapitalization guidelines in 2005, Code of Good Corporate Governance (CGCG) in 2009, Operational Guidelines in 2011 for insurers, reinsurers and intermediaries, and anti-money laundering (AML) regulations, know-your-clients (KYC) procedures and risk management guidelines in 2012. Insurers are required to adopt the International Financial Reporting Standards (IFRS) from 2012.

16. The current assessment was conducted by Dr. Rodolfo Wehrhahn, staff of the International Monetary Fund (IMF) and Mrs. Mimi Ho, Insurance Supervision Advisor contracted by the IMF, during September 9-19, 2012.

\section{B. Information and Methodology Used for Assessment}

\section{The assessment was benchmarked against the Insurance Core Principles (ICPs)} issued by the International Association of Insurance Supervisors (IAIS) in October 2011. The ICPs apply to all insurers whether private or government-controlled. Specific principles apply to the supervision of intermediaries. The ICPs are presented according to a hierarchy of supervisory material:

a) ICP statements are the highest level and prescribe the essential elements that must be met in order to achieve observance.

b) Standards which are linked to specific ICP statements and set out key high level requirements that are fundamental to the implementation of the ICP statement.

c) Guidance material provides detail on how to implement an ICP statement or standard. 
18. The rating reflects the level of observance for each ICP in the regulatory and supervisory approach with due regard to proportionality. Each ICP is rated in terms of the level of observance as follows:

- Observed: where all the standards are observed except for those that are considered not applicable. For a standard to be considered observed, the supervisor must have the legal authority to perform its duties and must exercise this authority to a satisfactory level.

- Largely observed: where only minor shortcomings exist, which do not raise any concerns about the authorities' ability to achieve full observance.

- $\quad$ Partly observed: where, despite progress, the shortcomings are sufficient to raise doubts about the authorities' ability to achieve observance.

- Not observed: where no substantive progress toward observance has been achieved.

- $\quad$ Not Applicable: when the standards are considered to be not applicable.

19. The assessment is based solely on the laws, regulations and other supervisory requirements and practices that are in place at the time of the assessment. Ongoing regulatory initiatives, such as proposed legislation, are noted by way of additional comments. The authorities provided a comprehensive self-assessment and other pertinent information such as reports, studies, public statements, websites, and guidelines. The assessors also met a number of Nigerian insurers, industry associations and other stakeholders.

20. The assessors are grateful to the authorities for their full cooperation, thoughtful logistical arrangements and coordination of various meetings with insurers and industry associations. In-depth discussions with and briefings by officials from NAICOM facilitated a robust and meaningful assessment of the Nigerian regulatory and supervisory regime for the insurance sector.

\section{Overview-Institutional and Market Structure}

\section{Institutional framework and arrangements}

21. The insurance activity is regulated by two main Acts and supervised by NAICOM. The Insurance Act, No. 1 of 2003 (IA) governs the licensing and the operation of insurers, reinsurers, intermediaries and other providers of related services. The IA superseded the Insurance Decree, No. 2 of 1997. Insurers must be established as limited liabilities companies under the Companies and Allied Matters Act, 1990, with the exception of the National Insurance Corporation of Nigeria (NICON) and Nigeria Reinsurance Corporation. The National Insurance Commission Decree, No. 1 of 1997 (NA) established NAICOM as the supervisory institution with power of inspection, remedial and enforcement actions, and 
composition of fines. The Governing Board of NAICOM comprises 11 individuals representing public interest and relevant public and professional entities. Functions of NAICOM include licensing; approval of premium rates, commission rates and policy terms and conditions; and protect policyholders and beneficiaries to insurance contracts.

\section{NAICOM is funded by industry levy and government grants, 30 percent of} which is earmarked for upgrading industry capacity and 20 percent earmarked for industry development and compensation. Approximately 20 percent of NAICOM's revenue is from the federal government (before transfers to the earmarked funds), and the remaining from (a) 1 percent levy on premiums, commissions and fees, (b) fees and penalties, (c) investment income, and (d) gifts and endowments. The earmarked education fund provides funding to insurance educational institutions, while the development fund finances initiatives to develop the insurance market and provide compensation to consumers.

23. NAICOM has strengthened its supervision and enforcement efforts. In the past five years, NAICOM has stepped up its vigilance in ensuring the accuracy of financial information and enforcing compliance. To give effect to the requirements in the IA, NAICOM has issued a number of code and guidelines on minimum capital, risk management, operations, corporate governance, AML and KYC. It has also mandated the adoption of IFRS from 2012. It has drawn up a roadmap to move toward a risk-based supervisory regime by the end of 2013.

\section{NAICOM launched a three-year market development plan in August 2009 to} increase market capacity, improve market efficiency and increase consumer protection. The Market Development and Restructuring Initiative (MDRI) aims to deepen and grow the insurance market by focusing on four issues:

- $\quad$ Enforcement of compulsory insurance. ${ }^{3}$

- $\quad$ Sanitization and modernization of insurance agency system.

- Wiping-out of fake insurance institutions.

- Introduction of risk-based supervision.

To create public awareness of the compulsory insurance, NAICOM has conducted several road shows in three geo-political zones in the north-west, north-east and south-west, and

${ }^{3}$ There are six compulsory insurance coverages under various legislations. They are:

a. Group life insurance in line with the Pencom Act 2004

b. Employers liability in line with the Workmen's Compensation Act 1987

c. Buildings under construction - Section 64 of the Insurance Act 2003

d. Occupiers liability insurance - Section 65 of the Insurance Act 2003

e. Motor third party insurance - Section 68 of the Insurance Act 2003

f. Health care professional indemnity insurance - under Section 45 of the NHIS Act 1999 
distributed several free factsheets and leaflets to the public. While MDRI has not achieved its target premium level of $\$ 1$ trillion in 2012, it has made progress in addressing each of the issues.

25. Improvements have been made to the mandatory motor third party liability with the introduction of a safety net. A Motor Accident Victims Insurance Compensation Scheme (MAVICS) was launched by NAICOM in 2008, providing compensation of third parties permanently disabled or killed by uninsured or unidentified vehicles. MAVICS is funded by the security and development fund.

\section{Market structure and industry performance}

26. The insurance sector is an underdeveloped part of the Nigerian financial sector with less than 2 percent of GDP in assets. Assets of the life business are about half of the assets of the non-life sector reflecting a low level of savings and investment insurance products (see Table 1). In terms of gross written premium, the total sector grew at an average rate of 23 percent from 2001 to $2010^{4}$ but remains very small with a total premium income of N192 billion, representing 0.7 percent of GDP in 2010. The gross written premium is estimated to be $\$ 232$ billion in 2011 (see Table 2).

Table 1. Nigeria: Total Assets of Insurance Firms, 2006-11

\begin{tabular}{|c|c|c|c|c|c|c|}
\hline millions & 2006 & 2007 & 2008 & 2009 & 2010 & 2011 \\
\hline Non-Life & 219.09 & 302.26 & 375.01 & 388.35 & 391.74 & 417.35 \\
\hline Life & 88.46 & 125.23 & 183.72 & 198.11 & 193.27 & 204.55 \\
\hline Total & 307.55 & 427.49 & 558.73 & 586.46 & 585.01 & 621.90 \\
\hline As a \% of GDP & 1.64 & 2.04 & 2.27 & 2.32 & 1.98 & 1.65 \\
\hline
\end{tabular}

Source: NAICOM.

Table 2. Nigeria: Gross Written Premium, 2007-2011

\begin{tabular}{|l|l|c|c|c|c|c|}
\hline \multicolumn{2}{|c|}{ Dillions } & $\mathbf{2 0 0 7}$ & $\mathbf{2 0 0 8}$ & $\mathbf{2 0 0 9}$ & $\mathbf{2 0 1 0}$ & $\mathbf{2 0 1 1}$ \\
\hline \multirow{5}{*}{ Non-Life } & Motor & 25.77 & 38.70 & 44.13 & 42.44 & 46.16 \\
\cline { 2 - 7 } & Fire & 11.46 & 17.45 & 19.53 & 23.25 & 25.71 \\
\cline { 2 - 7 } & Accident & 16.57 & 23.21 & 25.92 & 26.93 & 31.30 \\
\cline { 2 - 7 } & Oil \& Gas & 0 & 19.25 & 35.06 & 27.45 & 34.89 \\
\cline { 2 - 7 } & Marine & 10.76 & 16.51 & 17.19 & 20.13 & 22.34 \\
\cline { 2 - 7 } & W/Comp & 0.99 & 1.00 & 0.90 & 1.45 & 0.85 \\
\cline { 2 - 7 } & Misc. & 23.56 & 10.34 & 10.74 & 7.4 & 14.40 \\
\cline { 2 - 7 } & Total non-life & 89.10 & 126.47 & 142.74 & 149.04 & 175.63 \\
\hline Life & 16.27 & 30.74 & 36.83 & 43.00 & 57.07 \\
\hline Total & 105.37 & 157.21 & 179.57 & 192.04 & 232.70 \\
\hline
\end{tabular}

Source: NAICOM.2011 provisional numbers.

\footnotetext{
${ }^{4}$ Source: Nigerian Insurance Association Digest 2011
} 
27. The substantial increase in the minimum capital requirements in 2007 led to a reduction in the number of insurers from 104 to 60 in 2008. Currently, the industry is served by 32 non-life insurers, 17 life insurers, 10 composite insurers and two reinsurers. There are 1,737 registered agents, 542 brokers (excluding 32 suspended brokers) and 48 loss adjusters. Further market consolidation, albeit at a lower scale, is expected in the coming months as a result of the banking regulation that required banks to divest their non-banking activities including insurance by April 2012.

28. Non-life insurance is more developed compared with life insurance. The non-life insurance sector is about three times the size of the life insurance sector. In terms of world ranking, the Nigerian non-life insurance industry ranked at $57^{\text {th }}$ and the life insurance industry ranked at $63^{\text {rd }}$ in 2010. All non-life lines of business are offered. Motor, marine and aviation, and property are the dominant lines. Around 70 percent of the life business is the compulsory group life. More sophisticated life products such as critical illness or inflationindexed benefits are not readily available.

Figure 1. Nigeria: Distribution of Non-life Business

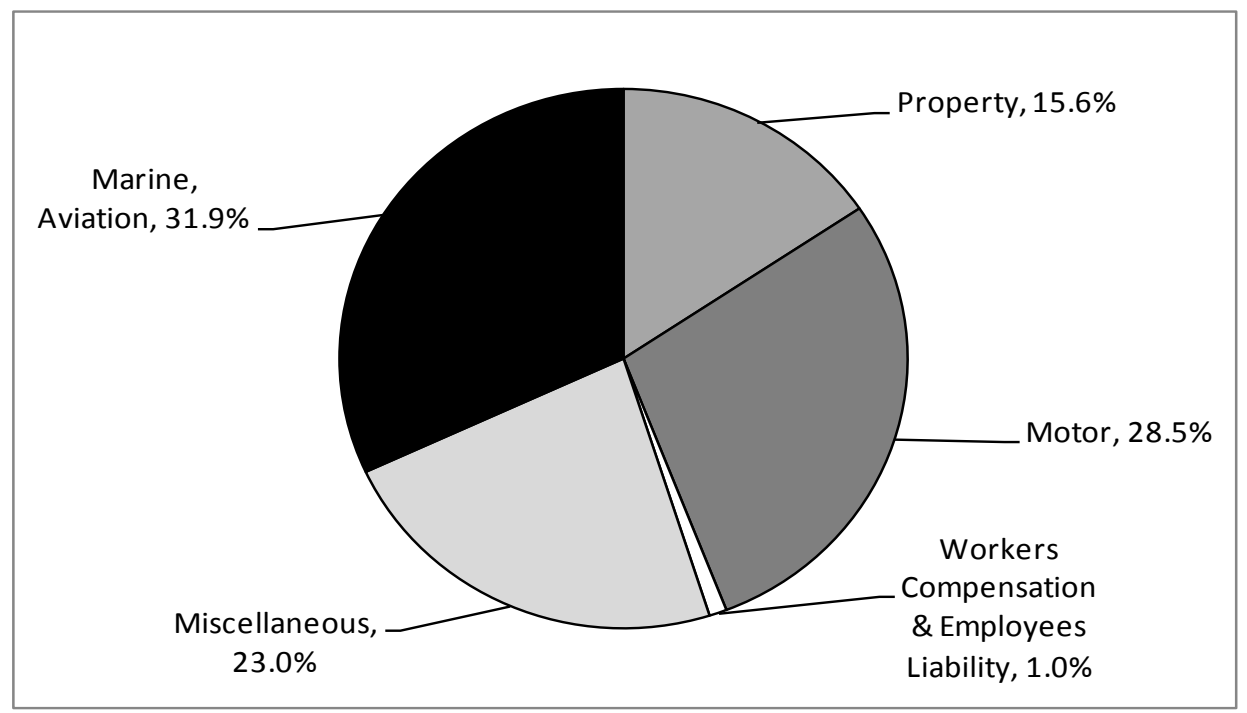

Source: NAICOM, and Axco Global Statistics. 
Figure 2. Nigeria: Distribution of Life Business

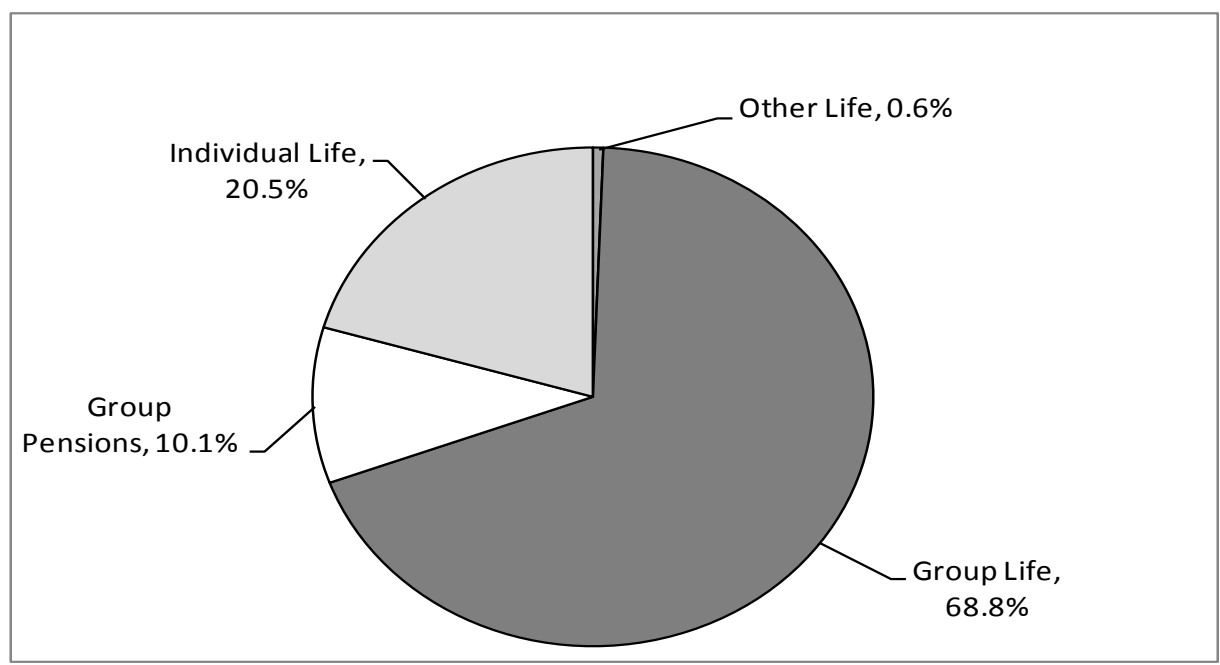

Source: NAICOM, and Axco Global Statistics.

29. Insurance penetration is very low. Non-life insurance penetration is around onehalf percent, or only one-seventh of the average penetration of the OECD countries in 2010. Life insurance penetration is even lower at around 0.2 percent. This comparison does not improve when a better measurement of insurance utilization is used, which takes into consideration dependence on the economic development of the country as well as the benchmarked insurance penetration against the world insurance penetration average (BMIP) for the non-life sector. The Nigerian BMIP value indicates that the insurance industry is underdeveloped with only 43 percent of the world average insurance penetration at the Nigerian 2010 GDP per capita level, placing Nigeria at the bottom of comparable countries, with the exception of Egypt.

Table 3. Nigeria: Non-life Insurance Development Metrics in 2010

\begin{tabular}{lrcr}
\hline & $\begin{array}{l}\text { Non- Life } \\
\text { Insurance } \\
\text { penetration }\end{array}$ & $\begin{array}{l}\text { Penetration as a } \\
\text { percentage of OECD } \\
\text { average penetration }\end{array}$ & BMIP \\
\hline Angola & 0.91 & $27 \%$ & 58.99 \\
Egypt & 0.39 & $12 \%$ & 30.18 \\
Ghana & 0.56 & $17 \%$ & 47.75 \\
Kenya & 1.58 & $46 \%$ & 142.75 \\
Morroco & 1.62 & $48 \%$ & 124.09 \\
Nigeria & $\mathbf{0 . 5 1}$ & $\mathbf{1 5 \%}$ & $\mathbf{4 2 . 8 8}$ \\
South Africa & 1.87 & $55 \%$ & 96.82 \\
\hline
\end{tabular}

Source: Sigma and IMF staff calculations. BMIP is the insurance penetration benchmarked against the world average insurance penetration. The benchmark was developed by the average of the world insurance penetration calculated using data from 1980 to 2006 for 95 countries. 
Regulation limits foreign ownership of insurers to 40 percent, but that limit appears to be flexible. The table below indicates foreign ownership above the 40 percent limit.

Table 4. Nigeria: Foreign Ownership of Insurers in 2010

\begin{tabular}{|l|l|l|l|}
\hline & Insurance Company & Owner \& Percent Shareholding & Country of Origin \\
\hline 1 & $\begin{array}{l}\text { Old Mutual Insurance } \\
\text { Company }\end{array}$ & $\begin{array}{l}\text { Mutual \& Federal Insurance } \\
\text { Company, 70 percent }\end{array}$ & South Africa \\
\hline 2 & ADIC Insurance & $\begin{array}{l}\text { NSIA Participations S.A Holdings, } \\
96.15 \text { percent }\end{array}$ & Cote d'Ivoire \\
\hline 3 & $\begin{array}{l}\text { Guaranty Trust Assurance } \\
\text { (now Mansard Insurance) }\end{array}$ & Assur Africa Holding, 67.68 percent & $\begin{array}{l}\text { UK/German Private } \\
\text { Equity }\end{array}$ \\
\hline 4 & Prestige Insurance & $\begin{array}{l}\text { The New India Assurance Company } \\
\text { Limited, 40.04 percent }\end{array}$ & India \\
\hline 5 & Continental Re & Local and foreign investors & US private equity \\
\hline
\end{tabular}

Source: NAICOM.

30. Government ownership has gone down but it remains in agriculture insurance. Following its policy of privatization and commercialization of public enterprises, the federal government has reduced its holdings in NICON Insurance and Nigeria Re from 100 percent down to a minority shareholding. However, the federal government still owns 100 percent of Nigerian Agricultural Insurance Corporation.

\section{Minimum capital requirements are high compared with other developing} countries. NAICOM has drastically raised the minimum capital in 2007 to eliminate unprofitable and insolvent insurers. For example, the minimum capital for non-life insurers was raised from $\$ 200$ million to $\$ 3$ billion. Countries under a Solvency I regime usually require for insurers a minimum capital between US\$4 and 10 million. Current Nigerian minimum capital requirements are as follows:

- $\quad$ Non-life companies: $\$ 3$ billion (US\$19.14 million).

- $\quad$ Life companies: $\$ 2$ billion (US\$12.76 million).

- $\quad$ Composite companies: $\$ 5$ billion (US\$31.9 million).

- $\quad$ Reinsurance companies: 10 billion (US\$63.8 million).

- Brokers are not required to have a minimum capital.

32. The solvency regime and the technical reserve requirements need to be upgraded to reflect the nature of risks. Assets for solvency purposes are on "admissible" basis, excluding unpaid premiums, intangible assets, foreign investments and investments in excess of prescribed investments limits. Technical provisions for non-life business comprise estimated unexpired risk, outstanding claims and 10 percent of outstanding claims as incurred but not reported claims (IBNR). Technical provisions for life business are the 
amounts certified by the actuary as sufficient. Non-life insurers are required to keep a minimum solvency margin (that is, admissible assets less liabilities) of 15 percent of net premium, but not less than the minimum paid-up capital. There is no solvency margin requirement for life business.

33. The non-life insurance market is competitive, with only two companies having market shares of over 5 percent. Leadway and Custodian and Allied each having a market share close to 10 percent by gross written premium are followed by eight insurers each having similar market shares below 5 percent. The top 10 insurers account for 50 percent of the market.

Table 5. Nigeria: Market Share of the Top Five and Ten Non-life Insurers, 2006-2010

\begin{tabular}{|l|c|c|c|c|c|}
\hline & 2006 & 2007 & 2008 & 2009 & 2010 \\
\hline Top 5 companies (\%) & 41.7 & 34.4 & 33.5 & 36.2 & 33.8 \\
\hline Top 10 companies (\%) & 56.0 & 50.3 & 49.8 & 51.2 & 50.6 \\
\hline
\end{tabular}

Source: NAICOM.

Table 6. Nigeria: Market Share of the Top Ten Non-life Insurers, 2010 (In Million)

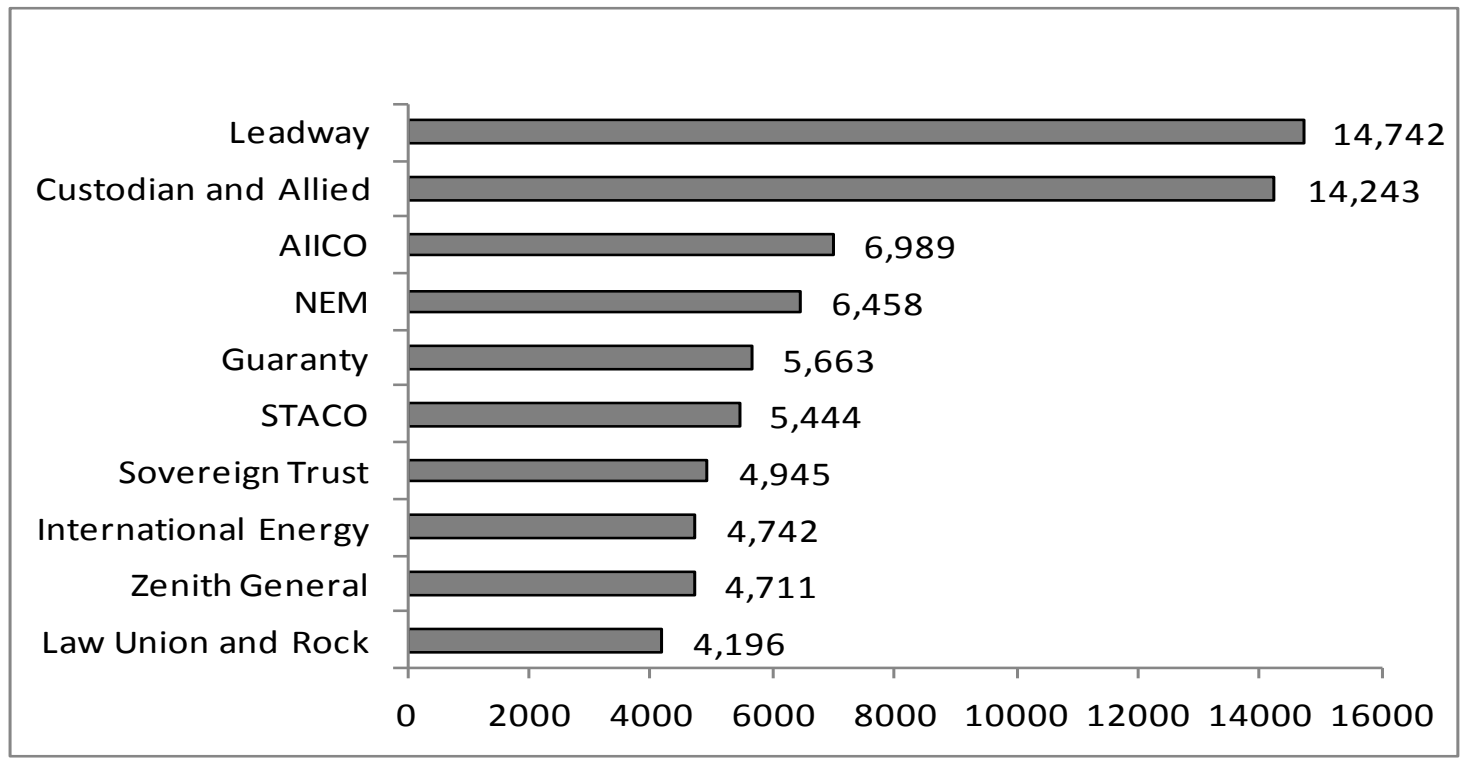

Source: NAICOM.

34. The life insurance market is dominated by one insurer holding around 20 percent market share. AIICO, a locally owned public company, holds around 20 percent market share. The next nine largest life insurers account for another 50 percent of the market. 
Table 7. Nigeria: Market Share of the Top Five and Ten Life Insurers, 2006-2010

\begin{tabular}{|l|c|c|c|c|c|}
\hline & 2006 & 2007 & 2008 & 2009 & 2010 \\
\hline Top 5 companies (\%) & 50.1 & 54.6 & 41.3 & 43.7 & 50.3 \\
\hline Top 10 companies (\%) & 73.3 & 79.2 & 64.7 & 66.4 & 70.5 \\
\hline
\end{tabular}

Source: NAICOM.

Table 8. Nigeria: Market Share of the Top Ten Life Insurers, 2010 (In Million)

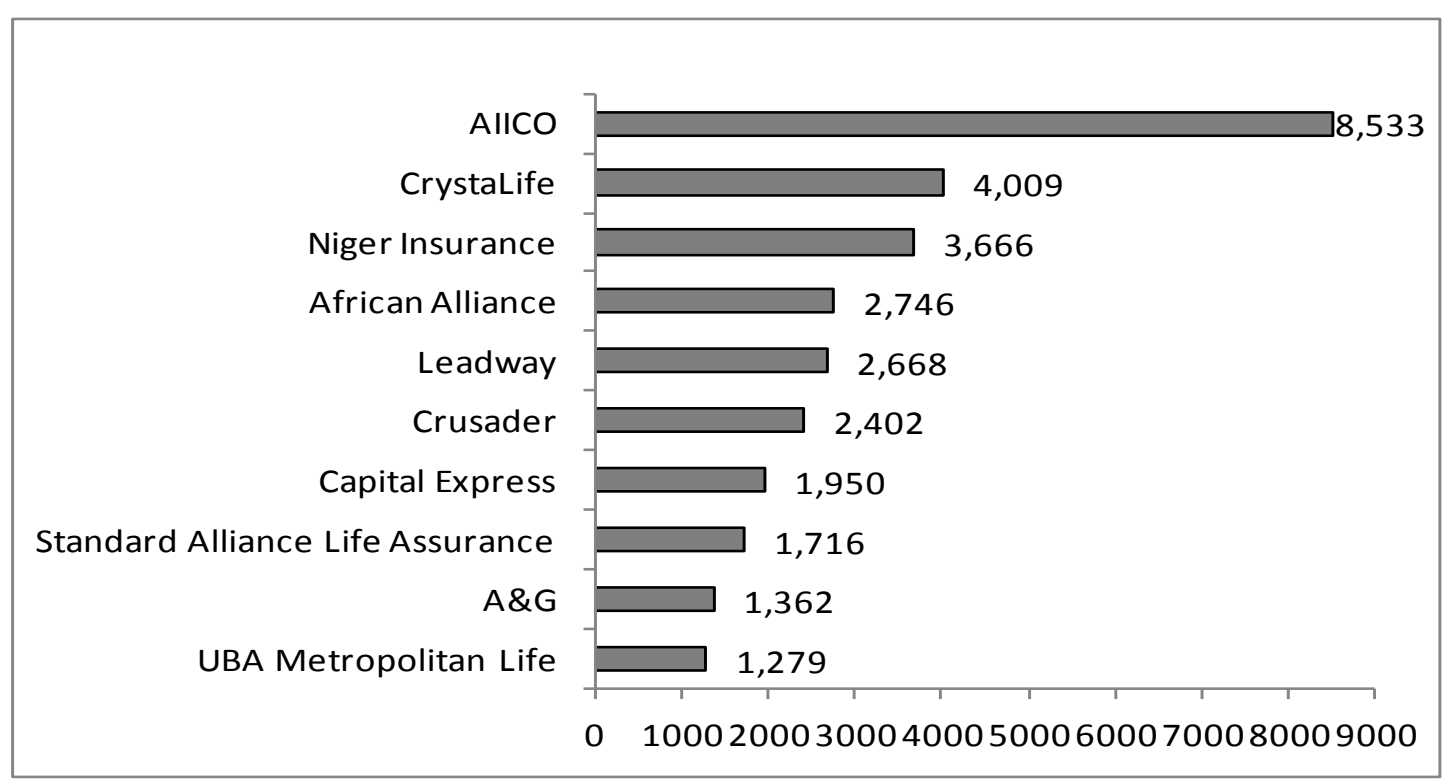

Source: NAICOM.

35. Reinsurance is influenced by market development considerations, at the cost of possible knowledge transfer. Direct insurers are required to retain at least 5 percent of the risks to discourage fronting of business (Tables 9 and 10). Reinsurance with foreign reinsurers requires NAICOM approval, subject to demonstrating that the insurer has exhausted local reinsurance capacity. Foreign reinsurers must have a minimum financial strength rating of A- (Standard and Poor's) or A (A.M. Best). There are two locally licensed reinsurers, along with a representative office of a regional reinsurance company and Africa $\mathrm{Re}$, neither of which are subject to NAICOM supervision. Insurers must satisfy the mandatory 5 percent cession to Africa Re before they seek coverage with other reinsurers. 70 percent of the oil and gas business must be retained in Nigeria and 100 percent for life business. As foreign reinsurers often provide product development and technical know-how to domestic direct insurers, the restriction of reinsurance with foreign reinsurers limits the knowledge transfer opportunities. 
Table 9. Nigeria: Level of Retention of the Non-life Insurers, 2010 (In Percent)

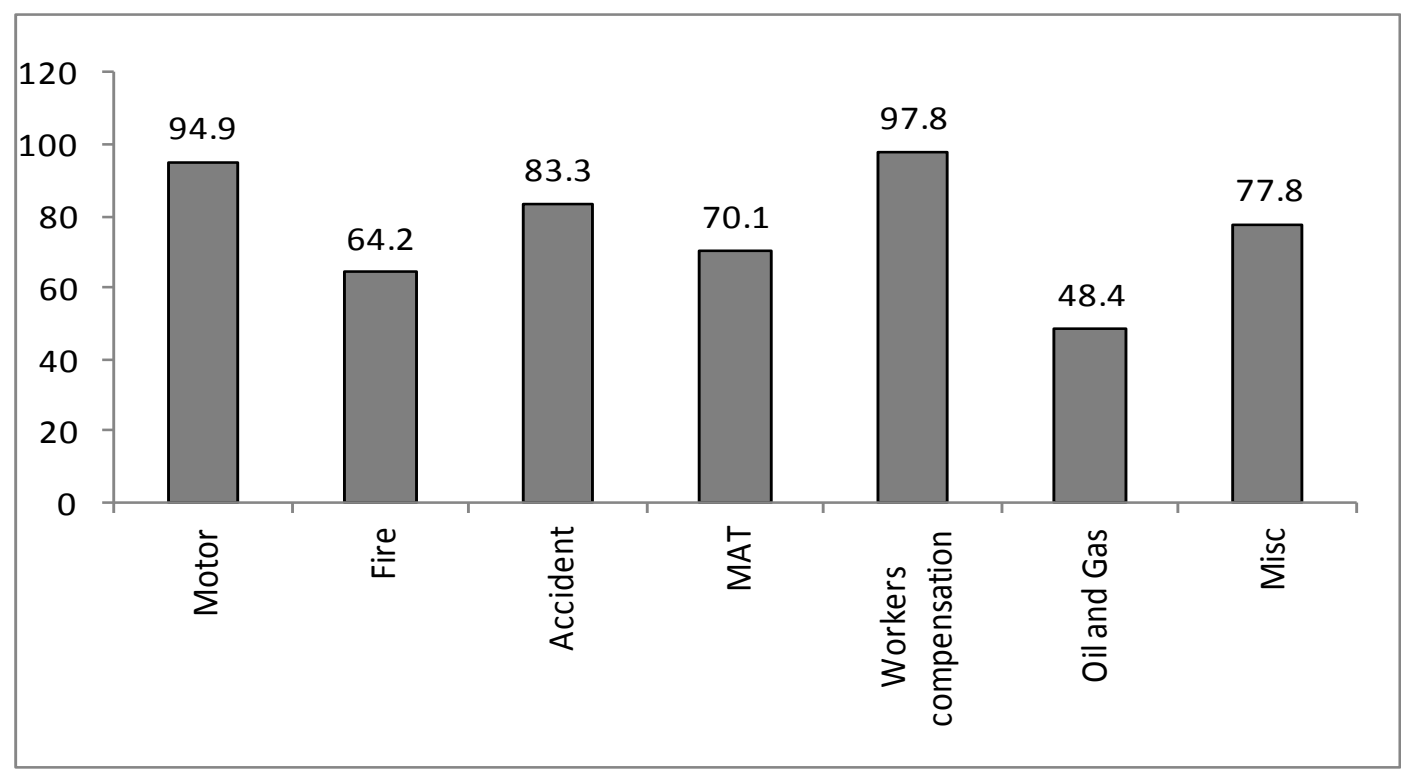

Source: Axco Global Statistics.

Table 10. Nigeria: Level of Retention of the Life Insurers, 2006-2010 (In Percent)

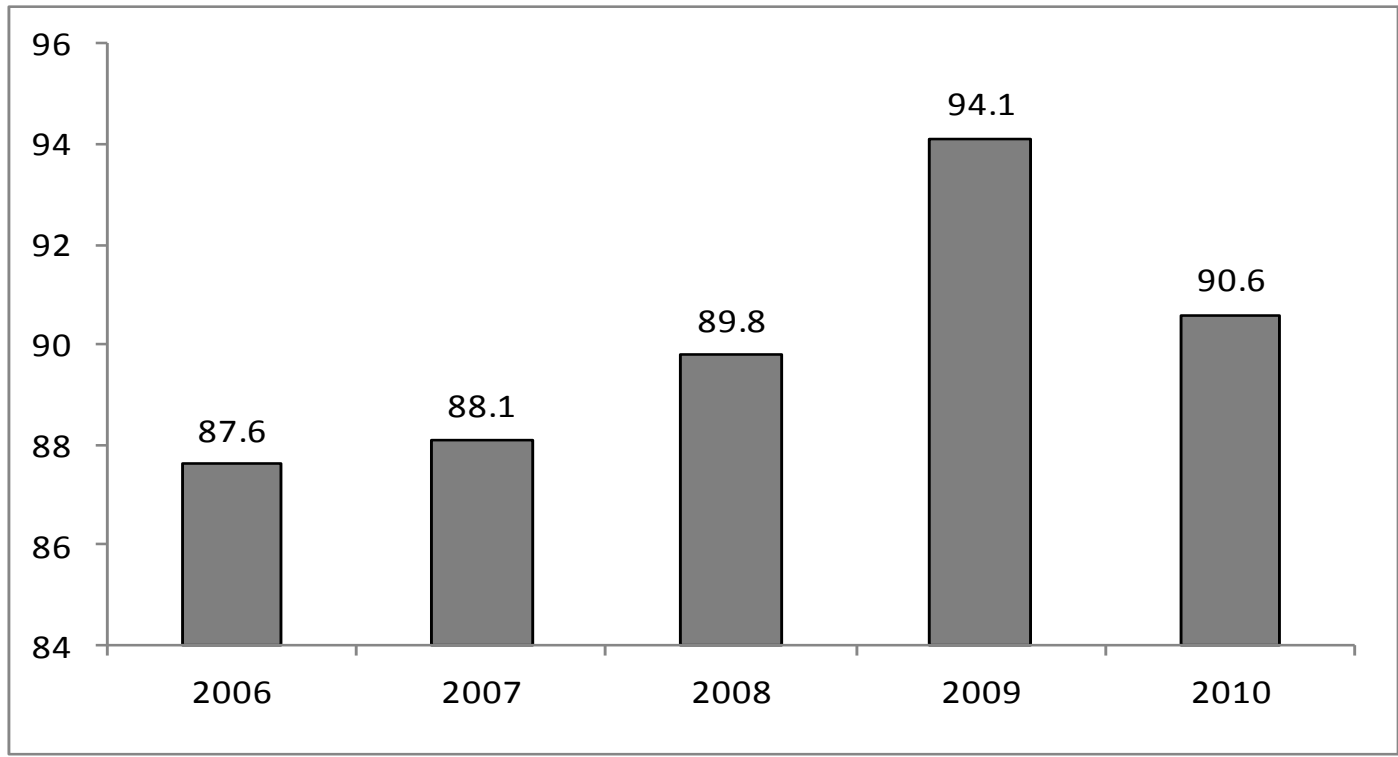

Source: Axco Global Statistics.

36. Both life and non-life companies have similar investment portfolios. The asset composition of insurers as indicated in Table 11 consists of short-term money market and bank deposits (43 percent for non-life and 34 percent for life), stock and private debentures accounting ( 25 percent for non-life and 22 percent for life) and the remaining investment are 
distributed among real estate, loans and government paper. The need for liquid assets reflects the short duration of the existing liabilities in both non-life and life, which is group life dominated with little long term individual life business. As the occupational pension system matures an increment in annuities is expected that will require long term investment instruments that currently are not readily available.

Table 11. Nigeria: Asset Mix of Insurers' Investments, 2011

\begin{tabular}{lrrrr}
\begin{tabular}{c} 
Type of Investment \\
\multicolumn{1}{c}{2011}
\end{tabular} & \multicolumn{2}{c}{$\begin{array}{c}\text { Non-Life } \\
\text { In million N }\end{array}$} & $\begin{array}{c}\text { Life } \\
\text { In percent }\end{array}$ \\
\hline Real Estate & $40,961.60$ & $21,624.45$ & 15.5 & 12.6 \\
Loans to Directors & 0.00 & 0.00 & 0.0 & 0.0 \\
Loans on Real Estate & 467.65 & 684.34 & 0.2 & 0.4 \\
Loans to Policy Holders & 0.00 & $3,025.12$ & 0.0 & 1.8 \\
Other Assets & $1,939.68$ & $1,037.38$ & 0.7 & 0.6 \\
Statutory Deposit & $14,177.65$ & $5,365.00$ & 5.4 & 3.1 \\
Government Bonds & $10,217.23$ & $12,000.22$ & 3.9 & 7.0 \\
Listed Ordinary Shares & $15,858.69$ & $17,470.72$ & 6.0 & 10.2 \\
Unlisted Ordinary Share & $26,700.93$ & $13,741.51$ & 10.1 & 8.0 \\
Listed Debenture & $1,807.65$ & 153.46 & 0.7 & 0.1 \\
Unlisted Debenture & $2,876.72$ & 3.67 & 1.1 & 0.0 \\
Short Term Investments & $94,522.12$ & $50,295.31$ & 35.8 & 29.3 \\
Shares in Related Companies & $19,854.16$ & $6,619.16$ & 7.5 & 3.9 \\
Loans to Related Companies & $3,942.25$ & $7,281.23$ & 1.5 & 4.2 \\
Other Investments & $12,159.08$ & $24,944.93$ & 4.6 & 14.5 \\
Cash In Hand & 61.61 & 2.34 & 0.0 & 0.0 \\
Bank Balance & $18,678.64$ & $7,530.42$ & 7.07 & 4.38 \\
\hline \multicolumn{1}{c}{ TOTAL } & $264,225.66$ & $171,779.26$ & 100.00 & 100.00 \\
\hline
\end{tabular}

Source: NAICOM.

\section{Preconditions for Effective Insurance Supervision}

37. Nigeria is a highly densely populated country with a petroleum-based economy. With 162 million people, Nigeria is the seventh most populous country in the world, and the largest in Africa. Nigeria's GDP of US\$169 billion (2009) is the $41^{\text {st }}$ highest in the world, and the second highest in Africa. A member of the Organization of Petroleum Exporting Countries (OPEC), Nigeria is the world's eighth largest oil producer and sixth largest oil exporter. It has the world's sixth largest deposits of natural gas. However, it's per capital GDP of US\$2,600 (PPP basis, 2011 estimate) is behind Ghana (US\$3,100) and Sudan (US\$3,000). ${ }^{5}$ Life expectancy of Nigerians is 51 years, and 55 percent of Nigerians live below the poverty line. ${ }^{6} 70$ percent of Nigeria's labor force is engaged in agriculture, which

\footnotetext{
${ }^{5}$ CIA World Fact Book.

${ }^{6}$ Data from the World Bank, 2004.
} 
accounts for 35 percent of GDP. Petroleum and petroleum products account for 95 percent of exports. Inflation was 13.8 percent in 2010 and 10.7 percent in 2011.

38. The legal and judiciary system is British in origin. Nigeria operates a federal political structure under the Constitution of the Federal Republic of Nigeria of 1999. The Federation consists of 36 States and a Federal Capital Territory. The constitution vests the legislative, executive and judicial powers in the National Assembly, the Executive and the courts established there under, respectively. The powers of the States are vested in similar bodies, except that the legislative body of the States is known as the House of Assembly. The development of the Nigerian legal system has been greatly influenced by its colonial past as a part of the British Commonwealth. The common law of England, the doctrines of equity as well as statutes of general application in force in England as at January 1, 1900 form an integral part of Nigerian laws in addition to certain English statutes that have been incorporated through local legislation. The principles of judicial precedent and hierarchy of courts is also a fundamental part of the legal system with the Supreme Court of Nigeria at the apex of the court system.

\section{The Financial Reporting Council (FRC) sets the accounting and auditing} standards for Nigeria. NAICOM is a member of the FRC and sits on the board. The FRC has adopted IFRS and NAICOM has required insurers to adopt IFRS in their financial reporting from 2012. All Big Four accounting firms have presence in Nigeria, as well as other international and local firms.

40. Under Nigerian Law, Auditors are appointed by a special resolution passed at an Annual General Meeting of a company. Persons who are entitled to be appointed as external auditors are accountants licensed by either the Institute of Chartered Accountants of Nigeria (ICAN) or members of the Association of National Accountants of Nigeria (ANAN). The Report on the Observance of Standards and Codes (ROSC) on Nigerian accounting and auditing practices issued in June 2011 found that there has been limited implementation of the 2004 Country Action Plan and limited improvement in financial reporting practices in Nigeria. The ROSC opined that the weaknesses in financial reporting, auditing and accounting contributed to Nigeria's banking sector crisis. NAICOM has mandated the adoption of IFRS from January 1, 2012. The effectiveness is yet to be seen.

41. There are few professional qualified actuaries working in Nigeria. The use of actuarial valuation is not mandatory for non-life insurers and it is only required every three years for life insurers. The low demand for external actuaries is covered by one actuarial firm. The leading institution in Nigeria offering an actuarial science degree program is the University of Lagos, Lagos, Nigeria. The institution has been providing a bachelor degree program for many decades. There is a local actuarial society called the Nigerian Actuarial Society which, like the University, has been in existence for more than two decades. The Actuarial society is affiliated to the International Actuarial Association (not a full member), however it has not been very active in promoting development of the profession and further 
education of the local actuaries and does not provide accreditation. Currently only five professionals working in Nigeria are fellows of foreign actuarial associations. The introduction of IFRS is creating demand for actuaries that currently the country cannot provide.

42. Some protection for claims against insolvent insurers is in place. The Insurance Act allows a portion of the levies collected from insurance institutions to be used for payment of any claims admitted by an insurance company where such claims remain unpaid by reason of insolvency or cancellation of the insurer's license. MAVICS provides compensation to individuals injured or killed by uninsured or unidentified drivers. Also, when an insurer is licensed, it must deposit 50 percent of the minimum capital with the CBN, which does add an element of policyholder protection in the event of non-payment of claims or insolvency.

\section{There is a need to develop investment instruments of medium to long durations.}

The insurers have access to the Nigerian Stock Exchange and there is also a money market infrastructure. While these are sufficient to meet current short term insurance liabilities there will be a need for longer-term investment instruments that currently do not exist, as the annuities and long term insurance markets develop. Types of instruments available include treasury bills, treasury certificates, certificate of deposits, commercial papers, shares, bonds of federal and state governments and companies, and unit trusts.

\section{E. Main Findings}

44. The legal status of guidelines issued by NAICOM should be clarified. NAICOM has the power under the law to make regulations and issue guidelines. The issuance of regulations is subject to the minister's approval while the issuance of guidelines is not. NAICOM has issued a number of significant prudential requirements in the form of guidelines, such as minimum capital, technical provisions; investment limits and risk management, although the AML/CFT requirements were issued in the form of regulations. NAICOM has taken the position that guidelines have the force of law, on par with regulations. The position has not yet been tested in courts. While the insurers have thus far complied with guidelines when prompted, it is nevertheless important to have legal certainty.

\section{Prudential and solvency requirements should be updated to better reflect the} risk profile of the operations. Technical provisions and solvency margins are factor-based without regard to the nature of risks. The basis of estimating liabilities is left to the insurers or actuaries in the case of life business. The regime is in urgent need of revamping to become commensurate with the intended move toward a risk-based supervision framework.

46. Poor accounting and auditing practices result in supervisors spending too much time in verifying the accuracy of financial data. Supervisors spend more time verifying data than analyzing data. This not only hinders effective supervision, but also timely disclosure of information to policyholders and the market in general. NAICOM should 
collaborate with the FRC to improve the reliability of the audited financial statements so that supervisors are able to focus more on both quantitative analysis and qualitative aspects of supervision. NAICOM should also take insurers and directors to task for submitting inaccurate information to promote proper corporate governance.

47. NAICOM has put in a lot of effort to improve the regulatory environment in the past five years. Following the recapitalization of insurers and reinsurers in 2007 to weed out unprofitable and insolvent companies, NAICOM has diligently upgraded its regulatory requirements, including a voluntary code on corporate governance, operational guidelines, risk management framework, KYC and AML/CFT requirements, and adoption of IFRS. These initiatives will significantly improve the regulatory environment for the industry when the industry has fully implemented these requirements. A critical success factor is to provide NAICOM officers with the necessary technical knowledge and supervisory skills suitable for the new regime.

48. Given the existing premium volume, the high capital requirements present a challenge to the attractiveness of the sector. Except for the largest insurers, the return on equity is low as a result of low premium volume and high capital base. While the high capital is sensible to ensure professionalism in the industry, there is a need to study the appropriateness of the capital requirement to balance risk, return and development. The minimum paid-up capital should be evaluated when introducing risk-based capital so that capital adequacy will reflect the risks that the insurer takes on.

49. Several insurers are in urgent need to evaluate their business viability. Some insurers need capital injection to comply with solvency requirements. Few insurers have made profits for 2011 according the unofficial numbers available to NAICOM as of September 2012. The drop in stock prices of over 60 percent since 2007 has affected investments in the insurance sector resulting in several publicly traded insurers losing all share premia and are currently trading at nominal value or the minimal share value required for listing, as indicated in Table 12. 
Table 12. Nigeria: Market Capitalization of Listed Insurers, July 2012

\begin{tabular}{|c|c|c|c|c|}
\hline & Insurance Carriers, Brokers and Services & $\begin{array}{c}\text { Price in } \\
\text { Naira } \\
\end{array}$ & $\begin{array}{c}\text { Quantity Issued/ } \\
\text { Market Value }\end{array}$ & Market Capitalization \\
\hline 1 & Guaranty Trust Assurance Plc & 1.60 & $10,000,000,000$ & $16,000,000,000.00$ \\
\hline 2 & Investment and Allied Assurance & 0.50 & $28,000,000,000$ & $14,000,000,000.00$ \\
\hline 3 & African Alliance Company Plc & 0.50 & $20,585,000,000$ & $10,292,500,000.00$ \\
\hline 4 & Universal Insurance Company Plc & 0.50 & $16,000,000,000$ & $8,000,000,000.00$ \\
\hline 5 & Custodian and Allied Insurance Plc & 1.50 & $5,100,846,808$ & $7,651,270,212.00$ \\
\hline 6 & Continental Reinsurance Plc & 0.67 & $10,372,744,312$ & $6,949,738,689.04$ \\
\hline 7 & Unity Kapital Assurance Plc & 0.50 & $13,000,000,000$ & $6,500,000,000.00$ \\
\hline 8 & Equity Assurance Plc. & 0.50 & $8,847,298,420$ & $4,423,649,210.00$ \\
\hline 9 & Cornerstone Insurance Company & 0.50 & $8,820,010,000$ & $4,410,005,000.00$ \\
\hline 10 & Standard Alliance Insurance Plc & 0.50 & $8,493,173,450$ & $4,246,586,725.00$ \\
\hline 11 & Mutual Benefits Assurance Plc & 0.50 & $7,998,705,336$ & $3,999,352,668.00$ \\
\hline 12 & Lasaco Assurance Plc & 0.50 & $7,323,313,227$ & $3,661,656,613.50$ \\
\hline 13 & Intercontinental Wapic Insurance Plc & 0.72 & $5,061,804,000$ & $3,644,498,880.00$ \\
\hline 14 & AIICO Insurance Plc & 0.50 & $6,930,204,480$ & $3,465,102,240.00$ \\
\hline 15 & Sovereign Trust Insurance Plc & 0.50 & $6,871,757,394$ & $3,435,878,697.00$ \\
\hline 16 & Regency Alliance Insurance & 0.50 & $6,668,750,000$ & $3,334,375,000.00$ \\
\hline 17 & Oasis Insurance Plc & 0.50 & $6,503,506,792$ & $3,251,753,396.00$ \\
\hline 18 & International Energy Insurance Company & 0.50 & $6,420,427,449$ & $3,210,213,724.50$ \\
\hline 19 & Staco Insurance Plc & 0.50 & $6,141,087,609$ & $3,070,543,804.50$ \\
\hline 20 & Niger Insurance Co. Plc & 0.53 & $5,736,598,471$ & $3,040,397,189.63$ \\
\hline 21 & Consolidated Hallmark Insurance Plc & 0.50 & $6,000,000,000$ & $3,000,000,000.00$ \\
\hline 22 & Guinea Insurance Plc & 0.50 & $5,400,000,000$ & $2,700,000,000.00$ \\
\hline 23 & N.E.M Insurance Co (NIG) Plc & 0.50 & $5,280,502,913$ & $2,640,251,456.50$ \\
\hline 24 & Linkage Assurance Plc & 0.50 & $5,102,792,152$ & $2,551,396,076.00$ \\
\hline 25 & Goldlink Insurance Plc & 0.56 & $4,549,947,000$ & $2,547,970,320.00$ \\
\hline 26 & Great Nigerian Insurance Plc & 0.50 & $3,827,485,380$ & $1,913,742,690.00$ \\
\hline 27 & Law Union and Rock Insurance Plc & 0.50 & $3,437,330,500$ & $1,718,665,250.00$ \\
\hline 28 & Unic Insurance Plc & 0.50 & $2,581,702,105$ & $1,290,851,052.50$ \\
\hline 29 & Prestige Assurance Co. Plc & 0.51 & $2,508,315,436$ & $1,279,240,872.36$ \\
\hline 30 & Confidence Insurance Plc & 0.61 & $211,626,000$ & $129,091,860.00$ \\
\hline \multicolumn{4}{|c|}{ TOTAL } & $136,358,731,626.53$ \\
\hline
\end{tabular}

Source: Nigerian Stock Exchange.

50. Government policy is actively addressing the need for growth of the sector; however enforcement of compulsory insurance is suboptimal. There are six classes of compulsory insurance but enforcement is weak. More effective enforcement will provide a substantial stable premium income for the industry. NAICOM recognizes this and has been working with other relevant authorities to strengthen enforcement. Under this initiative, a motor insurance database will be launched in the coming months, aiming to stamp out rampant fake motor insurance certificates, by providing a quick and easy way for the enforcement agency and customers to verify the authenticity of insurance certificates.

\section{Consumer protection needs to be treated with high priority. As the compulsory} insurance is enforced, the cost of intermediation of compulsory insurance and the purchase of retirement annuities need to be addressed to improve efficiency of the market. NAICOM should improve the disclosure standards, requiring intermediaries to disclose their capacity to act (whether as agent or broker), their financial interest in the policy, and any conflict of 
interest that might affect their recommendation of products. For annuities, electronic bidding models like the one existing in Chile would benefit the annuitants by enhanced cost transparency and reducing intermediation costs.

\section{Table 13. Nigeria: Summary of Observance of the Insurance Core Principles}

\begin{tabular}{|c|c|c|c|}
\hline & Insurance Core Principle & Level & Overall Comments \\
\hline 1 & $\begin{array}{l}\text { Objectives, Powers and Responsibilities of the } \\
\text { Supervisor }\end{array}$ & $\mathrm{O}$ & \\
\hline 2 & Supervisor & LO & \\
\hline 3 & Information Exchange and Confidentiality Requirements & LO & \\
\hline 4 & Licensing & LO & \\
\hline 5 & Suitability of Persons & $\mathrm{PO}$ & \\
\hline 6 & Changes in Control and Portfolio Transfers & $\mathrm{PO}$ & \\
\hline 7 & Corporate Governance & LO & \\
\hline 8 & Risk Management and Internal Controls & LO & \\
\hline 9 & Supervisory Review and Reporting & $\mathrm{PO}$ & \\
\hline 10 & Preventive and Corrective Measures & LO & \\
\hline 11 & Enforcement & LO & \\
\hline 12 & Winding-up and Exit from the Market & $\mathrm{O}$ & \\
\hline 13 & Reinsurance and Other Forms of Risk Transfer & $\mathrm{PO}$ & \\
\hline 14 & Valuation & $\mathrm{PO}$ & \\
\hline 15 & Investment & LO & \\
\hline 16 & Enterprise Risk Management for Solvency Purposes & $\mathrm{PO}$ & \\
\hline 17 & Capital Adequacy & $\mathrm{PO}$ & \\
\hline 18 & Intermediaries & $\mathrm{PO}$ & \\
\hline 19 & Conduct of Business & $\mathrm{PO}$ & \\
\hline 20 & Public Disclosure & $\mathrm{PO}$ & \\
\hline 21 & Countering Fraud in Insurance & $\mathrm{PO}$ & \\
\hline 22 & $\begin{array}{l}\text { Anti-Money Laundering and Combating the Financing of } \\
\text { Terrorism }\end{array}$ & LO & \\
\hline 23 & Group-wide Supervision & NO & \\
\hline 24 & $\begin{array}{l}\text { Macroprudential Surveillance and Insurance } \\
\text { Supervision }\end{array}$ & $\mathrm{PO}$ & \\
\hline 25 & Supervisory Cooperation and Coordination & $\mathrm{PO}$ & \\
\hline 26 & $\begin{array}{l}\text { Cross-border Cooperation and Coordination on Crisis } \\
\text { Management }\end{array}$ & NO & \\
\hline
\end{tabular}

\section{Summary of Observance Level}

\begin{tabular}{|l|c|}
\hline Observed (O) & 2 \\
\hline Largely observed (LO) & 9 \\
\hline Partly observed (PO) & 13 \\
\hline Not Observed (NO) & 2 \\
\hline Total & $\mathbf{2 6}$ \\
\hline
\end{tabular}




\section{F. Recommendations and the Authorities' Responses}

\section{Recommendation to improve observance of ICPs}

\section{Table 14. Nigeria: Recommendations to Improve Observance of ICPs}

\begin{tabular}{|c|c|}
\hline Insurance Core Principle & Recommendations \\
\hline $\begin{array}{l}\text { 1. Objectives, Powers and } \\
\text { Responsibilities of the } \\
\text { Supervisor }\end{array}$ & $\begin{array}{l}\text { It is advised that NAICOM expand the objective to include the creation of a } \\
\text { fair, safe and stable insurance sector for the benefit and protection of } \\
\text { policyholders. } \\
\text { NAICOM is advised to seek legal clarity on the legal standing of guidelines. }\end{array}$ \\
\hline 2. Supervisor & $\begin{array}{l}\text { To enhance operational independence and facilitate timely supervisory } \\
\text { action, NAICOM should be the final authority in exercising its supervisory } \\
\text { powers without having to seek the minister's approval for operational } \\
\text { matters, such as appointment and dismissal of control positions. } \\
\text { NAICOM should strive to strengthen its human capital, so that it will not } \\
\text { rely on third-party consultants to carry out routine on-site inspections. }\end{array}$ \\
\hline $\begin{array}{l}\text { 3. Information Exchange } \\
\text { and Confidentiality } \\
\text { Requirements }\end{array}$ & $\begin{array}{l}\text { For the avoidance of doubt, the NAICOM Act } 1997 \text { should be amended to } \\
\text { give NAICOM explicit power to exchange supervisory information subject } \\
\text { to appropriate confidentiality, purpose and use safeguards. } \\
\text { NAICOM is encouraged to accede to the IAIS MMOU. } \\
\text { NAICOM should establish procedures in handling request for information in } \\
\text { the absence of an MOU to ensure consistent assessment of such } \\
\text { requests. }\end{array}$ \\
\hline 4. $\quad$ Licensing & $\begin{array}{l}\text { NAICOM is advised to including considering the applicant's corporate } \\
\text { governance framework and its group structure to ensure it is not too } \\
\text { complex to be effectively supervision. } \\
\text { To ensure that insurers have the necessary financial resources and } \\
\text { competence in writing business, NAICOM is advised to consider granting } \\
\text { license by lines of business. }\end{array}$ \\
\hline 5. Suitability of Persons & $\begin{array}{l}\text { NAICOM should ensure that significant owners and key persons in control } \\
\text { positions are suitable. } \\
\text { NAICOM should consider explicitly approving the appointment of directors, } \\
\text { on par with the appointment of CEOs. } \\
\text { In assessing the suitability of key persons, NAICOM is advised to include } \\
\text { competence, financial and other indicators. } \\
\text { To ensure suitability on an ongoing basis, NAICOM should formalize the } \\
\text { existing practice of subjecting newly appointed directors to suitability test } \\
\text { by requiring insurers to report any changes in board membership to } \\
\text { NAICOM. This should be extended to include key person in control } \\
\text { positions as well. }\end{array}$ \\
\hline $\begin{array}{l}\text { 6. Changes in Control and } \\
\text { Portfolio Transfers }\end{array}$ & $\begin{array}{l}\text { It is not clear that the } 25 \text { percent change in control requirement in the } \\
\text { Operational Guidelines is enforceable, as it is not derived from any } \\
\text { provisions in the primary legislation. NAICOM should amend the primary } \\
\text { legislation to solidify its supervisory intention. At the same time, NAICOM } \\
\text { should clarify (a) whether the threshold shareholding is based on issued } \\
\text { shares of voting shares, and (b) it applies to both acquisition and disposal }\end{array}$ \\
\hline
\end{tabular}




\begin{tabular}{|c|c|}
\hline \multirow[t]{2}{*}{ Insurance Core Principle } & Recommendations \\
\hline & $\begin{array}{l}\text { of shares. } \\
\text { NAICOM may wish to consider progressive thresholds, rather than a } \\
\text { single-point threshold. For example, an insurer should notify NAICOM } \\
\text { when an individual gains control of } 5 \text { percent, } 10 \text { percent, and } 20 \text { percent } \\
\text { of its voting shares. } \\
\text { NAICOM should be able to identify the intended beneficial owner in a } \\
\text { proposed change in control application, and evaluate the application as if it } \\
\text { were an application for a new license, taking into account how } \\
\text { policyholders' interest might be affected. }\end{array}$ \\
\hline 7. Corporate Governance & $\begin{array}{l}\text { Since the CGCG is relatively new, there are several fine-tuning that } \\
\text { NAICOM may wish to consider to improve the code: } \\
\text { - Various regulators have issued corporate governance code: the } \\
\text { Corporate Affairs Commission, the Stock Exchange, NAICOM and } \\
\text { CBN. These regulators should discuss and consider a unified code to } \\
\text { avoid market confusion. } \\
\text { - Independent directors are expected to have a "critical" role in } \\
\text { evaluation of the board's performance. At the same time, CGCG } \\
\text { requires an outside consultant to perform such evaluation. Clarification } \\
\text { should be given regarding the role of independent director in } \\
\text { evaluation of board performance, relative to the external consultant. } \\
\text { - Section } 5.04 \text { (xi) of CGCG states: "Any individual taking major action in } \\
\text { the running of the company must either be a member of the Board, the } \\
\text { management or paid consultant." The role of paid consultant in the } \\
\text { running of the company is unclear. } \\
\text { Responsibility of the board is to "establish" strategy, not merely } \\
\text { review. } \\
\text { CGCG states that the appointment of external audit is subject to } \\
\text { NAICOM approval. NAICOM has not explicitly required insurers to do } \\
\text { so. } \\
\text { CGCG advocates disclosure of conflict of interest disclosure by all } \\
\text { employees to the board or shareholders. To avoid board being } \\
\text { inundated with declarations, such disclosure should be made to } \\
\text { management, except in the case of senior management and key } \\
\text { people in control positions. } \\
\text { Other than the audit committee, the roles of other board committees } \\
\text { are not specified. CGCG could be expanded to require each board } \\
\text { committee to have terms of reference. } \\
\text { Internal audit should have a direct reporting line to the audit committee of } \\
\text { account the mix of knowledge, skills and expertise of directors. There } \\
\text { should be more than one independent director. }\end{array}$ \\
\hline $\begin{array}{l}\text { 8. Risk Management and } \\
\text { Internal Controls }\end{array}$ & $\begin{array}{l}\text { There are two additional areas that NAICOM could include in the RM } \\
\text { Guidelines: } \\
\text { - } \quad \text { Explicit approve the appointment of heads of key control positions. }\end{array}$ \\
\hline
\end{tabular}




\begin{tabular}{|c|c|}
\hline Insurance Core Principle & Recommendations \\
\hline & $\begin{array}{l}\text { Clarify the insurer's responsibility in outsourcing material functions, } \\
\text { including the selecting the service provider, approving procedures, } \\
\text { service contract, review of contract, and insurer's accountability on } \\
\text { outsourced functions. } \\
\text { NAICOM should also expand on the requirement for insurers to have } \\
\text { disaster recovery/business continuity plan, by (a) specifying the required } \\
\text { recovery time based on functional criticality; and (b) requiring periodic } \\
\text { testing of the business continuity plan }\end{array}$ \\
\hline $\begin{array}{l}\text { 9. } \begin{array}{l}\text { Supervisory Review and } \\
\text { Reporting }\end{array}\end{array}$ & $\begin{array}{l}\text { NAICOM is advised to collaborate with the FRC to improve the quality of } \\
\text { audits, and to take stern action against any insurer and its directors for not } \\
\text { having appropriate systems in place to ensure the reliability of financial } \\
\text { information, so that resources can be channel to more strategic } \\
\text { supervisory work. } \\
\text { Together with FRC, NAICOM should work with the industry to identify the } \\
\text { obstacles to the effective implementation of IFRS. } \\
\text { Onsite inspection is an integral part of supervision, enabling supervisors to } \\
\text { have firsthand knowledge of the operations, NAICOM should develop its } \\
\text { own supervisory capacity and use consultants only in specialized fields } \\
\text { such as IT risk assessment or forensic investigations. } \\
\text { Both onsite and offsite supervision is currently compliance driven. With the } \\
\text { release of the RM Guidelines and the impending move to risk-based } \\
\text { supervision, NAICOM need to develop an comprehensive staff training } \\
\text { program on understanding risks, evaluating effectiveness of risk } \\
\text { management and internal controls, and assessing the financial resilience } \\
\text { of an insurer. }\end{array}$ \\
\hline $\begin{array}{l}\text { 10. Preventive and } \\
\text { Corrective Measures }\end{array}$ & $\begin{array}{l}\text { Certain supervisory actions are subject to minister's approval. To ensure } \\
\text { timely intervention, NAICOM should have the autonomy to take preventive } \\
\text { and corrective action without applying to minister for approval. } \\
\text { NA provides that NAICOM may, with minister's approval, apply to } \\
\text { President to revoke an insurer's license. IA, on the other hand, provides } \\
\text { that NAICOM may cancel the license under certain circumstances. As } \\
\text { there is no practical difference between revocation and cancellation, } \\
\text { NAICOM's power to revoke/cancel a license should be consistent in the } \\
\text { two legislations. }\end{array}$ \\
\hline 11. Enforcement & $\begin{array}{l}\text { Similar to ICP 10, NAICOM should have the autonomy to take enforcement } \\
\text { action without applying to minister for approval in order to ensure timely } \\
\text { action. }\end{array}$ \\
\hline $\begin{array}{l}\text { 12. Winding-up and Exit } \\
\text { from the Market }\end{array}$ & $\begin{array}{l}\text { While it may be appropriate for policyholders to bring legal action against } \\
\text { an insurer, the ability to petition the Court to liquidate an insurer may afford } \\
\text { too much power to any } 50 \text { individuals. It may in fact be detrimental to the } \\
\text { public and other policyholders. The power to wind-up an insurer should be } \\
\text { the sole responsibility of the insurance supervisor. It is recommended to } \\
\text { remove this provision from the legislation. }\end{array}$ \\
\hline $\begin{array}{l}\text { 13. Reinsurance and Other } \\
\text { Forms of Risk Transfer }\end{array}$ & $\begin{array}{l}\text { Mandatory cessions and the exclusive use of local reinsurance should be } \\
\text { waived if contravening the board's reinsurance policy. } \\
\text { It is advised that NAICOM should expand the scope of the reinsurance } \\
\text { component of onsite inspection programs to take into account the } \\
\text { reinsurance guidelines, and include consideration of liquidity and }\end{array}$ \\
\hline
\end{tabular}




\begin{tabular}{|c|c|}
\hline Insurance Core Principle & Recommendations \\
\hline & $\begin{array}{l}\text { reinsurers' payment pattern. } \\
\text { Reinsurance programs should only be allowed that pass a risk transfer test } \\
\text { and to enhance transparency side letter should be forbidden by requiring } \\
\text { the entire contract clause in each treaty. }\end{array}$ \\
\hline 14. Valuation & 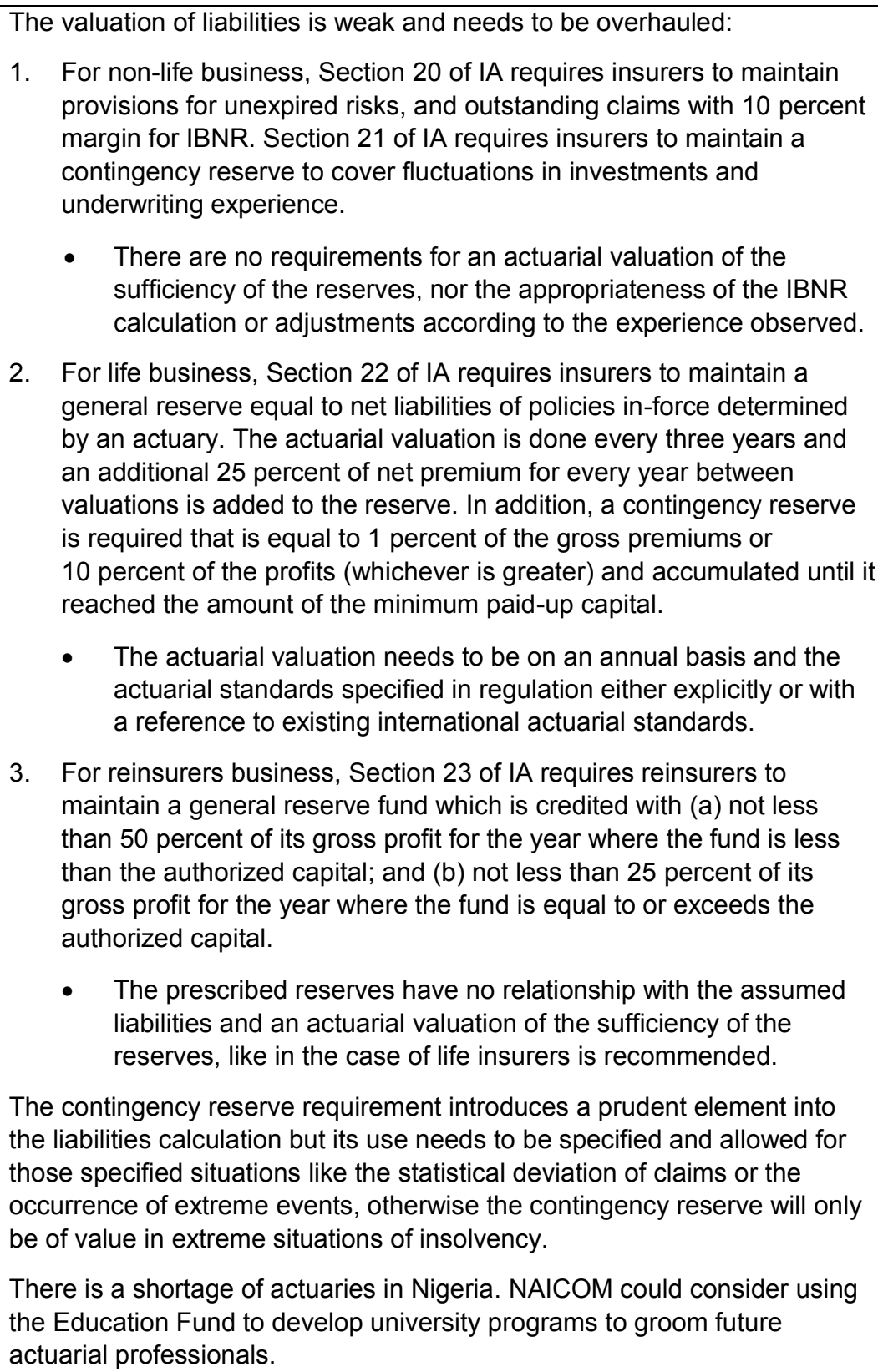 \\
\hline 15. Investment & $\begin{array}{l}\text { NAICOM should consider introducing a well defined overarching prudent } \\
\text { man type of concept to guide the investments of insurers. This will cover all } \\
\text { risk, without leaving a regulatory gap and without being too prescriptive. In } \\
\text { the initial stage of introduction, close monitoring and a detailed guidance } \\
\text { on what is expected from the investments' policy is recommended. } \\
\text { There should be explicit requirement on the use of more complex and less } \\
\text { transparent classes of investments in markets or instruments that are }\end{array}$ \\
\hline
\end{tabular}




\begin{tabular}{|c|c|}
\hline Insurance Core Principle & Recommendations \\
\hline & $\begin{array}{l}\text { subject to less governance or regulation. Given the current level of } \\
\text { investment expertise in the industry prohibition of the use of derivatives is } \\
\text { also recommended. } \\
\text { It is recommended to require that policyholder's assets of investment } \\
\text { product be segregated in independent trusts. }\end{array}$ \\
\hline $\begin{array}{l}\text { 16. Enterprise Risk } \\
\text { Management for } \\
\text { Solvency Purposes }\end{array}$ & $\begin{array}{l}\text { NAICOM should include the following in the RM Guidelines: stress testing } \\
\text { as a tool to assess risk, asset-liability management, and insurer's own } \\
\text { assessment of solvency. }\end{array}$ \\
\hline 17. Capital Adequacy & $\begin{array}{l}\text { NAICOM is aware of the drawbacks of current simplistic solvency regime. } \\
\text { As part of its strategic plan to move toward risk-based supervision, } \\
\text { NAICOM intends to move toward a regime of risk-based capital. It is } \\
\text { recommended to treat this initiative with highest priority. NAICOM should } \\
\text { review the appropriateness of the existing minimum paid-up capital under } \\
\text { the pending risk-based capital regime. }\end{array}$ \\
\hline 18. Intermediaries & $\begin{array}{l}\text { NAICOM should require insurance intermediaries to disclose to customers } \\
\text { their capacity as agents or brokers, how they are paid, range of products } \\
\text { and potential conflict of interest when the intermediary is part of an } \\
\text { insurance group. } \\
\text { NAICOM needs to increase its efforts to reduce the amount of outstanding } \\
\text { premiums remain with the brokers. }\end{array}$ \\
\hline 19. Conduct of Business & $\begin{array}{l}\text { NAICOM is advised to issue market conduct regulations incorporating the } \\
\text { principles of treating customers fairly in each stage of insurance business: } \\
\text { product design, marketing, fact-find, giving advice, underwriting, policy } \\
\text { service, and claim. } \\
\text { NAICOM should require segregation of insurance funds for participating } \\
\text { and non-participating business to facilitate the proper determination of } \\
\text { experience sharing. There should be requirements on the profit sharing } \\
\text { between participating policyholders and shareholders. Actuary should } \\
\text { certify that allocation of bonus to participating policies meets regulatory } \\
\text { requirements and policyholders' reasonable expectation. } \\
\text { NAICOM should also address the advisory and disclosure standard for } \\
\text { participating products, with emphasis on distinguishing guaranteed verse } \\
\text { non-guaranteed elements of the policy. } \\
\text { Customer complaint is an indicator of weakness in operation or internal } \\
\text { controls. NAICOM should require insurers to have in place complaints } \\
\text { handling procedures and examine how insurers handle complaints during } \\
\text { on-site inspections. }\end{array}$ \\
\hline 20. Public Disclosure & $\begin{array}{l}\text { There are no requirements on the content of the annual report. } \\
\text { Consequently, policyholders and market participants in most cases do not } \\
\text { have access to relevant information, such as the insurer's strategies, risks, } \\
\text { financial condition, and performance. The situation is likely to improve with } \\
\text { the adoption of IFRS from 2012. NAICOM should monitor the quality of } \\
\text { disclosures and issue guidelines and/or guidance notes in the future if } \\
\text { appropriate. } \\
\text { NAICOM should shorten the timeline to ensure more timely dissemination } \\
\text { of information. The possibility of a reduction to three months from the } \\
\text { current six months for the submission of the annual statements should be } \\
\text { considered, in conjunction with efforts to strengthen quality of audits. }\end{array}$ \\
\hline
\end{tabular}




\begin{tabular}{|c|c|}
\hline Insurance Core Principle & Recommendations \\
\hline $\begin{array}{l}\text { 21. Countering Fraud in } \\
\text { Insurance }\end{array}$ & $\begin{array}{l}\text { NAICOM should explicitly require insurers to have in place procedures to } \\
\text { deter, detect, prevent and remedy frauds. } \\
\text { NAICOM is advised to make use of the fraud reports to understand the } \\
\text { types of fraud risks, to analyze overall market vulnerability, to assess the } \\
\text { effectiveness of each insurer's fraud preventive measures, and to improve } \\
\text { the overall effectiveness through shared experience. }\end{array}$ \\
\hline $\begin{array}{l}\text { 22. Anti-Money Laundering } \\
\text { and Combating the } \\
\text { Financing of Terrorism }\end{array}$ & $\begin{array}{l}\text { NAICOM is recommended to critically analyse the strategy and business } \\
\text { plans of insurers that are not producing significant business volume in } \\
\text { relation to the capital requirements. }\end{array}$ \\
\hline 23. Group-wide Supervision & $\begin{array}{l}\text { NAICOM is advised to amend primary legislation to provide explicit power } \\
\text { to conduct group-wide supervision. } \\
\text { NAICOM should require insurance group structure to be sufficiently } \\
\text { transparent so as not to hinder group-wide supervision. } \\
\text { The group-wide supervision framework should extend the following legal } \\
\text { entity requirements to the group level: solvency assessment, governance, } \\
\text { risk management, and market conduct. }\end{array}$ \\
\hline $\begin{array}{l}\text { 24. Macroprudential } \\
\text { Surveillance and } \\
\text { Insurance Supervision }\end{array}$ & $\begin{array}{l}\text { NAICOM should consider developing a macroprudential surveillance } \\
\text { system, including industry-wide stress tests to identify trends, potential } \\
\text { risks and plausible future unfavorable scenarios, so that it may take early } \\
\text { action to reduce the likelihood of systemic risk. NAICOM could leverage on } \\
\text { the existing FSRCC forum for this purpose. } \\
\text { In performing its macroprudential surveillance, NAICOM should use entity } \\
\text { as well as group-wide data to analyze and monitor potential impact on the } \\
\text { financial stability of particular insurers and insurance market as a whole, } \\
\text { and to assess the financial market risks impinge on prudential safeguards. } \\
\text { NAICOM should also establish process to assess the potential systemic } \\
\text { importance of insurers, and to develop an appropriate supervisory } \\
\text { response. }\end{array}$ \\
\hline $\begin{array}{l}\text { 25. Supervisory } \\
\text { Cooperation and } \\
\text { Coordination }\end{array}$ & $\begin{array}{l}\text { In the immediate term, NAICOM should build on its MOU with Ghana to } \\
\text { include the process for the two supervisors to discuss and determine the } \\
\text { need for group-wide supervision and to agree on the designated group- } \\
\text { wide supervisor. }\end{array}$ \\
\hline $\begin{array}{l}\text { 26. Cross-border } \\
\text { Cooperation and } \\
\text { Coordination on Crisis } \\
\text { Management }\end{array}$ & $\begin{array}{l}\text { Cross-border crisis management is not a high priority for Nigeria at this } \\
\text { stage. Nonetheless, NAICOM should work toward establishing } \\
\text { methodology in identifying SIFls and protocol on cross-border coordination } \\
\text { on crisis management. }\end{array}$ \\
\hline
\end{tabular}

\section{Authorities' Response to the Assessment}

NAICOM appreciates the work performed by the IMF to prepare this FSAP and are grateful for being given the opportunity to comment on the findings.

NAICOM essentially agrees with the recommendations made, some of which actually backs up existing efforts NAICOM has undertaken so far to strengthen insurance supervision.

The IMF assessment concludes that "NAICOM has made a lot of effort over the past five 
years to improve the regulatory environment." NAICOM welcomes the recognition of the efforts made in particular efforts in our vigilance in ensuring the accuracy of financial information and enforcing compliance according to international best practices.

NAICOM have an ambitious agenda to continue to introduce new regulation and tools to keep improving the supervisory action, making it more efficient and adapted to the current economic environment.

A new insurance bill which has been under preparation for some time and which will soon be proceeding through the legislative process, would substantially address most of the issues raised in the assessment.

The IMF assessment team noted that ICP 18, 19, 20, and 21 are only "Partly observed" because of issues relating to intermediaries disclosure of capacity, outstanding premiums, customer fair treatment and timely dissemination of information for public disclosure. These issues are being addressed; there is a draft guideline on market code of conduct code and another draft guideline on claims and complaints procedure. IFRS transition has also commenced since the beginning of this year and will address many public disclosure areas.

The Road Map and ongoing works to transit to Risk Based Supervision and Risk Based Capital will also tackle some of the other concerns raised in the assessment.

Some improvements have already been achieved in our HR strategy, through the hiring of staff and professionals from the private sector with industry experience. These efforts will continue; and they will be further supported by on-going plans to develop a robust IT infrastructure. This development will enable full data storage capabilities and enhanced automation of financial data and financial analysis.

The recommendations of the IMF are therefore well received and NAICOM will continue to work towards their progressive implementation in the continuous efforts for strengthening insurance supervision. 


\section{Detailed ASSESSMent}

\section{Table 15. Nigeria: Detailed Assessment of Observance of the Insurance Core Principles}

\begin{tabular}{|c|c|}
\hline ICP 1 & $\begin{array}{l}\text { Objectives, Powers and Responsibilities of the Supervisor } \\
\text { The authority (or authorities) responsible for insurance supervision and the objectives of } \\
\text { insurance supervision are clearly defined. }\end{array}$ \\
\hline Description & 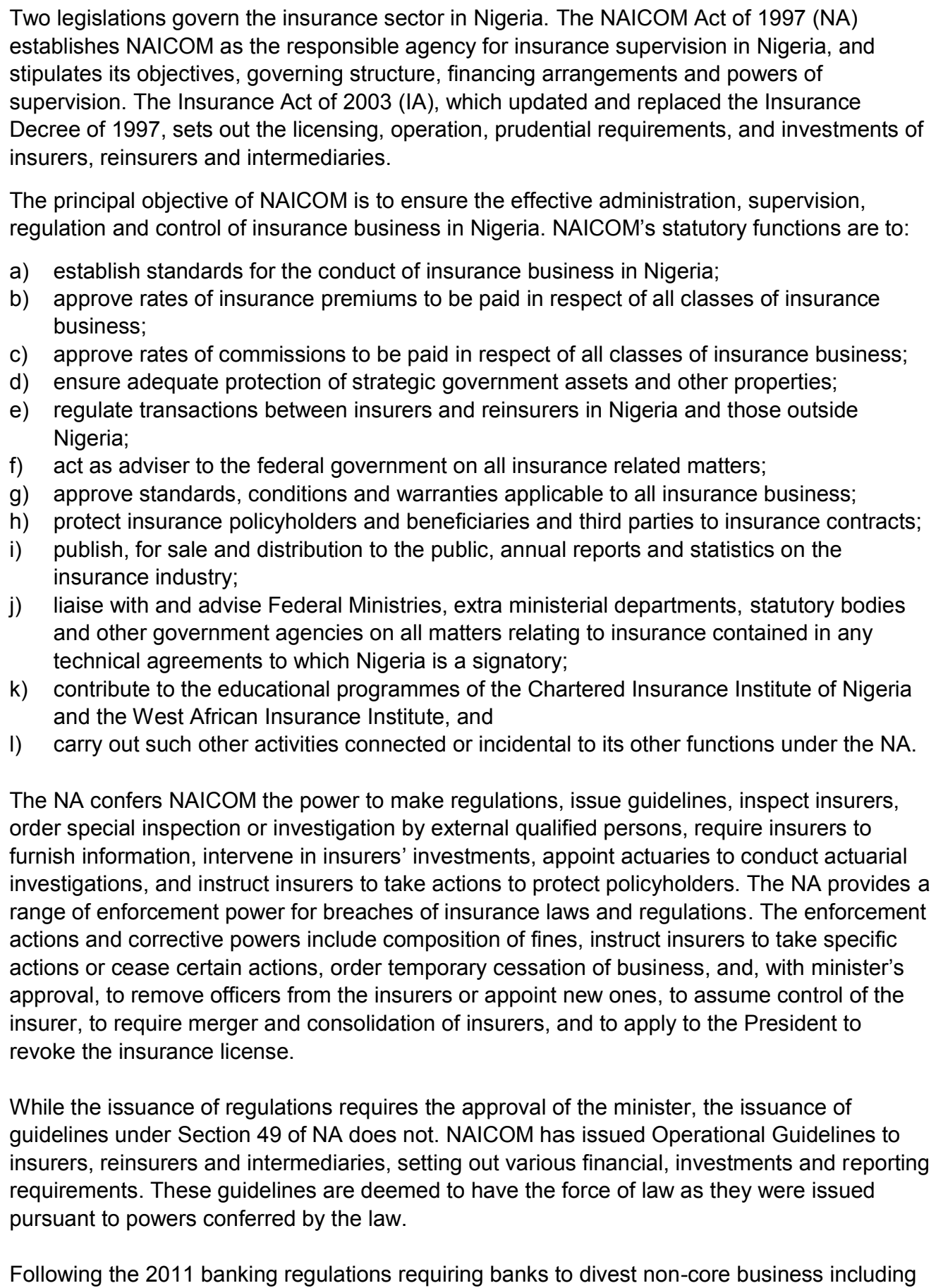 \\
\hline
\end{tabular}




\begin{tabular}{|c|c|}
\hline & $\begin{array}{l}\text { insurance by April 2012, five financial holding companies were created to own separate } \\
\text { banking and insurance entities. Relevant authorities are studying the appropriate supervisory } \\
\text { framework for financial holding companies. }\end{array}$ \\
\hline Assessment & Observed \\
\hline Comments & $\begin{array}{l}\text { The NA identifies NAICOM as the authority responsible for insurance supervision. While the } \\
\text { supervisory objective is clearly defined, it narrowly focuses on the effectiveness of regulation } \\
\text { and supervision. Given the nascent state of the Nigerian insurance market, it is advised that } \\
\text { NAICOM expand the objective to include the creation of a fair, safe and stable insurance } \\
\text { sector for the benefit and protection of policyholders. } \\
\text { NAICOM has the power to issue regulations, with the minister's approval. NAICOM also has } \\
\text { the power to issue guidelines, without the need to obtain minister's approval. NAICOM has } \\
\text { taken the position that guidelines have the force of law, on par with regulations. NAICOM has } \\
\text { issued a number of guidelines on significant prudential matters such as minimum capital, } \\
\text { solvency margin, investment limits, technical provisions, and risk management. NAICOM is } \\
\text { advised to seek legal clarity on the legal force of guidelines. } \\
\text { The power of NAICOM to take corrective and enforcement action is discussed in } \\
\text { ICPs } 10 \text { and } 11 \text {. NAICOM's ability to conduct group-wide supervision is discussed in ICP } 23 \text {. }\end{array}$ \\
\hline ICP 2 & $\begin{array}{l}\text { Supervisor } \\
\text { The supervisor, in the exercise of its functions and powers: } \\
\text { - is operationally independent, accountable and transparent; } \\
\text { - protects confidential information; } \\
\text { - has appropriate legal protection; } \\
\text { - has adequate resources; and } \\
\text { - meets high professional standards. }\end{array}$ \\
\hline Description & $\begin{array}{l}\text { NAICOM is a body corporate established under the NA, governed by a governing board and } \\
\text { managed by a commissioner for insurance (CFI) and two deputy commissioners. The } \\
\text { governing board consists of } 11 \text { members: } \\
\text { - a part time chairman; } \\
\text { - the CFI, and his two deputy commissioners; } \\
\text { - a representative of the Federal Ministry of Finance; } \\
\text { - a representative of the CBN; } \\
\text { - a representative of Chartered Insurance Institute of Nigeria (CIIN); } \\
\text { - a representative of the Federal Ministry of Commerce and Tourism; and } \\
\text { With the exception of the four ex-officio members, board directors are appointed by the Head } \\
\text { of State, Commander-in-Chief of the Armed Forces (i.e., the President) for a four-year term. } \\
\text { The appointees may be removed if the President is satisfied that it is not in the interest of } \\
\text { NAICOM for the person to continue in office, or on grounds of misconduct or inability to } \\
\text { perform his duties. Removal must be made public, although the reasons for removal need not } \\
\text { be disclosed. The appointment may be renewed for another four-year term, but no more. } \\
\text { (Deputy commissioners' term of office is } 5+5 \text {. Their term of appointment as directors coincides }\end{array}$ \\
\hline
\end{tabular}

\footnotetext{
${ }^{7}$ For example, the revised minimum paid-up capital requirement contained in a 2005 guideline is in contradiction of the amounts specified in the primary legislation. Without legal certainty of the enforceability of guidelines, insurers could challenge the new capital requirements. In fact, even if the guidelines have the force of law, they cannot contradict the provisions in the primary legislation.
} 
with their term of office, instead of the $4+4$ for the other directors.)

There is an Internal Audit Unit that reports to the CFI. In addition, Section 23(2) of NA requires the proper record-keeping and accounts to be audited by auditors appointed by NAICOM from an approved list of auditors, in accordance with the guidelines issued by the Auditor General of Nigeria.

NAICOM has 155 staff as at September 1,2012, most of whom have university degrees and some have professional qualifications in insurance, accounting, and law. Most are deployed in six directorates:

- Inspectorate (36 staff): responsible for on-site inspection of insurers, reinsurers and intermediaries, and intervention.

- Authorization and Policy (20 staff): responsible for licensing, and supervisory policies and regulations.

- Supervision (14 staff): responsible for off-site financial analysis, and assessment of levy.

- Research, Statistics \& IT (19 staff).

- Finance \& Accounts (16 staff).

- Administration \& Human Resources (21 staff).

Another 25 staff are involved in internal audit, legal, corporate strategy and corporate affairs.

There are established procedures to make supervisory decisions and to escalate issues when necessary.

The financial resources of NAICOM are based primarily upon an industry levy of:

- 1 percent of gross premiums on insurers,

- 1 percent levy on commissions of insurance brokers, and

- 1 percent levy on gross fees of loss adjusters.

Other sources of financial resources include "such sums as the federal government assigns to $\mathrm{it}^{\prime \prime}$, fines and financial penalties imposed on regulated entities, investment income, and "all sums of money accruing to the Commission by way of gifts, testamentary dispositions and endowments and contributions from any other source whatsoever."

The federal funding is determined annually mainly based on equivalent salary cost on civil service pay scale. 22 percent of NAICOM's operating revenue of $\$ 2,387$ million in 2010 was from government (17 percent for 2011). There was an operating surplus in 2011.

NAICOM may also, within and outside Nigeria, accept gifts of land, money or other property or things upon terms and conditions as may be specified by the person or organization making the gift $^{10}$, provided such terms and conditions are consistent with its aims and objectives. ${ }^{11}$ NAICOM has accepted gifts in the past, mainly in the form of advisory services and technical assistance from individuals or organizations, either in the form of service-in-kind or financial funding.

50 percent of total revenue applies to NAICOM's operation, 30 percent goes to an education fund, and the remaining 20 percent goes to a security and development fund. The education fund provides funding to insurance education institutions. Once the annual budget is approved by the minister for finance, NAICOM has discretion in the allocation of resources.

NAICOM staff are considered public servants, outside of the civil service structure.

\footnotetext{
${ }^{8}$ NAICOM Act 1997, Section 16 (1) (a).

${ }^{9}$ NAICOM Act 1997, Section 16 (1) (f).

${ }^{10}$ NAICOM Act 1997, Section $22(1)$.

${ }^{11}$ NAICOM Act 1997, Section 22 (2).
} 
NAICOM is able to set its salary package that is comparable with the insurance industry and other regulatory institutions in Nigeria. While it has operational autonomy in respect of its expenditure, NAICOM needs to justify its ability to pay the proposed salaries to the National Salaries, Income and Wages Commission, which is the government agency responsible for approval of remuneration in the public sector. According to NAICOM, its proposed remuneration has never been denied, nor does it have difficulty in attracting quality staff, although it is challenging to find individuals with relevant technical knowledge, which is an industry-wide issue.

Certain supervisory actions are subject to minister's approval, such as removing and appointing officers of insurers, taking control of the insurer, requiring insurers to merge, and to apply to the President to revoke license of a failing insurer. All regulatory actions may be challenged in court. The minister's approving power over budget and certain supervisory actions undermines the supervisor's independence, although there is no evidence of undue political interference in NAICOM's performance of its duties.

NA requires inspections to be conducted under condition of confidentiality. Confidential information collected may not be published without the consent of the person who supplied the information. Conditions of service require NAICOM staff to observe confidentiality. ${ }^{12}$ Due to a shortage of experienced inspectors, NAICOM engages outside consultants to participate in its on-site inspections. All consultants engaged by NAICOM are required to sign confidentially agreements.

NAICOM staff are bound by its Code of Conduct, which requires a staff member not to put himself in a position where his personal interest conflicts with his duties and responsibilities.

The Protection of Public Officers Act protects NAICOM staff from being liable for performing their duties in good faith.

Regulatory requirements are published on the NAICOM website. NAICOM reviews the regulatory guidelines, reporting format and disclosure requirements periodically. No written requirements or procedures are in place on public consultation on regulatory changes. In practice, however, NAICOM consults the industry on material changes to the regulations and supervisory practices.

NAICOM publishes an annual report on its website that highlights its activities and provides audited accounts. In additional, NAICOM publishes annually the Nigeria Insurance Statistics and Directory, which lists all licensed entities and provides some aggregate data on the life and non-life insurance industry.

Assessment $\quad$ Largely observed

Comments

The statutory responsibilities of NAICOM are clearly established under legislation. NAICOM relies mainly on industry levy for its financial resources, which allows it to have the independence in setting its own salary levels, despite it having to seek approval of the National Salaries, Income and Wages Commission.

Ministerial approval is required for stronger preventive and enforcement actions, such as removing of officers, or taking control of insurers. To enhance operational independence and to facilitate timely supervisory action, NAICOM should be the final authority in exercising its supervisory powers for operational matters, such as appointment and dismissal of control

\footnotetext{
12 "As an employee of the Commission, staff will acquire certain confidential information relating to trade secrets and/or confidential information of the Commission and that it is fair and reasonably necessary for the protection of the Commission's business and propriety interest that staff should be restrained from competing with the Commission for the duration of the employment agreement."
} 


\begin{tabular}{|c|c|}
\hline & $\begin{array}{l}\text { positions. } \\
\text { NAICOM has introduced many needed improvements to its regulatory and supervisory regime: } \\
\text { the recapitalization in } 2005 \text {, the introduction of corporate governance code in } 2009 \text { and risk } \\
\text { management framework in } 2012 \text {, the adoption of IFRS in } 2012 \text { and the proposed transition to } \\
\text { risk-based supervision. Adequate skills and knowledge are essential to effective } \\
\text { implementation of these new initiatives. } \\
\text { While the use of external consultants is a welcome stop-gap measure to supplement specialist } \\
\text { knowledge of a supervisor, NAICOM appears to engage external consultants in routine on-site } \\
\text { inspections. Since inspection is an integral part of supervisory function, NAICOM should strive } \\
\text { to strengthen its human capital, so that it will not rely on third-party consultants to carry out } \\
\text { routine on-site inspections. (Also see ICP 9.) }\end{array}$ \\
\hline ICP 3 & $\begin{array}{l}\text { Information Exchange and Confidentiality Requirements } \\
\text { The supervisor exchanges information with other relevant supervisors and authorities subject } \\
\text { to confidentiality, purpose and use requirements. }\end{array}$ \\
\hline Description & $\begin{array}{l}\text { NAICOM has power to require insurers to submit information and to obtain information during } \\
\text { on-site inspections on a legal-entity basis. However, NAICOM's power to exchange } \\
\text { information with other relevant supervisors is unclear. NAICOM has relied on a wide } \\
\text { interpretation of Section 8(f) of NA to exchange information: "(The Commission shall have } \\
\text { power to) do such other things as are necessary for the successful performance of its } \\
\text { functions under this Decree." } \\
\text { Nationally, NAICOM is a member of the Financial Services Regulation Coordinating } \\
\text { Committee (FSRCC). Established in } 1994 \text { by CBN, FSRCC coordinates financial sector } \\
\text { regulatory and supervisory activities in Nigeria, with a view to reduce the information gap and } \\
\text { opportunity for regulatory arbitrage. FSRCC meets quarterly. Its six members are: } \\
\text { 1. the Governor of CBN (Chairman); } \\
\text { 2. the Managing Director, Nigeria Deposit Insurance Corporation; } \\
\text { 3. the Director-General, Securities and Exchange Commission; } \\
\text { 4. the CFI, NAICOM; } \\
5 . \quad \text { the Registrar-General, Corporate Affairs Commission; and } \\
6 . \quad \text { a representative of the Federal Ministry of Finance not below the rank of a director. } \\
\text { The framework for coordination is set out in a multilateral MOU. } \\
\text { Internationally, NAICOM has concluded one MOU with a foreign regulator in April 2012, and is } \\
\text { actively working on developing MOUs with several other supervisors in Africa, primarily where } \\
\text { there are parent entities or branches/subsidiaries of Nigerian insurers. NAICOM intends to } \\
\text { become a signatory to the IAIS Multilateral MOU. MOUs are not a prerequisite to exchange } \\
\text { supervisory information. } \\
\text { NAICOM takes steps in the context of agreeing MOUs to ensure that information disclosed is } \\
\text { treated as confidential. } \\
\text { In the absence of an MOU, there are no established procedures in assessing a request for } \\
\text { information. Each request is dealt with as it is received. } \\
\text { NAICOM leverages on the College of Banking Supervisors under the West Africa Monetary } \\
\text { Zone to obtain and exchange insurance market information across the West Africa } \\
\text { jurisdictions. }\end{array}$ \\
\hline Assessment & Largely observed \\
\hline Comments & $\begin{array}{l}\text { Legislation does not provide explicit power for NAICOM to exchange information with relevant } \\
\text { regulators. In practice, NAICOM exchanges information with other national regulators regularly } \\
\text { through the FSRCC. It has recently concluded an information exchange MOU with Ghana and } \\
\text { is in the process of pursuing MOUs with Kenya, Gambia, South Africa and Uganda. For legal }\end{array}$ \\
\hline
\end{tabular}




\begin{tabular}{|c|c|}
\hline & $\begin{array}{l}\text { clarity, the NA should be amended to give NAICOM explicit power to exchange supervisory } \\
\text { information subject to appropriate confidentiality, purpose and use safeguards. NAICOM is } \\
\text { encouraged to accede to the IAIS MMOU. } \\
\text { NAICOM should also establish procedures for handling requests for information in the } \\
\text { absence of an MOU to ensure consistent assessment of such requests and safeguarding } \\
\text { confidentiality of information. }\end{array}$ \\
\hline ICP 4 & $\begin{array}{l}\text { Licensing } \\
\text { A legal entity which intends to engage in insurance activities must be licensed before it can } \\
\text { operate within a jurisdiction. The requirements and procedures for licensing must be clear, } \\
\text { objective and public, and be consistently applied. }\end{array}$ \\
\hline Description & 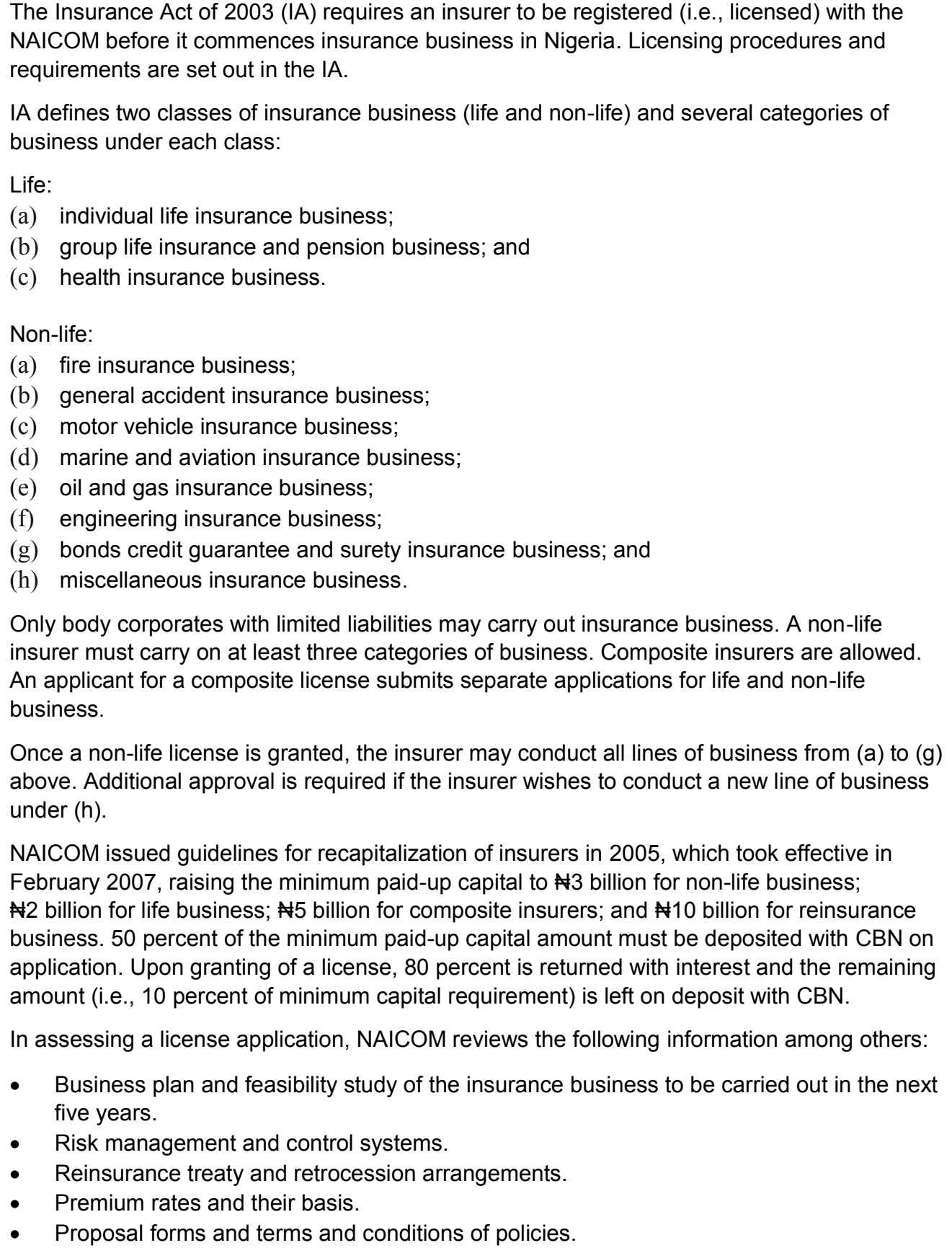 \\
\hline
\end{tabular}




\begin{tabular}{|c|c|}
\hline & $\begin{array}{l}\text { - Credentials of the proposed CEO and directors. } \\
\text { NAICOM grants or rejects a license application within } 60 \text { days. Grounds for rejection are } \\
\text { communicated to the applicant. The rejected applicant may appeal to the minister for finance } \\
\text { within } 30 \text { days of receipt of the rejection. The minister responds to the appeal within } 60 \text { days. } \\
\text { A denial of the appeal is gazetted for public notice. } \\
\text { NAICOM has the power under IA to impose conditions on licenses. However, NAICOM has } \\
\text { not done so in practice. } \\
\text { Operational Guidelines require an insurer or reinsurer intending to establish an offshore } \\
\text { operation to seek approval from NAICOM. NAICOM does not allow cross border activities } \\
\text { without physical presence. }\end{array}$ \\
\hline Assessment & Largely observed \\
\hline Comments & $\begin{array}{l}\text { The IA defines the insurance activities to be licensed, prohibits unlicensed insurance activities, } \\
\text { defines the permissible legal structure of insurers and specifies the licensing requirements and } \\
\text { procedures. License applications are processed in a timely manner. NAICOM discloses } \\
\text { grounds for rejection and rejected applicants may appeal the decision to the minister. NAICOM } \\
\text { has the power to impose conditions or restrictions on a license, although this has not been } \\
\text { done in practice. } \\
\text { In addition to the current licensing requirements, NAICOM is advised to consider the } \\
\text { applicant's corporate governance framework and its group structure to ensure it is not too } \\
\text { complex to be effectively supervised. } \\
\text { Currently, a non-life insurer is permitted to conduct all lines of business, regardless of the lines } \\
\text { of business proposed at the licensing stage. To ensure that insurers have the necessary } \\
\text { financial resources and competence in writing business, NAICOM is advised to consider } \\
\text { granting licenses by lines of business. }\end{array}$ \\
\hline ICP 5 & $\begin{array}{l}\text { Suitability of Persons } \\
\text { The supervisor requires Board members, senior management, key persons in control } \\
\text { functions, and significant owners of an insurer to be and remain suitable to fulfil their } \\
\text { respective roles. }\end{array}$ \\
\hline Description & $\begin{array}{l}\text { Section } 12 \text { of IA stipulates that no insurer should appoint or employ a director, CEO, branch } \\
\text { manager or company secretary if he: } \\
\text { - } \quad \text { is of unsound mind, or is incapable of carrying out his duties as result of ill health; } \\
\text { - } \quad \text { is convicted of any offence involving dishonesty or fraud; } \\
\text { - } \quad \text { is not a fit and proper person for the position; } \\
\text { - } \quad \text { in the case of a person with professional qualification, has been disqualified or suspended } \\
\text { from practicing his profession in Nigeria; } \\
\text { - has been a director of or manager of a financial institution whose license to operate was } \\
\text { cancelled or whose business has been wound-up; } \\
\text { is a person whose appointment with a financial institution has been terminated or who has } \\
\text { been dismissed for reason of fraud or dishonesty; or } \\
\text { has been convicted by a court or tribunal of an offence in the nature of criminal } \\
\text { misappropriation of funds or breach of trust or cheating. } \\
\text { As a practice, NAICOM asks new directors to file a personal history statement with NAICOM. } \\
\text { NAICOM checks the statements to make sure they have not worked in a failed company, and } \\
\text { do not have directorships in more than one similar company to avoid conflict of interest. } \\
\text { Appointment of CEO is required to be approved (s13 of IA). Upon application, NAICOM } \\
\text { checks with other domestic regulators for negative comments, with the police for any criminal }\end{array}$ \\
\hline
\end{tabular}




\begin{tabular}{|c|c|}
\hline & $\begin{array}{l}\text { records, and with the last employer to ascertain the circumstances of leaving employment. } \\
\text { Insurance legislation does not require significant owners to be suitable. While a change in } \\
\text { control exceeding } 25 \text { percent requires NAICOM approval, NAICOM only verifies source of } \\
\text { funding for anti-money laundering purposes. } \\
\text { No suitability requirements for key people in control positions have been set in the IA or } \\
\text { guidelines. }\end{array}$ \\
\hline Assessment & Partly observed \\
\hline Comments & $\begin{array}{l}\text { In addition to directors, CEO, branch managers and company secretary, NAICOM should also } \\
\text { ensure that significant owners and key persons in control positions are suitable. } \\
\text { Currently, NAICOM approves the appointment of CEO, and asks new directors to submit } \\
\text { Personal History Statement. The board of directors is ultimately responsible and accountable } \\
\text { for an insurer. To ascertain that insurers are managed by suitable persons, NAICOM should } \\
\text { consider explicitly approving the appointment of directors, on par with the appointment of } \\
\text { CEOs. Likewise, NAICOM should ensure the suitability of heads of key control positions by } \\
\text { requiring their appointments to be explicitly approved. } \\
\text { The suitability test that NAICOM currently carries out is negative confirmation of criminal and } \\
\text { supervisory indicators. NAICOM is advised to include competence, financial and other } \\
\text { indicators in assessing the individual's suitability. } \\
\text { To ensure continued suitability on an ongoing basis, NAICOM should formalize the existing } \\
\text { practice of subjecting newly appointed directors to a suitability test by requiring insurers to } \\
\text { report any changes in board membership to NAICOM. This should be extended to include key } \\
\text { persons in control positions as well. }\end{array}$ \\
\hline ICP 6 & $\begin{array}{l}\text { Changes in Control and Portfolio Transfers } \\
\text { Supervisory approval is required for proposals to acquire significant ownership or an interest in } \\
\text { an insurer that results in that person (legal or natural), directly or indirectly, alone or with an } \\
\text { associate, exercising control over the insurer. The same applies to portfolio transfers or } \\
\text { mergers of insurers. }\end{array}$ \\
\hline Description & $\begin{array}{l}\text { Section 30(1) of IA requires an insurer to seek approval of NAICOM or sanction of court } \\
\text { before it may (a) amalgamate with another insurer, (b) transfer any part of its business to } \\
\text { another insurer, or (c) acquire any business from another insurer. } \\
\text { Before an application is made to NAICOM for approval of amalgamation, portfolio transfer or } \\
\text { acquisition, the insurer should notify NAICOM and publish a notice of intention to make the } \\
\text { application together with a statement of the nature of the amalgamation, transfer or } \\
\text { acquisition in at least five national newspapers at least three months before the application is } \\
\text { made. (Section 30(4).) } \\
\text { NAICOM may reject the request to amalgamate, transfer or acquire if more than } 1 / 5 \text { of the } \\
\text { affected policyholders object to the transaction. After the amalgamation, transfer or } \\
\text { acquisition is approved, policyholders are not deemed to have abandoned their claims } \\
\text { against the original insurer. } \\
\text { Any insurer from whom the business has been transferred may not be licensed to undertake } \\
\text { the same categories of insurance business for five years. } \\
\text { In additional to the provisions in IA, the Operational Guidelines require a change in ownership } \\
\text { of an insurer resulting in any individual controlling (directly or indirectly) up to } 25 \text { percent of its } \\
\text { shares must receive a "no objection letter" from NAICOM before such transactions are } \\
\text { concluded. } \\
\text { In assessing all changes in control transactions (amalgamation, transfer/acquisition of }\end{array}$ \\
\hline
\end{tabular}




\begin{tabular}{|c|c|}
\hline & $\begin{array}{l}\text { portfolio, change in significant ownership), NAICOM verifies the source of funding for anti- } \\
\text { money laundering purposes. It does not perform any prudential or suitability verification. }\end{array}$ \\
\hline Assessment & Partly observed \\
\hline Comments & $\begin{array}{l}\text { Current legislation addresses the situations where (a) an insurer amalgamates itself with } \\
\text { another insurer, (b) an insurer transfers all or part of its business to another insurer, or (c) an } \\
\text { insurer acquire a portfolio of insurance business from another insurer. It does not address the } \\
\text { situation where a person gains control of an insurer through other means, such as acquiring } \\
\text { shares of the insurer. The Operational Guidelines bridge the gap by requiring "all changes in } \\
\text { ownership of any insurance and re-insurance company that will entitle any individual to control } \\
\text { (directly or indirectly) up to } 25 \text { percent holding of its shares must be cleared with the } \\
\text { Commission before such transactions are concluded." } \\
\text { It is not clear that the } 25 \text { percent change in control requirement in the Operational Guidelines } \\
\text { is enforceable, as it is not derived from any provisions in the primary legislation. NAICOM } \\
\text { should seek amendment of the primary legislation to solidify its supervisory intention. At the } \\
\text { same time, NAICOM should clarify (a) whether the threshold shareholding is based on issued } \\
\text { shares or voting shares, and (b) it applies to both acquisition and disposal of shares. } \\
\text { NAICOM may wish to consider progressive thresholds, rather than a single-point threshold. } \\
\text { For example, an insurer should notify NAICOM when an individual gains control of } 5 \text { percent, } \\
10 \text { percent, and } 20 \text { percent of its voting shares. } \\
\text { NAICOM should be able to identify the intended beneficial owner, and evaluate the application } \\
\text { as if it were an application for a new license, taking into account how policyholders' interests } \\
\text { might be affected. }\end{array}$ \\
\hline ICP 7 & $\begin{array}{l}\text { Corporate Governance } \\
\text { The supervisor requires insurers to establish and implement a corporate governance } \\
\text { framework which provides for sound and prudent management and oversight of the insurer's } \\
\text { business and adequately recognizes and protects the interests of policyholders. }\end{array}$ \\
\hline Description & $\begin{array}{l}\text { NAICOM has issued a Code of Good Corporate Governance (CGCG) in } 2009 \text { applicable to } \\
\text { insurers, reinsurers and intermediaries. It is a code of best practice and is not binding. } \\
\text { However, NAICOM has incorporated CGCG in its inspection program, and uses moral suasion } \\
\text { to encourage insurers to comply with CGCG. } \\
\text { Since all insurers and reinsurers are body corporates, they are also subject to relevant } \\
\text { requirements in the Companies and Allied Matters Act 1990. The } 22 \text { insurers listed on the } \\
\text { Nigerian Stock Exchange are further subject to the requirements applicable to listed } \\
\text { companies. } \\
\text { The CGCG covers the following areas. } \\
\text { a) Conduct of the Board of Directors: } \\
\text { Balance of Power and Authority } \\
\text { - Chairman shall be non-executive. } \\
\text { - No one person shall occupy the position of chairman and Chief Executive Officer at the } \\
\text { same time. } \\
\text { No two members of the same extended family shall occupy the position of the Chairman } \\
\text { and Managing Director/Chief Executive. } \\
\text { Qualification of Board Members } \\
\text { - Relevant experience in and knowledge of the insurance industry. } \\
\text { - Having integrity, willingness and ability to be independent and objective as well as to }\end{array}$ \\
\hline
\end{tabular}


serve actively as a director.

- Limited insider relationships and links with competitors.

- Track record of competence in discharging duties as a director.

- NAICOM shall arrange relevant training on insurance principles and practice, director's responsibilities and liabilities.

\section{Composition of the Board}

- The Board should be no less than seven and not more than 15 members.

- The board should consist of not more than 40 percent of Executive Directors, and should include at least one independent director.

- The independent director is critical in the evaluation of the performance of the board and management; mediate where interests of management, the company and its shareholders may diverge such as executive remuneration, succession planning, changes of corporate control, take-over defences, large acquisitions and audit function.

- Non-executive directors are appointed no more than three terms of three years each.

- Any individual taking major action in the running of the company must either be a member of the Board, the management or paid consultant.

Responsibilities of the Board

- Review corporate strategy, major plans of actions, risk policy, business plans, setting performance objectives, monitoring implementation and corporate performance and overseeing major capital expenditures and acquisitions.

- Select, compensate, monitor and when necessary, replace key executives and oversee succession planning.

- Monitor the effectiveness of the governance practices under which it operates and make changes as may be necessary.

- Ensure the integrity of the accounting and financing reporting systems, including the independent audit and that appropriate systems of control are in place, in particular, systems for monitoring risk, financial control and compliance with the law.

- Monitor and manage potential conflicts of interest of management, board members and shareholders, including misuse of corporate assets and abuse in related party transactions.

- $\quad$ Supervise and monitor the execution of policies and provide direction for the management.

- Monitor potential risks within the company including recognizing and encouraging honest whistle blowing.

- Oversee the process of disclosure and communication in the company.

\section{Performance of the Board}

Directors are expected to preserve and enhance the shareholders' value. There shall be annual board performance appraisal to be carried out by an external consultant to be appointed by the shareholders. The assessment report is forwarded to NAICOM.

\section{Conflict of Interest}

To ensure and maintain high ethical standards for the conduct of insurance business, each director and employee of an insurance company shall formally disclose to the board or shareholders his/her interest in any: 
- Insurance Broking firm

- Loss Adjusting firm

- Actuarial firm

- Insurance \& reinsurance company

- Accounting/taxation firm/audit firms

- Legal firms

Payment of commissions and/or fees to insurance intermediaries in which the CEO, a director or an employee has interest shall be fully documented and the interest therein fully disclosed to the board and shareholders.

\section{Frequency and Attendance of Meetings}

The Board shall meet not less than four times in a year. Each member is expected to attend not less than 75 percent of the meetings annually.

b) Board Committees: The board should have the following committees:-

- Finance and General Purposes Committee

- Investment Committee

- Enterprise Risk Management Committee

- Audit and Compliance Committee.

- Establishment and Governance Committee, of which the Independent Director is a member.

c) Duties of Audit and Compliance Committee: The Committee is to be headed by an Independent Director, with no more than one Executive Director, and at least two of the nonExecutive Directors should have requisite knowledge of accounting, financial analysis and financial reporting. Duties include:

- Provide oversight functions with regard to both the company's financial statements and its internal control and risk management functions.

- Review the terms of engagement and recommend the appointment or re-appointment and compensation of External Auditors.

- Appointment of external auditor is subject to NAICOM approval, for a term no longer than five years.

- Review the procedure put in place to encourage honest whistle blowing.

d) Internal Audit: Every insurer/reinsurer must have an Internal Audit Unit, headed by a professionally qualified accountant not below the rank of an AGM or its equivalent. The Head of Internal Audit Unit should be highly competent, objective and with high integrity. The Head of the Internal Audit Unit shall report directly to the MD/CEO but a copy of his Audit Report shall be forwarded to the Audit Committee on a regular basis. Internal audit report states the responsibility of management for establishing and maintaining an adequate internal control structure and procedure for financial reporting. The internal audit report is filed with NAICOM every quarter, and is included in the Annual Report.

e) Shareholders' Rights:

- Shareholders should be encouraged to attend AGMs to exercise their rights including electing and removing board members.

- Information communicated to shareholders should be understandable and accessible on a timely and regular basis.

- Shareholders have a right to make their views known on the remuneration policy for board members and key executives of the company.

- Receiving of notices of meetings and other relevant information/documents at least 21 clear days before meetings, except in cases of EGMs. 
- The company should provide for the position of a minority shareholder on the Board.

e) Disclosure: disclosure and reporting requirements should be in line with NAICOM guidelines. Furthermore, the annual accounts should include the following:

- Information about each shareholder who owns directly or indirectly a minimum of 5 percent of shares of the company as well as the shareholders who control the company when acting in concert.

- Show manner of compliance with, or explain any deviation from applicable corporate governance codes.

- Disclose Board Meeting attendance record of members.

- Disclose the major items that have been estimated and any deviation from applicable accounting, auditing and corporate governance standards.

- Disclose related party transactions in accordance with International Financial Reporting Standards (IFRS).

- Disclose all contraventions on which penalties have been imposed by NAICOM and/or any other regulatory/supervisory body in any accounting year.

External auditors issue a statement on the compliance with the Code, as part of the Annual Report of Listed Companies.

Corporate governance is part of NAICOM's on-site inspection program. Even though CGCG is not compulsory, NAICOM uses moral suasion to encourage insurers to adhere to CGCG.

\begin{tabular}{|c|c|}
\hline Assessment & Largely observed \\
\hline Comments & $\begin{array}{l}\text { A voluntary code of corporate governance has been in place since 2009, establishing the } \\
\text { governance structure for insurers and intermediaries. } \\
\text { Since this is a relatively new code in Nigeria, there are several fine-tuning changes that } \\
\text { NAICOM may wish to consider to improve the code: } \\
\text { - Various regulators have issued corporate governance codes: the Corporate Affairs } \\
\text { Commission, the Stock Exchange, NAICOM and CBN. These regulators should discuss } \\
\text { and consider a unified code to avoid market confusion. } \\
\text { - Independent directors are expected to have a "critical" role in evaluation of the board's } \\
\text { performance. At the same time, CGCG requires an outside consultant to perform such } \\
\text { evaluation. Clarification should be given regarding the role of independent directors in } \\
\text { evaluation of board performance, relative to the external consultant. } \\
\text { - Section } 5.04 \text { (xi) of CGCG states: "Any individual taking major action in the running of the } \\
\text { company must either be a member of the Board, the management or paid consultant." } \\
\text { The role of paid consultant in the running of the company is unclear. } \\
\text { - Responsibility of the board should be to "establish" strategy, not merely review. } \\
\text { CGCG states that the appointment of the external auditor is subject to NAICOM approval. } \\
\text { NAICOM has not explicitly required insurers to do so. } \\
\text { CGCG advocates disclosure of conflict of interest disclosure by all employees to the } \\
\text { board or shareholders. To avoid the board being inundated with declarations, such } \\
\text { disclosure should be made to management, except in the case of senior management } \\
\text { and key people in control positions. } \\
\text { Other than the audit committee, the roles of other board committees are not specified. } \\
\text { CGCG could be expanded to require each board committee to have terms of reference. } \\
\text { CGCG indicates that head of internal audit is to report to the MD/CEO. Internal audit } \\
\text { should have a direct reporting line to the audit committee of the board to be consistent } \\
\text { with international best practice. }\end{array}$ \\
\hline
\end{tabular}

NAICOM informed that the FRC is leading a project to unify the various codes of corporate governance. 


\begin{tabular}{|c|c|}
\hline & $\begin{array}{l}\text { In approving the appointment of directors, NAICOM should take into account the mix of } \\
\text { knowledge, skills and expertise of directors. To ensure greater independence of the boards, } \\
\text { the number of independent directors should be increased from the current number of one. }\end{array}$ \\
\hline ICP 8 & $\begin{array}{l}\text { Risk Management and Internal Controls } \\
\text { The supervisor requires an insurer to have, as part of its overall corporate governance } \\
\text { framework, effective systems of risk management and internal controls, including effective } \\
\text { functions for risk management, compliance, actuarial matters, and internal audit. }\end{array}$ \\
\hline Description & 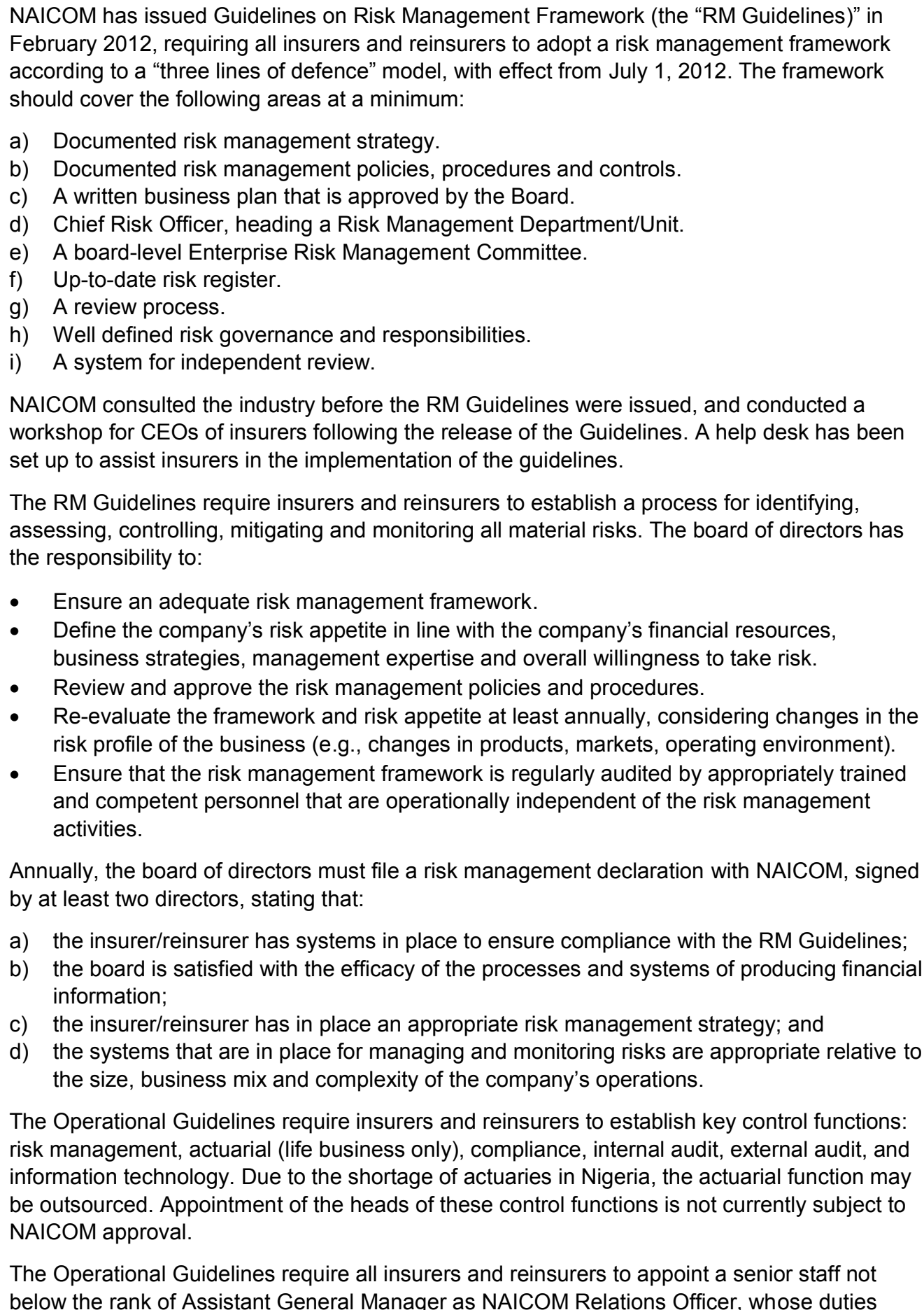 \\
\hline
\end{tabular}

\section{CInternational Monetary Fund. Not for Redistribution}


include:

- Vetting of all returns to NAICOM.

- Ensuring compliance with all statutory requirements.

- Ensuring effective dissemination of directives and policy changes as may be contained in administrative letters, circulars, guidelines and other relevant statutory documents issued by NAICOM from time to time.

The NAICOM Relations Officer reports to the CEO and may report to NAICOM any observation or conducts that are inconsistent with the statutory provisions and/or standard practice within the insurance industry.

The internal audit unit is to evaluate the adequacy and effectiveness of the insurer's internal controls, issue recommendations and ensure that deficiencies are remedied. An internal audit report is filed with NAICOM every quarter.

While the RM Guidelines identify outsourcing of staff as one element of operational risk, there are no explicit requirements on the management oversight of the outsourced activities.

\begin{tabular}{|c|c|}
\hline Assessment & Largely observed \\
\hline Comments & $\begin{array}{l}\text { NAICOM has issued comprehensive RM Guidelines, requiring insurers and reinsurers to } \\
\text { establish effective risk management and internal controls with effect from July 2012. The } \\
\text { board of directors is required to submit an annual declaration to NAICOM, certifying the } \\
\text { insurer's compliance with the RM Guidelines and that the board is satisfied with the efficacy of } \\
\text { the process and systems of producing financial information. NAICOM has conducted training } \\
\text { for the industry and its staff to ensure consistent understanding of the requirements. NAICOM } \\
\text { is in the process of revising its inspection manual to include the new RM Guidelines. Given the } \\
\text { newness of the framework, the effectiveness of its implementation is yet to be seen. } \\
\text { NAICOM currently does not address the insurer's accountability for outsourced activities. Due } \\
\text { to the shortage of professionals in the market, outsourcing is not uncommon. Therefore, } \\
\text { NAICOM should clarify the insurer's responsibility when outsourcing material functions, } \\
\text { including selecting the service provider, approving procedures, service contract, review of } \\
\text { contract, and accountability for outsourced functions. } \\
\text { NAICOM should also expand on the requirement for insurers to have disaster } \\
\text { recovery/business continuity plan, by (a) specifying the required recovery time based on } \\
\text { functional criticality and (b) requiring periodic testing of the business continuity plan. }\end{array}$ \\
\hline ICP 9 & $\begin{array}{l}\text { Supervisory Review and Reporting } \\
\text { The supervisor has an integrated, risk-based system of supervision that uses both off-site } \\
\text { monitoring and on-site inspections to examine the business of each insurer, evaluate its } \\
\text { condition, the quality and effectiveness of its Board and Senior Management and compliance } \\
\text { with legislation and requirements. The supervisor obtains the necessary supervisory } \\
\text { information to conduct effective supervision of insurers and evaluate the insurance market. }\end{array}$ \\
\hline
\end{tabular}

Description

\section{Off-site supervision}

Operational Guidelines require insurers and reinsurers to submit audited annual accounts and returns within 6 months after the end of the financial year, and quarterly returns within 30 days after the end of the quarter to NAICOM. A penalty of $\$ 5,000$ per day is applicable to the late filing of annual returns. Annual and quarterly returns are signed off by directors and/or senior management. These returns are on a legal entity basis; no returns on a group-wide basis are required.

14 staff in the Supervision Department is responsible for reviewing the returns, financial statements and other documents. Every three years an actuary's report is required to be submitted by life insurers (not required of non-life insurers). Approval of its annual returns and accounts from NAICOM is required before an insurer/reinsurer may present the financial 
accounts at AGM and distribute dividends to shareholders.

Information Submitted Annually:

a) Audited financial statements and annual returns.

b) Age-analysis of outstanding premium and claims.

c) Schedule of unexpected risk.

d) Current Actuarial Valuation Report for life business.

e) Schedule of Investment with relevant documents.

f) Schedule of personnel returns.

Information Submitted Quarterly:

a) Non-life Business:

i. statement of premium, claims and commissions by lines of business;

ii. statement of management expenses;

iii. quarterly balance sheet;

iv. revenue account; and

v. profit and loss account.

b) Life Business:

i. quarterly revenue account;

ii. quarterly balance sheet;

iii. quarterly statement of in-force business and claims;

iv. quarterly statement of pension business including deposit administration; and

v. profit and loss account.

Upon receipt of the accounts and returns, the off-site supervisors conduct verification of accuracy of financial information, investment limits, and generate various ratios relating to underwriting results and reserves. Ratios are checked against acceptable ranges, based on international experience, due to lack of timely industry benchmarks. Trend analysis of underwriting results is done over the past five years.

Once the financial statements are approved, the insurer/reinsurer publishes its financial statements in at least one newspaper having wide circulation in Nigeria.

NAICOM has plans to enable electronic submission of reports to enable easy analysis of the information for rating of the companies, stress- testing, and benchmarking.

\section{On-site Inspection}

Section 32 of NA allows NAICOM inspectors access to books, accounts, documents and vouchers of insurance institutions. Section 33 of NA requires insurance institutions to provide such documents and explanation for the purpose of inspections. Inspections are conducted under the condition of confidentiality.

There are 36 staff in the Inspectorate Directorate. All but 5 of them are based in Lagos. NA requires inspections to be carried out not less frequently than once every two years. In practice, NAICOM inspects insurers and reinsurers on a two-year cycle, and brokers on a selective basis.

On-site inspection starts with a maiden inspection that is usually conducted about six months after commencement of business. It is to ensure that the approved board and management, share register, suitable premises, proper internal control system, and required books and records are in place.

Routine inspection is conducted once every two years or more frequently if the need arises. Routine inspection covers all aspect of the entity's operations. The duration of routine inspections is one to two months on-site.

Section 35 of NA allows NAICOM to conduct special inspections, with the approval of CFI, if there is evidence of poor financial condition that might threaten the going concern status of an insurance organization. NAICOM may appoint external qualified persons to conduct special inspections. 
To complement comprehensive routine inspections, NAICOM conducts thematic target inspections to focus on a few areas. For example, investments could be targeted for inspection to assess the quality and determine the level of provision to be made for diminution.

NAICOM informed that external consultants are engaged only for special inspections, as provided under the law. Using a small sample between November and December of 2011, NAICOM conducted 16 routine inspections, four special inspections and two targeted inspections. On this basis, external consultants were engaged in four out of 22 inspections. However, a review of three sample inspection files provided by NAICOM indicates that external consultants were involved in two of the three cases: one targeted inspection by two external consultants, and one routine inspection by five NAICOM staff and two external consultants.

NAICOM has an inspection manual to ensure consistency of quality of on-site inspections. The manual covers corporate structure (name, address, major shareholders, paid-up capital), compliance with CGCG, particulars of management staff, policies (premium rates, policy terms and conditions), payment of claims, investments, technical reserves, reinsurance treaties, etc.

Before the planned inspection, the Inspectorate department sends out a visit request letter, with a list of documents the inspectors wish to review as part of the fact finding/knowledge gathering stage. It gives the insurer an idea of the scope of the inspection.

During the inspection, inspectors hold end-of-day de-brief sessions on any issues they have discovered during the day. This helps to quickly resolve and remedy issues. An exit meeting is held at the conclusion of the on-site visit to discuss initial conclusions with a member of senior management.

An inspection report is prepared following the conclusion of the inspection, setting out: (a) the issues identified by the inspectors; (b) the intended outcome that the supervisor seeks for each issue; and (c) the action to be taken to achieve the intended outcome, specifying action to be taken. After being approved by the NAICOM Board, the inspection report is sent to the chairman of the inspected entity, requesting written confirmation that the management will follow actions specified in the report. If the insurer disagrees with the findings, or the proposed remedial actions, the insurer may request for NAICOM's consideration of its reasons for disagreement.

The Inspectorate department follows up on any remedial actions.

While NAICOM has not issued requirements for outsourcing activities, NAICOM relies on its general power in the NA to require any information or records from outsourced functions of the insurer.

NAICOM has issued an exposure draft on risk-based supervision framework in March 2012. The draft outlines the approach to risk-based supervision, without numerical details on how the risk-ratings are to be done. NAICOM needs to develop details, and to train staff in understanding insurance operations and risk management, before the framework can be implemented.

Assessment

Comments
Partly observed

Experience has shown that the audited financial statements may contain serious mistakes. Thus off-site supervisors spend an inordinate amount of time in verifying the accuracy of the audited financial information, crowding out time available for quantitative analysis of the performance of the insurers. NAICOM is advised to collaborate with the FRC to improve the quality of audits, and to take stern action against any insurer and its directors for not having appropriate systems in place to ensure the reliability of financial information, so that resources can be channelled to more strategic supervisory work.

IFRS has been adopted from 2012. The industry's preparedness to produce financial reporting on IFRS may be questionable based on the 2012 quarterly returns. Together with FRC, 


\begin{tabular}{|c|c|}
\hline & $\begin{array}{l}\text { NAICOM should work with the industry to identify the obstacles to the implementation of IFRS. } \\
\text { NAICOM engages external consultants in conducting on-site inspections. Section } 35 \text { of NA } \\
\text { permits the use of consultants in conducting inspections under special circumstances. It is not } \\
\text { apparent that the use of consultants is permitted for routine or targeted inspections. Moreover, } \\
\text { since on-site inspection is an integral part of supervision, enabling supervisors to have } \\
\text { firsthand knowledge of the operations, NAICOM should develop its own supervisory capacity } \\
\text { and use consultants only in specialized fields such as IT risk assessment or forensic } \\
\text { investigations. } \\
\text { Both onsite and offsite supervision is currently compliance driven. With the release of the RM } \\
\text { Guidelines and the impending move to risk-based supervision, NAICOM needs to develop a } \\
\text { comprehensive staff training program on understanding risks, evaluating effectiveness of risk } \\
\text { management and internal controls, and assessing the financial resilience of an insurer. }\end{array}$ \\
\hline ICP 10 & $\begin{array}{l}\text { Preventive and Corrective Measures } \\
\text { The supervisor takes preventive and corrective measures that are timely, suitable and } \\
\text { necessary to achieve the objectives of insurance supervision. }\end{array}$ \\
\hline Description & $\begin{array}{l}\text { In the interest of protecting policyholders, NAICOM has the power to intervene in an insurer's } \\
\text { investments, and to compel information, books, records, and explanations from management. } \\
\text { NAICOM has the general power to instruct an insurer to take such action as it deems } \\
\text { appropriate for the purpose of protecting policyholders against the risk that the insurer may be } \\
\text { unable to meet its liabilities or fulfill the reasonable expectation of policyholders. } \\
\text { In addition, when an insurer is likely to become unable to meet its obligations, NAICOM has } \\
\text { the power to take a range of remedial actions, including issue instruction to: (a) cease new } \\
\text { business, (b) take or cease specific actions, (c) remove officers, (d) remove or appoint } \\
\text { directors, and (e) appoint adviser. Appointment and removal of individuals is subject to the } \\
\text { approval of the minister. } \\
\text { If a situation does not improve, NAICOM may, with minister's approval, to: (a) assume control } \\
\text { of all or part of the insurance operations, or (b) appoint a third party to do so. } \\
\text { Should the insurer's financial resources fall below the minimum paid-up capital requirement, } \\
\text { NAICOM may, with the approval of the minister, apply to the President to revoke the insurance } \\
\text { license. NAICOM may also, with the approval of the minister, order a failing insurance } \\
\text { institution to merge or consolidate with another. } \\
\text { In lieu of applying to the President to revoke the license, NAICOM may cancel the license for } \\
\text { prudential and market conduct reasons. (IA, Section } 8 \text {.) } \\
\text { According to NAICOM's procedure manual on intervention, once it is satisfied that an insurer is } \\
\text { of unsound condition, or has failed to maintain statutory reserves, or has failed to maintain } \\
\text { adequate management control, or has failed generally to comply with laws and regulations, } \\
\text { then NAICOM may take any of the following steps: } \\
\text { - Intervene in the management of the insurer. } \\
\text { - Take over control of the insurer. } \\
\text { - Recommend merger. } \\
\text { - Revoke the license. } \\
\text { The remedial actions that NAICOM has taken in the past include: appoint technical advisers to } \\
\text { advice insurers (cost borne by the insurers); appoint interim management and/or board of } \\
\text { directors; order to cease writing new business; suspend operation; give instructions on } \\
\text { investments; and require capital injection. }\end{array}$ \\
\hline Assessment & Largely observed \\
\hline
\end{tabular}




\begin{tabular}{|c|c|}
\hline Comments & $\begin{array}{l}\text { NAICOM has a wide range of preventive and corrective measures at its disposal under the } \\
\text { legislation. It has exercised its intervention powers in performing its supervisory duties. } \\
\text { However, certain supervisory actions are subject to minister's approval, which may hinder its } \\
\text { ability to take timely action when necessary. To ensure timely action, NAICOM should have } \\
\text { the autonomy to take preventive and corrective action without applying to minister for } \\
\text { approval. } \\
\text { NA provides that NAICOM may, with minister's approval, apply to President to revoke an } \\
\text { insurer's license. IA, on the other hand, provides that NAICOM may cancel the license under } \\
\text { certain circumstances. As there is no practical difference between revocation and cancellation, } \\
\text { NAICOM's power to revoke/cancel a license should be consistent in the two legislations. }\end{array}$ \\
\hline ICP 11 & $\begin{array}{l}\text { Enforcement } \\
\text { The supervisor enforces corrective action and, where needed, imposes sanctions based on } \\
\text { clear and objective criteria that are publicly disclosed. }\end{array}$ \\
\hline Description & 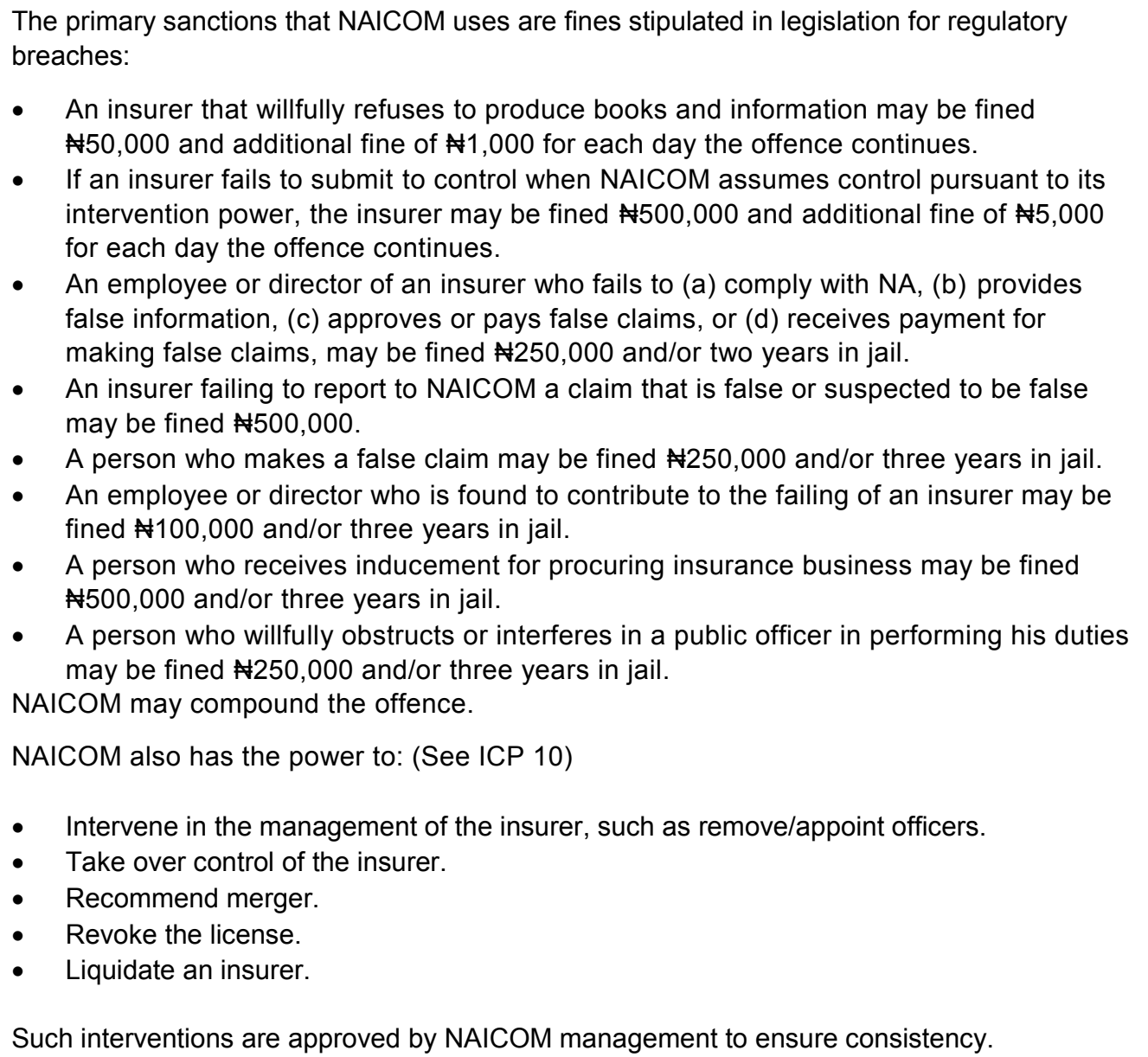 \\
\hline Assessment & Largely observed \\
\hline Comments & $\begin{array}{l}\text { Similar to ICP } 10 \text {, NAICOM has a wide range of enforcement power and it has exercised its } \\
\text { power in performing its supervisory duties. However, certain actions are subject to minister's } \\
\text { approval, which may hinder its ability to take timely action when necessary. To ensure timely } \\
\text { action, NAICOM should have the autonomy to take enforcement action without applying to } \\
\text { minister for approval. }\end{array}$ \\
\hline ICP 12 & Winding-up and Exit from the Market \\
\hline
\end{tabular}




\begin{tabular}{|c|c|}
\hline & $\begin{array}{l}\text { The legislation defines a range of options for the exit of insurance legal entities from the } \\
\text { market. It defines insolvency and establishes the criteria and procedure for dealing with } \\
\text { insolvency of insurance legal entities. In the event of winding-up proceedings of insurance } \\
\text { legal entities, the legal framework gives priority to the protection of policyholders and aims at } \\
\text { minimising disruption to provision of benefits to policyholders. }\end{array}$ \\
\hline Description & $\begin{array}{l}\text { Section } 32 \text { of IA provides that a petition for the winding-up of an insurer may be presented to } \\
\text { the Court either (a) by not less than } 50 \text { policyholders, each of whom holds a policy that has } \\
\text { been in force for not less than three years, on the grounds specified in Section } 408 \text { and } 409 \text { of } \\
\text { the Companies and Allied Matters Act } 1990{ }^{13} \text { or (b) by NAICOM on the grounds that (i) the } \\
\text { insurer's license has been cancelled; or (ii) the insurer cannot be revived despite the } \\
\text { supervisory intervention. } \\
\text { Notwithstanding the provisions of the Companies and Allied Matters Act } 1990 \text { or any other } \\
\text { enactment, the following priority list shall be followed in settling debts owed by the company: } \\
\text { a) liquidation fees; } \\
\text { b) secured creditors; } \\
\text { c) policyholders; } \\
\text { d) other creditors; } \\
\text { e) staff; and } \\
\text { f) shareholders and directors. } \\
\text { A life insurer is prohibited from voluntarily wind-up its business except for the purpose of } \\
\text { effecting an amalgamation, transfer or acquisition. } \\
\text { NAICOM has powers under the IA to cancel an insurer's license in the event of a breach of } \\
\text { solvency requirements. NAICOM may also, under the NA, apply to the President to revoke the } \\
\text { insurer's license. Where the license is cancelled or revoked, the insurer must, within } 14 \text { days, } \\
\text { apply to the Court for an order to wind-up the company and the Court must hear the application } \\
\text { in priority to all other matters. If the insurer fails to apply to the Court within the period specified, } \\
\text { NAICOM may apply to the Court for the winding up of the insurer. } \\
\text { NAICOM has a procedure manual on the process of winding up. }\end{array}$ \\
\hline Assessment & Observed \\
\hline Comments & The procedures for the winding-up and exit of an insurer from the market are clearly set out in \\
\hline
\end{tabular}

${ }^{13} 408$. A company may be wound up by the court if:

(a) the company has by special resolution resolved that the company be wound up by the court;

(b) default is made in delivering the statutory report to the Commission or in holding the statutory meeting;

(c) the number of members is reduced below two;

(d) the company is unable to pay its debts; and

(e) the court is of opinion that it is just and equitable that the company should be wound up.

409. A Company shall be deemed to be unable to pay its debts if -

(a) a creditor, by assignment or otherwise, to whom the company is indebted in a sum exceeding 2,000 then due has served on the company, by leaving it at its registered office or head office, a demand under his hand requiring the company to pay the sum so due, and the company has for three weeks thereafter neglected to pay the sum or to secure or compound for it to the reasonable satisfaction of the creditor; or

(b) execution or other process issued on a judgment, decree or order of any court in favour of a creditor of the company is returned unsatisfied in whole or in part; or

(c) the court, after taking into account any contingent or prospective liability of the company is satisfied that the company is unable to pay its debts. 


\begin{tabular}{|c|c|}
\hline & $\begin{array}{l}\text { legislation. The Court hears the winding-up applications in priority to other matters to avoid a } \\
\text { lengthy legal process. Policyholders have priority claim on an insurer's assets above other } \\
\text { unsecured creditors. And the statutory deposit provides for additional asset safety in a winding } \\
\text { up situation to policyholders. } \\
\text { While it may be appropriate for policyholders to bring legal action against an insurer, the ability } \\
\text { to petition the Court to liquidate an insurer may afford too much power to any } 50 \text { individuals. It } \\
\text { may in fact be detrimental to the public and other policyholders. The power to wind-up an } \\
\text { insurer should be the sole responsibility of the insurance supervisor. It is recommended to } \\
\text { remove this provision from the legislation. }\end{array}$ \\
\hline ICP 13 & $\begin{array}{l}\text { Reinsurance and Other Forms of Risk Transfer } \\
\text { The supervisor sets standards for the use of reinsurance and other forms of risk transfer, } \\
\text { ensuring that insurers adequately control and transparently report their risk transfer } \\
\text { programmes. The supervisor takes into account the nature of reinsurance business when } \\
\text { supervising reinsurers based in its jurisdiction. }\end{array}$ \\
\hline Description & $\begin{array}{l}\text { RM Guidelines require insurers to maintain adequate reinsurance arrangements and treaties. } \\
\text { Insurers must have a documented policy stating: } \\
\text { - } \quad \text { systems for the selection of reinsurance brokers and other reinsurance advisers; } \\
\text { - } \quad \text { systems for selecting and monitoring reinsurance programs; } \\
\text { - } \quad \text { clearly defined managerial responsibilities and controls; } \\
\text { - } \quad \text { for determining all aspects of a reinsurance programme; and } \\
\text { regular basis. } \\
\text { Operational Guidelines require that all reinsurance arrangements be considered and approved } \\
\text { by the board of directors. All reinsurance and retrocession arrangements must be concluded } \\
\text { and a copy filed with NAICOM on or before December } 31 \text { of the preceding year (i.e., } 2012 \\
\text { arrangement should be filed on or before December } 31,2011 \text { ), or December } 15 \text { in the case of } \\
\text { oil and gas business. } \\
\text { NAICOM's review of reinsurance treaties is from the perspective of market development by } \\
\text { retaining, capacity permitting, risks in Nigeria. Specifically, NAICOM verifies that: } \\
\text { - The reinsurance is with local reinsurers licensed by NAICOM as IA requires. } \\
\text { - } \quad \text { Local capacity is exhausted before ceding risks abroad. } \\
\text { - The mandatory } 5 \text { percent cession to Africa Re is met. } \\
\quad \text { In the case of oil and gas business, NAICOM also ensures that the insurer retains at least } \\
5 \text { percent of the risk to avoid fronting. } \\
\text { A foreign reinsurer has a credit rating of at least A- by Standard and Poor or A by AM } \\
\text { Best. } \\
\text { Regulation forbids the reinsurance of certain lines of business including life with foreign } \\
\text { reinsurers, thus limiting the related product development and know-how transfer associated } \\
\text { with working with an international life reinsurer. } \\
\text { All insurers and reinsurance brokers intending to reinsure/place any risks abroad are required } \\
\text { to apply to NAICOM for in-principle approval. } \\
\text { During onsite inspections, inspectors verify the accuracy and validity of reinsurance } \\
\text { arrangements. } \\
\text { Existing legislation is silent on whether risk transfer to capital markets is permitted. } \\
\text { - }\end{array}$ \\
\hline
\end{tabular}




\begin{tabular}{|c|c|}
\hline Assessment & Partly observed \\
\hline Comments & $\begin{array}{l}\text { While NAICOM has issued guidelines on the Board's and senior management's respective } \\
\text { responsibilities in setting reinsurance policy, the appropriateness of the reinsurance protection } \\
\text { is required. The determination of the reinsurance programs should consider effective risk } \\
\text { transfer and protection of the solvency of the insurer. Mandatory cessions and the exclusive } \\
\text { use of local reinsurance should be waived by NAICOM if contravening the board's reinsurance } \\
\text { policy. } \\
\text { It is advised that NAICOM should expand the scope of the reinsurance component of onsite } \\
\text { inspection programs to take into account the reinsurance guidelines, and include consideration } \\
\text { of liquidity and reinsurers' payment patterns. } \\
\text { Reinsurance programs should only be allowed that pass a risk transfer test and to enhance } \\
\text { transparency side letters should be forbidden by requiring the entire contract clause in each } \\
\text { treaty. }\end{array}$ \\
\hline ICP 14 & $\begin{array}{l}\text { Valuation } \\
\text { The supervisor establishes requirements for the valuation of assets and liabilities for solvency } \\
\text { purposes. }\end{array}$ \\
\hline Description & $\begin{array}{l}\text { Effective January } 1,2012 \text { as indicated in the } 2011 \text { Operational Guideline for insurers and } \\
\text { reinsurers, Nigeria has adopted IFRS for the reporting of the financial statements following the } \\
\text { recommendation of the FRC. All insurance and reinsurance companies had to submit their } \\
\text { plans for IFRS conversion by April } 2011 \text {, dual accounts have been presented for the reporting } \\
\text { year } 2011 \text { and the first quarter reports are using IFRS as the new standard. The regulations } \\
\text { are being updated to prescribe IFRS as the accounting standard to be used for audited } \\
\text { financial statements and for regulatory reporting. } \\
\text { For solvency purposes regulation provides for the valuation of assets. It defines classes and } \\
\text { limits for admissible assets and mandates IFRS for their valuation. It includes amortized, lower } \\
\text { of cost or net realized value for unquoted stocks and short term investments, and market } \\
\text { valuations for quoted securities. } \\
\text { Section } 24 \text { of IA defines admissible assets to be those invested in: } \\
\text { a) cash and bank balance; } \\
\text { b) quoted investment at market value; } \\
\text { c) unquoted stock at cost; } \\
\text { d) land and buildings; } \\
\text { e) furniture and fittings; } \\
\text { f) office equipment; } \\
\text { g) motor vehicles; } \\
\text { h) prepaid expenses made to member of staff; } \\
\text { i) amount due from retrocession; } \\
\text { j) staff loans and advances; and } \\
\text { k) claims receivable. } \\
\text { - Inverational Guidelines } 1.6 \text { stipulates that admissible assets for solvency purposes include: } \\
\text { - Deferred acquisition cost; } \\
\text { - Prepaid reinsurance cost, } \\
\text { but exclude: } \\
\text { - Revaluation surplus of assets/investment properties that have not stayed in the books for }\end{array}$ \\
\hline
\end{tabular}




\begin{tabular}{|c|c|}
\hline & 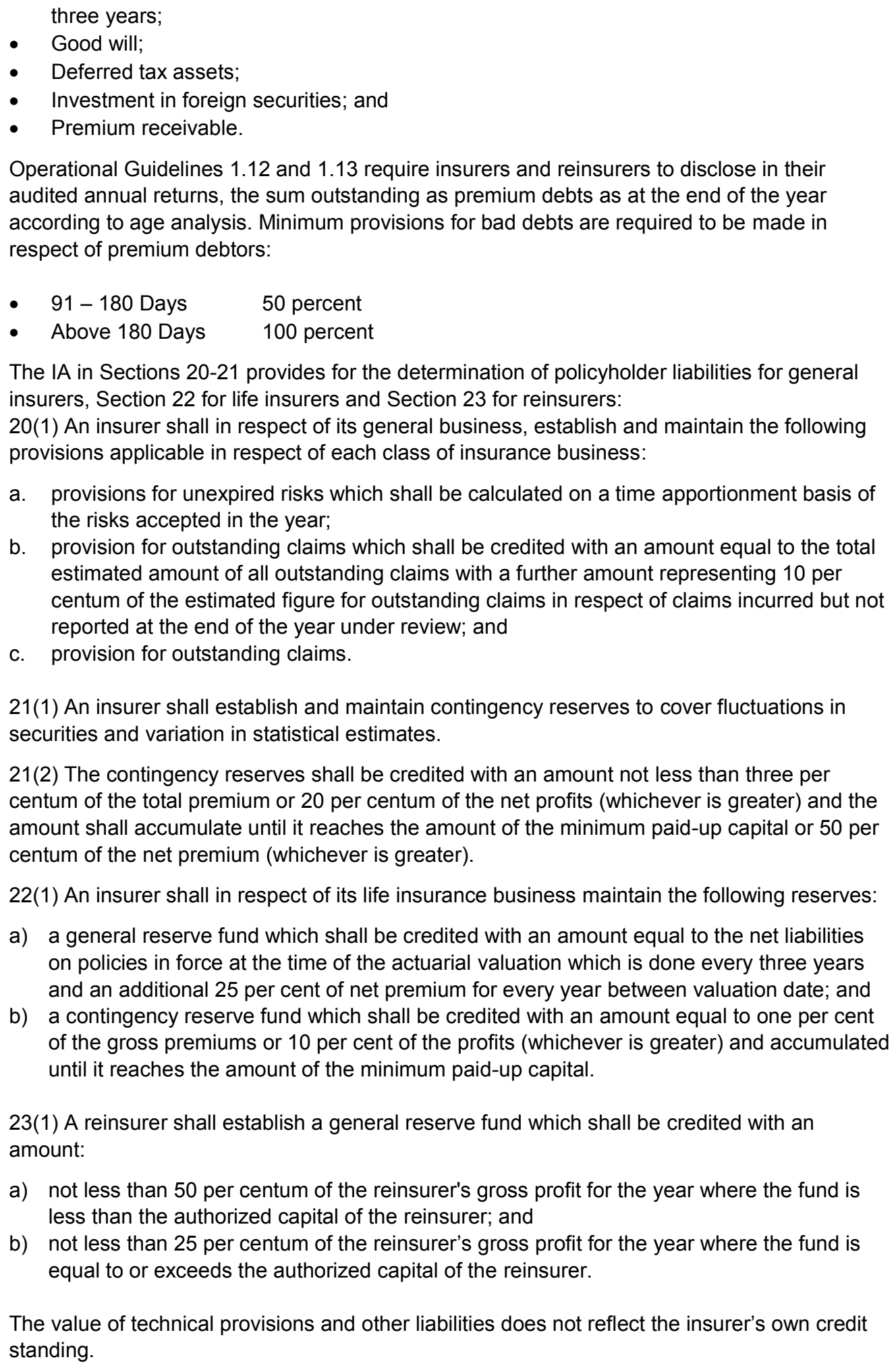 \\
\hline Assessment & Partly observed \\
\hline Comments & The introduction of IFRS standard for reporting is welcomed. The market-consistent valuation \\
\hline
\end{tabular}


of assets and enhanced disclosure will improve transparency of the industry. However, full implementation of IFRS will require a few years until it is understood and properly applied. During this transition period NAICOM is recommended to remain vigilant to avoid misuses or errors in the valuations and application of IFRS.

The definition of admissible assets for solvency purposes together with the concentration and class limits appear to be sufficient for the existing investment environment and insurance products. Also, reinsurance recoverable should call for provisioning beyond a reasonable aging period.

The valuation of liabilities is weak and needs to be overhauled:

1. For non-life business, Section 20 of IA requires insurers to maintain provisions for unexpired risks, and outstanding claims with 10 percent margin for IBNR. Section 21 of IA requires insurers to maintain a contingency reserve to cover fluctuations in investments and underwriting experience.

- There are no requirements for an actuarial valuation of the sufficiency of the reserves, nor the appropriateness of the IBNR calculation or adjustments according to the experience observed.

2. For life business, Section 22 of IA requires insurers to maintain a general reserve equal to net liabilities of policies in-force determined by an actuary. The actuarial valuation is done every three years and an additional 25 percent of net premium for every year between valuations is added to the reserve. In addition, a contingency reserve is required that is equal to 1 percent of the gross premiums or 10 percent of the profits (whichever is greater) and accumulated until it reaches the amount of the minimum paid-up capital.

- The actuarial valuation needs to be on an annual basis and the actuarial standards specified in regulation either explicitly or with a reference to existing international actuarial standards.

3. For reinsurers' business, Section 23 of IA requires reinsurers to maintain a general reserve fund which is credited with (a) not less than 50 percent of its gross profit for the year where the fund is less than the authorized capital; and (b) not less than 25 percent of its gross profit for the year where the fund is equal to or exceeds the authorized capital.

- The prescribed reserves have no relationship with the assumed liabilities and an actuarial valuation of the sufficiency of the reserves, like in the case of non-life insurers, is recommended.

The contingency reserve requirement introduces a prudent element into the liabilities calculation but its use needs to be specified and allowed for those specified situations like the statistical deviation of claims or the occurrence of extreme events, otherwise the contingency reserve will only be of value in extreme situations of insolvency.

There are six actuaries in Nigeria, one of whom is no longer working in the profession. Of the remaining five, four are working with three companies, leaving only one consulting actuary to meet the needs of the industry. NAICOM could consider using the Education Fund to develop university programs to groom future actuarial professionals.

\section{\begin{tabular}{l|l} 
ICP 15 & Investment
\end{tabular}}

The supervisor establishes requirements for solvency purposes on the investment activities of insurers in order to address the risks faced by insurers.

Description

Operational Guidelines 1.10 require insurers and reinsurers to have investment policies duly approved by the board. All investment decisions shall be guided by the board-approved investment policy, and the basis for investment selection shall be properly documented for independent review. Such policies should recognize the nature and differences between funds available to the insurers/ reinsurers and all investments relating to insurance funds need to be 


\begin{tabular}{|c|c|}
\hline & $\begin{array}{l}\text { distinguished from those representing other funds in the financial statements. } \\
\text { Recognized assets for solvency purposes are defined as admissible assets (also see ICP 14) } \\
\text { and subject to certain limits. } \\
\text { Concentration limits: } \\
\text { - Not more than } 20 \text { percent of the total current accounts balances and bank placements } \\
\text { shall be placed in any one bank. } \\
\text { - Not more than } 20 \text { percent of the total equity investment shall be placed in the security of } \\
\text { one company. } \\
\text { - No insurer/ reinsurer shall invest more than } 25 \text { percent of the proceeds of public offers } \\
\text { and private placements of shares in non-insurance related companies or ventures. } \\
\text { Subject to the liquidity required for relevant obligations of the insurers/reinsurers, the } \\
\text { following limits should be observed with regards to investment-type decisions on } \\
\text { insurance funds. } \\
\text { a) Quoted equity, not more } 50 \text { percent } \\
\text { b) Unquoted equity, not more than } 10 \text { percent } \\
\text { c) Equipment leasing, not more than } 5 \text { percent } \\
\text { d) Property, not more than } 35 \text { percent in the case of life insurance funds, and } 25 \text { percent } \\
\text { in the case of non-life insurance funds. } \\
\text { Investments in unprofitable companies are forbidden by regulation: } \\
\text { - No insurer/reinsurer shall invest in its parent company. } \\
\text { Insurance funds shall not be invested in any subsidiary. } \\
\text { Investment of shareholders' funds in associates, subsidiaries and related companies } \\
\text { should be limited to } 25 \text { percent of such funds. } \\
\text { No insurer/reinsurer shall invest in any company that either has not reported profits or paid } \\
\text { dividends in the preceding three years. }\end{array}$ \\
\hline Assessment & Partly observed \\
\hline Comments & $\begin{array}{l}\text { NAICOM is open and transparent as to the regulatory investment requirements that apply. The } \\
\text { requirements are set in the IA and in the Operational Guidelines. They address to a certain } \\
\text { extent security, liquidity and diversification through limits by issuer, by deposits held in a single } \\
\text { bank, and by the classes of investments, with lower limits for riskier assets. However, there } \\
\text { are no explicit requirements on the credit standing, level of liquidity or asset liability matching } \\
\text { for the selection of investments. } \\
\text { Going forward NAICOM should consider introducing a well-defined overarching prudent man } \\
\text { type of concept to guide the investments of insurers. This will cover all risks, like credit, } \\
\text { concentration, liquidity, etc., without leaving a regulatory gap and without being too } \\
\text { prescriptive. In the initial stage of introduction, close monitoring and detailed guidance on what } \\
\text { is expected from the investment policy is recommended. } \\
\text { While IFRS and the risk management requirements will to a certain extent encourage the } \\
\text { proper understanding and valuation of all investments, there is no explicit requirement on the } \\
\text { use of more complex and less transparent classes of investments or investment in markets or } \\
\text { instruments that are subject to less governance or regulation. The introduction of explicit } \\
\text { requirements on the use of these more complex and less transparent classes of investments is } \\
\text { recommended to accompany the market development toward the use of more complex } \\
\text { investments. Given the current level of investment expertise in the industry, prohibition of the }\end{array}$ \\
\hline
\end{tabular}




\begin{tabular}{|c|c|}
\hline & $\begin{array}{l}\text { use of derivatives is also recommended. } \\
\text { There is some level of segregation of the policyholder funds. Regulation states that all } \\
\text { investments relating to insurance funds need to be earmarked. However, there are no } \\
\text { requirements to have those assets in trust or with a custodian. It is recommended to require } \\
\text { that policyholders' assets related to investment products are segregated in independent trusts. }\end{array}$ \\
\hline ICP 16 & $\begin{array}{l}\text { Enterprise Risk Management for Solvency Purposes } \\
\text { The supervisor establishes enterprise risk management requirements for solvency purposes } \\
\text { that require insurers to address all relevant and material risks. }\end{array}$ \\
\hline Description & $\begin{array}{l}\text { The RM Guidelines that took effect on July } 1,2012 \text { require the insurers and reinsurers to } \\
\text { establish risk management policies and processes for dealing with material risks, including } \\
\text { identification, assessment, control, monitoring, and reporting on an enterprise-wide basis, as } \\
\text { well as having disaster recovery/business continuity management. The RM Guidelines require } \\
\text { the establishment of a board-level ERM Committee to be responsible for the insurer's ERM } \\
\text { process. } \\
\text { The Guidelines identify and describe the following material risks: } \\
\text { a) market risk/Investment risk; } \\
\text { b) credit risk; } \\
\text { c) operational risk; } \\
\text { d) liquidity risk; } \\
\text { e) reinsurance risk; } \\
\text { f) underwriting risk; } \\
\text { g) provisioning/reserving risk; } \\
\text { h) claims management risk; } \\
\text { i) business risk; } \\
\text { j) reputational risk; } \\
\text { k) legal/litigation risk; and } \\
\text { I) such other risks to which the company may be exposed. } \\
\text { Guidelines require insurers to review the effectiveness and comprehensiveness of their risk } \\
\text { management framework by "operationally independent, appropriately trained and competent } \\
\text { persons." Internal audit is an acceptable unit to perform the review. The frequency and scope } \\
\text { of the review should be appropriate to the company, having regards to such factors as the } \\
\text { size, business mix, and complexity of the company's operations and the extent of any change } \\
\text { to its business profile or its risk appetite. The required review stops short of assessing the } \\
\text { insurer's solvency position. } \\
\text { NAICOM has conducted a workshop for CEOs of insurers in March } 2012 \text { to explain the } \\
\text { concepts and requirements of the RM Guidelines. } \\
\text { RM Guidelines require the board of directors to submit an annual risk management declaration } \\
\text { to certify that the insurer has complied with the RM Guidelines and that the board is satisfied } \\
\text { with the efficacy of the process of producing financial information. } \\
\text { Recognizing that the ERM framework is still evolving in Nigeria, NAICOM has set up a cross- } \\
\text { departmental risk management committee to review the risk management framework adopted } \\
\text { by each insurer, to ascertain compliance with the RM Guidelines, as well as to discern industry } \\
\text { best practices. }\end{array}$ \\
\hline Assessment & Partly observed \\
\hline Comments & $\begin{array}{l}\text { The ERM framework has just been implemented two months ago. Each insurer has submitted } \\
\text { its RM framework to NAICOM. The effectiveness of the framework is yet to be seen. } \\
\text { There are a few key elements that NAICOM should include in the RM Guidelines, e.g.,stress }\end{array}$ \\
\hline
\end{tabular}




\begin{tabular}{|c|c|}
\hline & $\begin{array}{l}\text { testing as a tool to assess risk, asset-liability management, and insurer's own assessment of } \\
\text { solvency. }\end{array}$ \\
\hline ICP 17 & $\begin{array}{l}\text { Capital Adequacy } \\
\text { The supervisor establishes capital adequacy requirements for solvency purposes so that } \\
\text { insurers can absorb significant unforeseen losses and to provide for degrees of supervisory } \\
\text { intervention. }\end{array}$ \\
\hline Description & 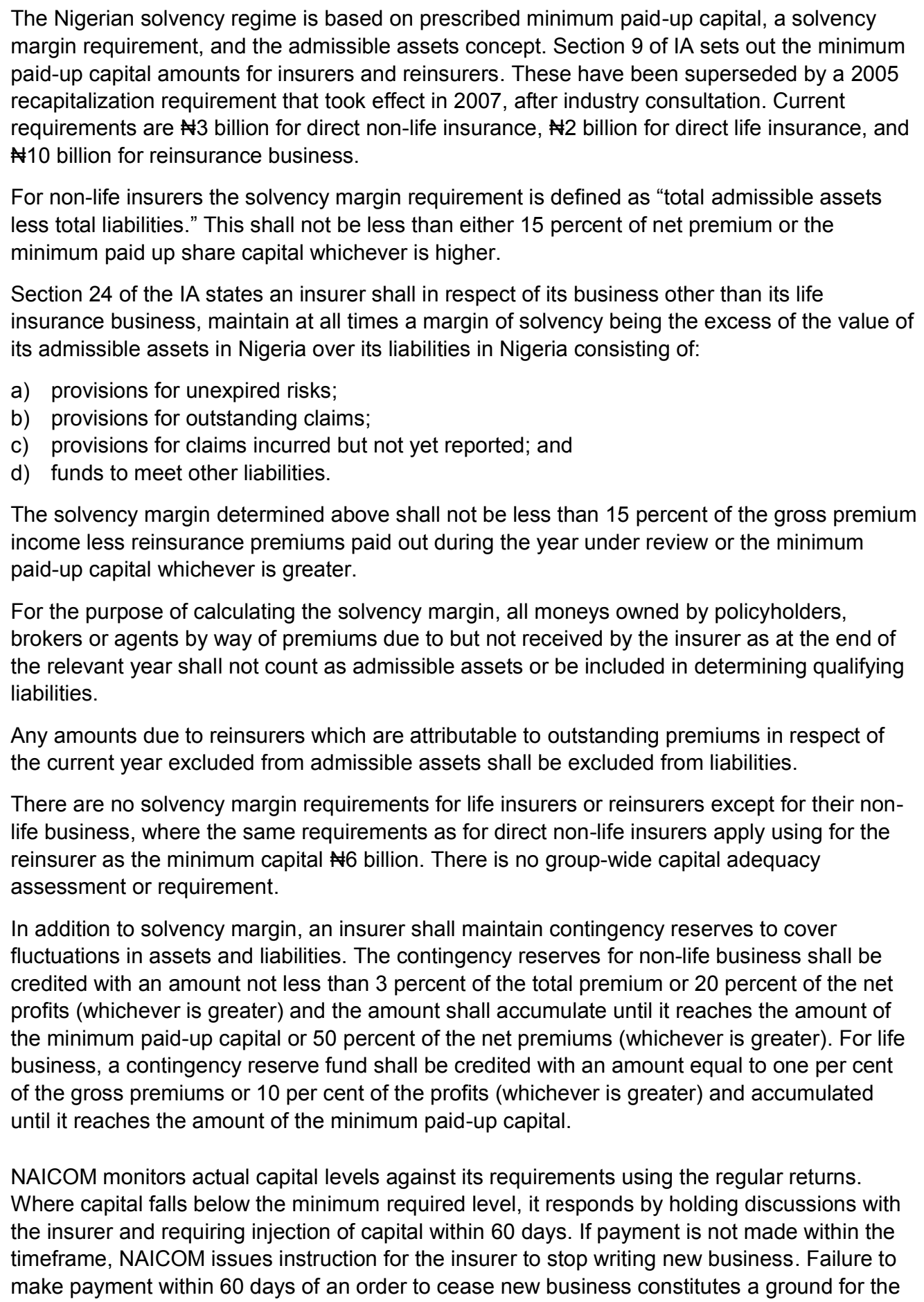 \\
\hline
\end{tabular}

CInternational Monetary Fund. Not for Redistribution 


\begin{tabular}{|c|c|}
\hline & $\begin{array}{l}\text { cancellation of license of an insurer under Section } 8 \text { of IA. A wilful disregard of the order to } \\
\text { cease new business is also ground for cancellation of license. } \\
\text { There are no other solvency control levels that trigger different degrees of supervisory } \\
\text { intervention. }\end{array}$ \\
\hline Assessment & Partly observed \\
\hline Comments & $\begin{array}{l}\text { The existing solvency regime is not useful to effectively supervise and monitor the resilience of } \\
\text { insurers. There is urgent need for enhancements. } \\
\text { The current solvency regime uses a percentage of premium as the solvency margin for non- } \\
\text { life insurers. For life insurers the solvency requirement is based on full reliance on an actuarial } \\
\text { sufficiency valuation. Reinsurers are excluded from solvency requirements except for their } \\
\text { non-life business, which is similar to the direct non-life insurers. There is some conservatism in } \\
\text { the introduction of contingency reserves and limitation on the dividend distribution but the } \\
\text { current solvency regime does not address the risks assumed by the insurers. } \\
\text { NAICOM is aware of the drawbacks of such a simplistic solvency regime and as part of its } \\
\text { strategic plan to move toward risk-based supervision, NAICOM intends to move towards a } \\
\text { regime of risk-based capital. It is recommended to treat this initiative with highest priority. } \\
\text { NAICOM should review the appropriateness of the existing minimum paid-up capital under the } \\
\text { pending risk-based capital regime. }\end{array}$ \\
\hline ICP 18 & $\begin{array}{l}\text { Intermediaries } \\
\text { The supervisor sets and enforces requirements for the conduct of insurance intermediaries, to } \\
\text { ensure that they conduct business in a professional and transparent manner. }\end{array}$ \\
\hline Description & $\begin{array}{l}\text { Insurance agents, brokers and loss adjusters are required to be licensed in Nigeria, } \\
\text { renewable annually. They are subject to on-site (except agents) and off-site supervision. } \\
\text { Licensing of Agents } \\
\text { Insurance agents must be natural persons. They may have more than one principal. To } \\
\text { qualify for the license, agents must possess certificates of proficiency issued by the CIIN and } \\
\text { have not been convicted by a court or tribunal of an offence in the nature of criminal } \\
\text { misappropriation of funds or breach of trust or cheating. } \\
\text { Unlicensed persons transacting business as insurance agents are liable for a fine of } \\
\text { agents are liable for a fine of } 100,000 \\
\text { agents ar both. Insurers doing business with unlicensed } \\
\text { An insurer must maintain a register showing the name, address, date of appointment and } \\
\text { date of termination of every insurance agent it has appointed. } \\
\text { Licensing of Brokers } \\
\text { An insurance broker may be a partnership or a limited liability company. Brokers must be } \\
\text { members of the Nigerian Council of Registered Insurance Brokers. Partners, CEO and } \\
\text { executive directors of a broking firm must be members of CIIN. The license may be cancelled } \\
\text { if the broker: } \\
\text { a) has knowingly or recklessly contravened the IA; } \\
\text { b) practises as a loss adjuster; } \\
\text { c) has, for the purpose of obtaining a license or paying a levy to NAICOM, made a } \\
\text { statement which is false in any material particular; } \\
\text { d) has been found guilty of fraudulent or dishonest practice (including misappropriation of } \\
\text { clients' money); } \\
\text { e) has acted contrary to the Code of Conduct of the profession; or } \\
\text { f) has failed to pass on premiums to insurers (Section } 41 \text { (4)). }\end{array}$ \\
\hline
\end{tabular}


Before the license application is approved, the pending approval is published in national newspapers to solicit public comment. After the 21-day public comment period, NAICOM conducts a face-to-face interview with the brokers before the license is issued.

Unlicensed persons transacting business as insurance brokers are liable for a fine of \#250,000 and/or two years of imprisonment in the case of non-corporates. Insurers doing business with unlicensed brokers are liable for a fine of $\$ 250,000$.

There is no paid-up capital requirement for brokers. However, a broking firm must maintain professional indemnity cover of not less than $\$ 10$ million, or 50 percent of its annual brokerage income for the preceding year, whichever is the greater.

\section{Licensing of Loss Adjusters}

A loss adjuster may be a partnership or a limited liability company. At least one partner or director, and the CEO of a loss-adjusting firm must be a member of the Institute of Loss Adjusters of Nigeria. The license may be cancelled if the loss adjuster:

a) has knowingly or recklessly contravened the IA;

b) has, for the purpose of obtaining a license or paying a levy to NAICOM, made a statement which is false in any material particular;

c) has been found guilty of fraudulent or dishonest practice (including misappropriation of clients' money); and

d) has acted contrary to the Code of Conduct of the profession.

Similar to the requirements for brokers, granting of a loss adjuster's license is subject to a 21day public comment period and an interview with NAICOM.

Unlicensed loss adjusters are liable for a fine of $\$ 250,000$. Insurers doing business with unlicensed loss adjusters are liable for a fine of $\$ 100,000$.

There is no paid-up capital requirement for loss adjusters. However, a loss adjuster must maintain professional indemnity cover of not less than $\$ 5$ million, or 50 percent of its annual income for the preceding year, whichever is the greater.

NAICOM has taken action against intermediaries who operate without a license.

\section{Off-site Monitoring: Filing of Returns and Accounts}

a) Insurance brokers: Audited statement of accounts within six months after the accounting year (calendar year).

b) Loss adjusters: Audited statement of accounts within six months after the accounting year (calendar year).

c) Agents: All insurance agents must file an annual statement of transactions at the time of renewal of license. The statement should comprise premium incomes and commissions, attested to by the CEO of the appointing insurer.

Half yearly, insurance brokers must file a Statement of Business and loss adjusters must file a Statements of Claims Adjusted, within 30 days.

All broking and loss-adjusting firms must file the personnel status as at the end of each year. Every staff member, including Executive Directors, must be a full time employee.

Late filing of returns is liable for a fine of $\$ 5,000$ per day.

On-Site Inspection

NAICOM selectively conducts onsite inspections of insurance brokers only.

Handling of Clients' Money

An insurance agent is required to immediately pay to the insurer any premium collected by him. Failure to do so will result in a fine of $\$ 10,000$ and/or six months imprisonment for the first offence; $\$ 50,000$ and/or one year imprisonment for the second offence; 100,000 , three 


\begin{tabular}{|c|c|}
\hline & $\begin{array}{l}\text { years imprisonment, and cancellation of license for the third offence. } \\
\text { A broker is required to separate clients' funds from its own funds. All monies, premiums, } \\
\text { claims and recoveries from and on behalf of clients, insurers and reinsurers are paid into } \\
\text { "clients' bank accounts" established by the brokers. Failing to do so, a broker is liable for a fine } \\
\text { of } 250,000 \text { and/or three years imprisonment. } \\
\text { All clients' bank account names must be pre-fixed by "Clients' Account of..." Moreover, every } \\
\text { mandate for clients' bank accounts should specify that the account is a clients' account and } \\
\text { therefore subject to the requirements of IA and relevant regulations and guidelines. It should } \\
\text { also state that the funds in the account can neither be used as collateral for any loan facility } \\
\text { nor offset against any liability. } \\
\text { All brokers are required to ask their bankers to forward to NAICOM a certificate of compliance } \\
\text { with the clients' bank accounts requirements, which should contain: } \\
\text { - account name, } \\
\text { - account number, } \\
\text { - account type (current or term deposits), and } \\
\text { - mandate for operations of the account(s). } \\
\text { All brokers shall on a quarterly basis file with NAICOM statements in respect of operation of } \\
\text { the clients' bank accounts. }\end{array}$ \\
\hline Assessment & Partly observed \\
\hline Comments & $\begin{array}{l}\text { NAICOM has rigorous licensing requirements for intermediaries. Licenses are annually } \\
\text { renewable. NAICOM relies on insurers to control their agents. Ongoing supervision of brokers } \\
\text { and loss adjusters is limited in scope. } \\
\text { The requirements on proper handling of clients' money are comprehensive and adequate. } \\
\text { However, a great amount of premium receivables still exists in the balance sheets of insurers. } \\
\text { NAICOM needs to increase its efforts to reduce the amount of outstanding premiums that } \\
\text { remains with the brokers. One possible way to address the issue is to require premium } \\
\text { payments to be exclusively done through bank accounts. } \\
\text { There are basically no disclosure requirements for brokers when dealing with prospects and } \\
\text { customers. Insurance intermediaries should be required to disclose their capacity as agents or } \\
\text { brokers, how they are paid, range of products, potential conflict of interest when the } \\
\text { intermediary is part of an insurance group, etc. }\end{array}$ \\
\hline ICP 19 & $\begin{array}{l}\text { Conduct of Business } \\
\text { The supervisor sets requirements for the conduct of the business of insurance to ensure } \\
\text { customers are treated fairly, both before a contract is entered into and through to the point at } \\
\text { which all obligations under a contract have been satisfied. }\end{array}$ \\
\hline Description & $\begin{array}{l}\text { Conduct of business requirements are scattered in various provisions in IA and reflected in } \\
\text { NAICOM's product approval process. The relevant provisions in IA include: } \\
\text { - Proposal form should contain request for material facts. } \\
\text { - Premiums collected by a broker are deemed to be received by the insurer. } \\
\text { - Caps on commissions, and prohibition of rebates. } \\
\text { - Payment of uncontested claims within } 90 \text { days. If unpaid after } 90 \text { days, the claimant may } \\
\text { - } \quad \text { If the insurer contests the claim, it must inform the claimant in writing the reason for } \\
\text { disclaiming the liability within } 90 \text { days. } \\
\text { NAICOM approves all new insurance products. The approval extends to the proposal form, } \\
\text { marketing materials, policy documents, and premium rates and their basis. NAICOM also aims }\end{array}$ \\
\hline
\end{tabular}




\begin{tabular}{|c|c|}
\hline & $\begin{array}{l}\text { to ensure that products are not too complex and outside the core business of the insurer. } \\
\text { Operational Guidelines require insurers to disclose in the audited annual accounts all } \\
\text { contraventions on which penalties have been imposed. NAICOM publishes certain regulatory } \\
\text { actions taken against insurers such as suspension, but not composition fines. These } \\
\text { disclosures serve to alert the public of market misconduct by insurers. } \\
\text { NAICOM has in place a Complaints Bureau, which settles insurance disputes. The Complaints } \\
\text { Bureau is a unit of NAICOM, established in accordance with Section } 8(a) \text { of the NA, and } \\
\text { manned by NAICOM staff. Decisions of the Bureau are not binding. Either party may further } \\
\text { pursue the matter in the court of law. The unit handled } 300 \text { to } 500 \text { cases each year } \\
\text { during } 2007-2010 \text {, covering an estimated value of claims in the region of } 22 \text { billion each year. } \\
\text { Both participating and non-participating life insurance policies are sold in Nigeria. However, } \\
\text { there are no provisions in the regulations to cater to the unique nature of participating policies. } \\
\text { There is no legislation regarding protection of customers' private information. } \\
\text { NAICOM runs a TV program every Saturday morning called "Insurance \& Claims" which } \\
\text { provides information on customers' rights and guidance on how to deal with insurance claims } \\
\text { issues. The program has been running for more than two years. }\end{array}$ \\
\hline Assessment & Partly observed \\
\hline Comments & $\begin{array}{l}\text { The analysis that NAICOM conducts in approving products is superficial. Premium rates are } \\
\text { approved without challenge. In substance, product approval does not appear to be an effective } \\
\text { tool to achieve fair treatment of customers. } \\
\text { The relevant market conduct requirements in the IA are scattered and not sufficiently } \\
\text { comprehensive. NAICOM is advised to issue market conduct regulations incorporating the } \\
\text { principles of treating customers fairly in each stage of insurance business: product design, } \\
\text { marketing, fact-finding, giving advice, underwriting, policy service and claim. } \\
\text { NAICOM should require segregation of insurance funds for participating and non-participating } \\
\text { business to facilitate the proper determination of experience sharing. There should be } \\
\text { requirements on the profit sharing between participating policyholders and shareholders. } \\
\text { Actuaries should be required to certify that the allocation of bonuses to participating policies } \\
\text { meets regulatory requirements and policyholders' reasonable expectations. } \\
\text { NAICOM should also address the advisory and disclosure standard for participating products, } \\
\text { with emphasis on distinguishing guaranteed versus non-guaranteed elements of the policy. } \\
\text { Customer complaints are an indicator of weakness in operation or internal controls. NAICOM } \\
\text { should require insurers to have in place complaints handling procedures and examine how } \\
\text { insurers handle complaints during on-site inspections. }\end{array}$ \\
\hline ICP 20 & $\begin{array}{l}\text { Public Disclosure } \\
\text { The supervisor requires insurers to disclose relevant, comprehensive and adequate } \\
\text { information on a timely basis in order to give policyholders and market participants a clear } \\
\text { view of their business activities, performance and financial position. This is expected to } \\
\text { enhance market discipline and understanding of the risks to which an insurer is exposed and } \\
\text { the manner in which those risks are managed. }\end{array}$ \\
\hline Description & $\begin{array}{l}\text { The IA requires an insurer, after receiving approval from NAICOM, to publish its full-year } \\
\text { financial statements (balance sheet and profit and loss account) in at least one newspaper } \\
\text { having wide circulation in Nigeria. Annual reports are filed with the Companies Registrar and } \\
\text { submitted to NAICOM. The public may access the annual reports online through the } \\
\text { Companies Registrar at a fee. Alternatively, the public may view the annual reports in person } \\
\text { at the Registrar or at the NAICOM office. }\end{array}$ \\
\hline
\end{tabular}




\begin{tabular}{|c|c|}
\hline & $\begin{array}{l}\text { The submission deadline of the annual audited financial statements is } 6 \text { months after the close } \\
\text { of the financial year. NAICOM spends an inordinate amount of time in verifying the accuracy of } \\
\text { the financial information. Consequently, the publication of the financial statements could be } \\
\text { long after the end of the year. } \\
\text { Currently, there are no specific requirements for the insurer to disclose corporate objectives } \\
\text { and strategies, risks and their management, investment policy, capital adequacy, etc. The } \\
\text { CGCG has a provision that the annual report should "confirm an internal audit report which will } \\
\text { state the responsibility of management for establishing and maintaining an adequate internal } \\
\text { control structure and procedure of the issuer for financial reporting." But compliance with } \\
\text { CGCG is not compulsory. }\end{array}$ \\
\hline Assessment & Partly observed \\
\hline Comments & $\begin{array}{l}\text { Approved annual financial statements are published in newspaper. Annual reports are } \\
\text { available to the public from the Companies Registrar and the NAICOM. However, there are no } \\
\text { requirements on the content of the annual report. Consequently, policyholders and market } \\
\text { participants in most if not all cases do not have access to relevant information, such as the } \\
\text { insurer's strategies, risks, financial condition, and performance. The situation is likely to } \\
\text { improve with the adoption of IFRS from 2012. NAICOM should monitor the quality of } \\
\text { disclosures made by insurers and issue guidelines and/or guidance notes in the future if } \\
\text { appropriate. } \\
\text { The current timeline of releasing financial statements is too long. NAICOM should shorten the } \\
\text { timeline to ensure more timely dissemination of information. The possibility of a reduction to } \\
\text { three months from the current } 6 \text { months for the submission of the annual statements should be } \\
\text { considered, in conjunction with efforts to strengthen the quality of audits. }\end{array}$ \\
\hline ICP 21 & $\begin{array}{l}\text { Countering Fraud in Insurance } \\
\text { The supervisor requires that insurers and intermediaries take effective measures to deter, } \\
\text { prevent, detect, report and remedy fraud in insurance. }\end{array}$ \\
\hline Description & $\begin{array}{l}\text { Insurance frauds are criminal offences under the general criminal law. While NAICOM does } \\
\text { not have the legal authority to investigate insurance frauds, it may report frauds to the relevant } \\
\text { authorities and cooperate with other local and foreign authorities. } \\
\text { In July 2012, the industry in collaboration with other stakeholders launched a motor insurance } \\
\text { verification database to stamp out fake insurance certificates. NAICOM estimates that over } \\
70 \text { percent of vehicles on the roads are in possession of fake motor insurance certificates. Law } \\
\text { enforcement officers have often found it difficult to differentiate between the genuine and the } \\
\text { fake certificates. With the database, law enforcement officers and vehicle owners can verify } \\
\text { the authenticity of motor insurance certificates easily and quickly. All they need to do is send } \\
\text { an SMS of the policy number and the vehicle plate number, and will receive a reply within a } \\
\text { minute. Alternatively, they can check online. } \\
\text { Operational Guidelines require all insurers and reinsurers to file quarterly fraud reports with } \\
\text { NAICOM, containing the following information: } \\
\text { - Identity of perpetrator } \\
\text { - Nature of malpractice } \\
\text { - Amount involved } \\
\text { - Penalty } \\
\text { Preventive measures } \\
\text { vulCOM does not analyze the fraud reports filed. Nor does it analyze overall market }\end{array}$ \\
\hline
\end{tabular}




\begin{tabular}{|c|c|}
\hline Assessment & Partly observed \\
\hline Comments & $\begin{array}{l}\text { NAICOM does not explicitly require insurers to have in place procedures to deter, detect, } \\
\text { prevent and remedy frauds. Nonetheless, the requirement to file quarterly fraud reports is } \\
\text { likely to raise awareness of frauds and anti-fraud measures. } \\
\text { NAICOM is advised to make use of the information reported to understand the types of fraud } \\
\text { risks, to analyze overall market vulnerability, to assess the effectiveness of each insurer's } \\
\text { fraud prevention measures, and to improve the overall effectiveness through shared } \\
\text { experience, such as the motor insurance verification database. }\end{array}$ \\
\hline ICP 22 & $\begin{array}{l}\text { Anti-Money Laundering and Combating the Financing of Terrorism } \\
\text { The supervisor requires insurers and intermediaries to take effective measures to combat } \\
\text { money laundering and the financing of terrorism. In addition, and the supervisor takes effective } \\
\text { measures to combat money laundering financing of terrorism. }\end{array}$ \\
\hline Description & 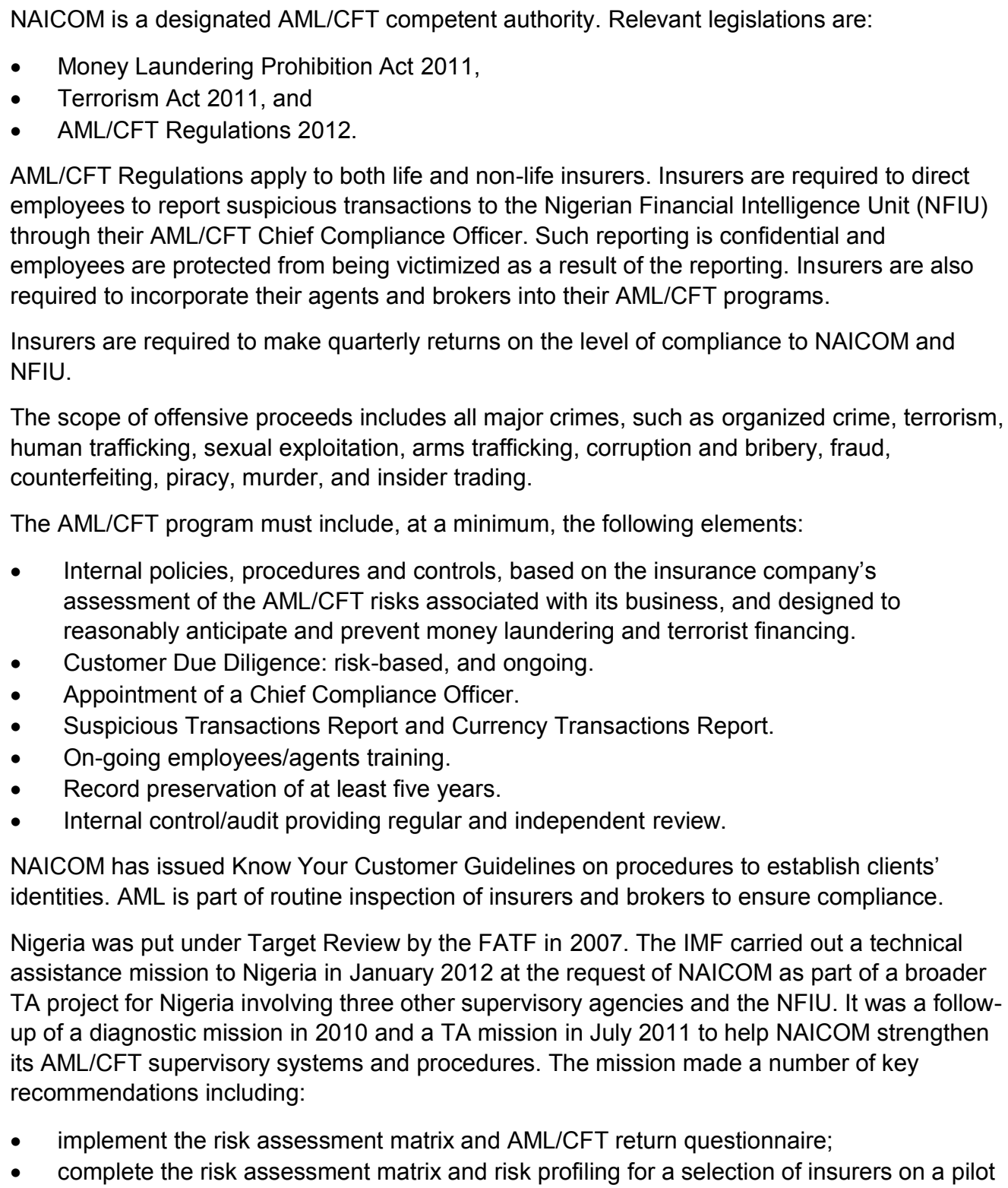 \\
\hline
\end{tabular}




\begin{tabular}{|c|c|}
\hline & $\begin{array}{l}\text { basis; and } \\
\text { review the draft supervision manual and conduct workshops with insurers. } \\
\text { NAICOM issued revised AML Regulations in } 2012 \text { and has held an industry workshop to cover } \\
\text { points raised by the IMF. } \\
\text { NAICOM has organized an AML/CFT workshop for compliance officers and heads of internal } \\
\text { audit to improve AML/CFT awareness among insurers. The workshop was jointly conducted } \\
\text { by NAICOM, NFIU and consultants. } \\
\text { AML/CFT compliance is part of the routine inspection program. Among other things, inspectors } \\
\text { check for KYC procedures, reporting of suspicious transactions, large and suspicious claims, } \\
\text { and handling of politically exposed persons. NAICOM has conducted joint inspections on AML } \\
\text { with other relevant national authorities. }\end{array}$ \\
\hline Assessment & Largely observed \\
\hline Comments & $\begin{array}{l}\text { NAICOM has put in effort to implement an effective AML/CFT regime for the insurance sector. } \\
\text { It has promulgated regulations to clearly set out the insurers' AML/CFT responsibilities. A } \\
\text { "largely observed" rating is given for the sole reason that the regime is too new for its } \\
\text { effectiveness to be observed. } \\
\text { While the majority of the insurance business is non-life and the life business is group life, } \\
\text { neither of which are prone to AML/CFT abuses, the large minimum capital requirements } \\
\text { relative to the business volume could be a source of vulnerability. NAICOM is recommended } \\
\text { to critically analyse the strategy and business plans of insurers that are not producing } \\
\text { significant business in relation to their capital. }\end{array}$ \\
\hline ICP 23 & $\begin{array}{l}\text { Group-wide Supervision } \\
\text { The supervisor supervises insurers on a legal entity and group-wide basis. }\end{array}$ \\
\hline Description & $\begin{array}{l}\text { The insurance legislation does not define what constitutes an insurance group and a financial } \\
\text { conglomerate. NAICOM's supervisory power is on insurance entities it licenses. NAICOM does } \\
\text { not have the explicit authority to supervise or request information from non-regulated entities } \\
\text { within an insurance group. } \\
\text { Currently, there are two financial conglomerates in Nigeria, involving insurance and securities } \\
\text { operations. There are } 9 \text { insurance companies that have insurance subsidiaries in other African } \\
\text { countries. The majority of these foreign subsidiaries are located in Ghana. There is one insurer } \\
\text { owning a pension operation. } \\
\text { Through FSRCC, NAICOM is able to obtain supervisory information from other national } \\
\text { regulators. NAICOM may also request information from foreign regulators through its MOU } \\
\text { with Ghana, and other informal channels. However, all prudential and market conduct } \\
\text { requirements are applicable only to the licensed entity. }\end{array}$ \\
\hline Assessment & Not observed \\
\hline Comments & $\begin{array}{l}\text { NAICOM is advised to amend primary legislation to develop and be granted explicit power to } \\
\text { conduct group-wide supervision, including the supervision of the holding company. This will be } \\
\text { of more importance with the introduction of holding companies by banks wanting to retain } \\
\text { interests in insurers. } \\
\text { NAICOM should require insurance group structure to be sufficiently transparent so as not to } \\
\text { hinder group-wide supervision. The group-wide supervision framework should extend the } \\
\text { following legal entity requirements to the group level: solvency assessment, governance, risk } \\
\text { management, and market conduct. } \\
\text { It is noted that there is an ongoing effort to implement a framework of consolidated supervision } \\
\text { of financial conglomerates on a group-wide basis. While not finalized, the proposed framework }\end{array}$ \\
\hline
\end{tabular}

\section{CInternational Monetary Fund. Not for Redistribution}




\begin{tabular}{|c|c|}
\hline & $\begin{array}{l}\text { is based on a solo-plus model, consisting of (a) solo supervision of a financial institution and } \\
\text { its subsidiaries, plus (b) quantitative and qualitative assessment of the financial conglomerate } \\
\text { by the lead regulator to assess the potential impact of other members of the group, including } \\
\text { overseas subsidiaries or affiliates, on the operations of the supervised entity. The scope of the } \\
\text { quantitative assessment encompasses capital adequacy, intra-group transactions, large } \\
\text { exposures and connected lending, and ALM. Qualitative assessment includes structure of the } \\
\text { group and inherent risk, group corporate governance, risk management and internal controls, } \\
\text { and access to prudential information by different regulators. The framework contemplates } \\
\text { cross-border issues in consolidated supervision. }\end{array}$ \\
\hline ICP 24 & $\begin{array}{l}\text { Macroprudential Surveillance and Insurance Supervision } \\
\text { The supervisor identifies, monitors and analyses market and financial developments and other } \\
\text { environmental factors that may impact insurers and insurance markets and uses this } \\
\text { information in the supervision of individual insurers. Such tasks should, where appropriate, } \\
\text { utilise information from, and insights gained by, other national authorities. }\end{array}$ \\
\hline Description & $\begin{array}{l}\text { NAICOM monitors the economic environment in which the insurance sector operates and } \\
\text { collates insurance statistics to assess the impact of the economy on insurance sector growth } \\
\text { and vice versa. } \\
\text { NAICOM conducts market analysis using insurance statistics to monitor any emerging market } \\
\text { trends. It has published a publication NAICOM Watch for the first time in December } 2011 \text {. } \\
\text { NAICOM conducted a study of the impact of the recent divesture by banks on the insurance } \\
\text { sector. } \\
\text { It will conduct stakeholder perception surveys to gauge the public's opinion of the insurance } \\
\text { market and how NAICOM performs in } 2012 \text {. } \\
\text { The main focus is on increasing public awareness of insurance through surveys, workshops } \\
\text { and public education programs. }\end{array}$ \\
\hline Assessment & Partly observed \\
\hline Comments & $\begin{array}{l}\text { NAICOM should consider developing a macroprudential surveillance system, including } \\
\text { industry-wide stress tests to identify trends, potential risks and plausible future unfavourable } \\
\text { scenarios, so that it may take early action to reduce the likelihood of systemic risk. The } \\
\text { existing FSRCC forum is a natural mechanism for cooperation across the entire financial } \\
\text { sector. } \\
\text { In performing its macroprudential surveillance, NAICOM should use entity as well as group- } \\
\text { wide data to analyze and monitor potential impact on the financial stability of particular } \\
\text { insurers and the insurance market as a whole, and to assess whether financial market risks } \\
\text { impinge on prudential safeguards. } \\
\text { NAICOM should also establish a process to assess the potential systemic importance of } \\
\text { insurers, and to develop an appropriate supervisory response. }\end{array}$ \\
\hline ICP 25 & $\begin{array}{l}\text { Supervisory Cooperation and Coordination } \\
\text { The supervisor cooperates and coordinates with other relevant supervisors and authorities } \\
\text { subject to confidentiality requirements. }\end{array}$ \\
\hline Description & $\begin{array}{l}\text { At the national level, NAICOM is a member of the FSRCC, which meets quarterly to discuss } \\
\text { regulatory and supervisory coordination issues. Internationally, NAICOM has entered into one } \\
\text { MOU on information exchange. The absence of an MOU does not preclude NAICOM from } \\
\text { assessing requests for supervisory information on a case-by-case basis. (See ICP 3.) } \\
\text { The Nigerian insurance market is mainly domestic in nature. Presence of foreign insurers is } \\
\text { limited to five joint ventures, whose operations are not significant. Nine Nigerian insurers have } \\
\text { presence in other African countries. Their foreign operations are also not significant relative to }\end{array}$ \\
\hline
\end{tabular}




\begin{tabular}{|c|c|}
\hline & $\begin{array}{l}\text { their total premium income. Insurance legislation in Nigeria does not yet deal with issues of } \\
\text { group-wide supervision (see ICP 23). NAICOM has not participated in any cross-border } \\
\text { supervisory colleges. }\end{array}$ \\
\hline Assessment & Partly observed \\
\hline Comments & $\begin{array}{l}\text { While the cross-border insurance activity is currently small in scale, NAICOM should start } \\
\text { considering cross-border coordination matters. A practical starting point is to build on its MOU } \\
\text { with Ghana to include the process for the two supervisors to discuss and determine the need } \\
\text { for group-wide supervision and to agree on the designated group-wide supervisor. }\end{array}$ \\
\hline ICP 26 & $\begin{array}{l}\text { Cross-border Cooperation and Coordination on Crisis Management } \\
\text { The supervisor cooperates and coordinates with other relevant supervisors and authorities } \\
\text { such that a cross-border crisis involving a specific insurer can be managed effectively. }\end{array}$ \\
\hline Description & $\begin{array}{l}\text { NAICOM does not have any procedures on cross-border coordination on crisis management. } \\
\text { While the RM Guidelines require insurers to have business continuity plans, there is no } \\
\text { requirement for such plans to be tested. }\end{array}$ \\
\hline Assessment & Not observed \\
\hline Comments & $\begin{array}{l}\text { The Nigerian insurance sector is a small part of the financial sector with simple products and } \\
\text { not a strong international presence. Therefore cross-border coordination and crisis } \\
\text { management has not been a high priority issue. Nonetheless, NAICOM should work toward } \\
\text { establishing methodology in identifying SIFIs and protocol on cross-border coordination on } \\
\text { crisis management following the IAIS standards for this principle. }\end{array}$ \\
\hline
\end{tabular}

